Cochrane Database of Systematic Reviews

\title{
Interventions for the treatment of oral and oropharyngeal cancers: surgical treatment (Review)
}

Bulsara VM, Worthington HV, Glenny AM, Clarkson JE, Conway DI, Macluskey M

Bulsara VM, Worthington HV, Glenny AM, Clarkson JE, Conway DI, Macluskey M.

Interventions for the treatment of oral and oropharyngeal cancers: surgical treatment.

Cochrane Database of Systematic Reviews 2018, Issue 12. Art. No.: CD006205.

DOI: 10.1002/14651858.CD006205.pub4.

www.cochranelibrary.com

Interventions for the treatment of oral and oropharyngeal cancers: surgical treatment (Review) 
TABLE OF CONTENTS

HEADER 1

ABSTRACT

PLAIN LANGUAGE SUMMARY

SUMMARY OF FINDINGS

BACKGROUND

OBJECTIVES

METHODS

Figure 1.

RESULTS

Figure 2.

DISCUSSION

Figure 3.

AUTHORS' CONCLUSIONS

ACKNOWLEDGEMENTS

REFERENCES

CHARACTERISTICS OF STUDIES

DATA AND ANALYSES

Analysis 1.1. Comparison 1 Elective neck dissection (ND) versus therapeutic (delayed) neck dissection, Outcome 1 Total mortality (HR for overall survival).

Analysis 1.2. Comparison 1 Elective neck dissection (ND) versus therapeutic (delayed) neck dissection, Outcome 2 Total mortality.

Analysis 1.3. Comparison 1 Elective neck dissection (ND) versus therapeutic (delayed) neck dissection, Outcome 3 New disease, progression or mortality (HR for disease-free survival).

Analysis 1.4. Comparison 1 Elective neck dissection (ND) versus therapeutic (delayed) neck dissection, Outcome 4 New disease, progression or mortality.

Analysis 1.5. Comparison 1 Elective neck dissection (ND) versus therapeutic (delayed) neck dissection, Outcome 5 Locoregional recurrence.

Analysis 2.1. Comparison 2 Radical neck dissection (ND) versus selective neck dissection, Outcome 1 Total mortality (HR for overall survival).

Analysis 2.2. Comparison 2 Radical neck dissection (ND) versus selective neck dissection, Outcome 2 New disease, progression or mortality (HR for disease-free survival).

Analysis 2.3. Comparison 2 Radical neck dissection (ND) versus selective neck dissection, Outcome 3 Recurrence. .................

Analysis 3.1. Comparison 3 Surgery plus radiotherapy (RT) versus radiotherapy alone, Outcome 1 Total mortality (HR for overall survival).

Analysis 4.1. Comparison 4 Positron-emission tomography-computed tomography (PET-CT) versus planned neck dissection, Outcome 1 Total mortality (HR for overall survival).

ADDITIONAL TABLES

APPENDICES

WHAT'S NEW

HISTORY

CONTRIBUTIONS OF AUTHORS

DECLARATIONS OF INTEREST

SOURCES OF SUPPORT

DIFFERENCES BETWEEN PROTOCOL AND REVIEW

INDEX TERMS 
[Intervention Review]

\section{Interventions for the treatment of oral and oropharyngeal cancers: surgical treatment}

Vishal M Bulsara1, Helen V Worthington², Anne-Marie Glenny³, Janet E Clarkson², David I Conway4, Michaelina Macluskey 5

1School of Dentistry, The University of Western Australia, Nedlands, Australia. ${ }^{2}$ Cochrane Oral Health, Division of Dentistry, School of Medical Sciences, Faculty of Biology, Medicine and Health, The University of Manchester, Manchester, UK. ${ }^{3}$ Division of Dentistry, School of Medical Sciences, Faculty of Biology, Medicine and Health, The University of Manchester, Manchester, UK. ${ }^{4}$ Glasgow Dental School, University of Glasgow, Glasgow, UK. 5 Unit of Oral Surgery and Medicine, University of Dundee, Dundee, UK

Contact address: Helen V Worthington, Cochrane Oral Health, Division of Dentistry, School of Medical Sciences, Faculty of Biology, Medicine and Health, The University of Manchester, Coupland Building 3, Oxford Road, Manchester, M13 9PL, UK. helen.worthington@manchester.ac.uk.

Editorial group: Cochrane Oral Health Group.

Publication status and date: Edited (no change to conclusions), published in Issue 4, 2020.

Citation: Bulsara VM, Worthington HV, Glenny AM, Clarkson JE, Conway DI, Macluskey M. Interventions for the treatment of oral and oropharyngeal cancers: surgical treatment. Cochrane Database of Systematic Reviews 2018, Issue 12. Art. No.: CD006205. DOI: 10.1002/14651858.CD006205.pub4.

Copyright @ 2020 The Cochrane Collaboration. Published by John Wiley \& Sons, Ltd.

\section{A B S T R A C T}

\section{Background}

Surgery is an important part of the management of oral cavity cancer with regard to both the removal of the primary tumour and removal of lymph nodes in the neck. Surgery is less frequently used in oropharyngeal cancer. Surgery alone may be treatment for early-stage disease or surgery may be used in combination with radiotherapy, chemotherapy and immunotherapy/biotherapy. There is variation in the recommended timing and extent of surgery in the overall treatment regimens of people with these cancers. This is an update of a review originally published in 2007 and first updated in 2011.

\section{Objectives}

To determine which surgical treatment modalities for oral and oropharyngeal cancers result in increased overall survival, disease-free survival and locoregional control and reduced recurrence. To determine the implication of treatment modalities in terms of morbidity, quality of life, costs, hospital days of treatment, complications and harms.

\section{Search methods}

Cochrane Oral Health's Information Specialist searched the following databases: Cochrane Oral Health's Trials Register (to 20 December 2017), the Cochrane Central Register of Controlled Trials (CENTRAL; 2017, Issue 11), MEDLINE Ovid (1946 to 20 December 2017) and Embase Ovid (1980 to 20 December 2017). We searched the US National Institutes of Health Trials Registry (ClinicalTrials.gov) and the World Health Organization International Clinical Trials Registry Platform for ongoing trials. There were no restrictions on the language or date of publication.

\section{Selection criteria}

Randomised controlled trials where more than $50 \%$ of participants had primary tumours of the oral cavity or oropharynx, or where separate data could be extracted for these participants, and that compared two or more surgical treatment modalities, or surgery versus other treatment modalities. 


\section{Data collection and analysis}

Two or more review authors independently extracted data and assessed risk of bias. We contacted study authors for additional information as required. We collected adverse events data from included studies.

\section{Main results}

We identified five new trials in this update, bringing the total number of included trials to 12 (2300 participants; 2148 with cancers of the oral cavity). We assessed four trials at high risk of bias, and eight at unclear. None of the included trials compared different surgical approaches for the excision of the primary tumour. We grouped the trials into seven main comparisons.

Future research may change the findings as there is only very low-certainty evidence available for all results.

Five trials compared elective neck dissection (ND) with therapeutic (delayed) ND in participants with oral cavity cancer and clinically negative neck nodes, but differences in type of surgery and duration of follow-up made meta-analysis inappropriate in most cases. Four of these trials reported overall and disease-free survival. The meta-analyses of two trials found no evidence of either intervention leading to greater overall survival (hazard ratio (HR) $0.84,95 \%$ confidence interval $(\mathrm{Cl}) 0.41$ to $1.72 ; 571$ participants), or disease-free survival (HR $0.73,95 \% \mathrm{Cl} 0.25$ to $2.11 ; 571$ participants), but one trial found a benefit for elective supraomohyoid ND compared to therapeutic ND in overall survival (RR $0.40,95 \% \mathrm{Cl} 0.19$ to $0.84 ; 67$ participants) and disease-free survival (HR $0.32,95 \% \mathrm{Cl} 0.12$ to $0.84 ; 67$ participants). Four individual trials assessed locoregional recurrence, but could not be meta-analysed; one trial favoured elective ND over therapeutic delayed $\mathrm{ND}$, while the others were inconclusive.

Two trials compared elective radical ND with elective selective ND, but we were unable to pool the data for two outcomes. Neither study found evidence of a difference in overall survival or disease-free survival. A single trial found no evidence of a difference in recurrence.

One trial compared surgery plus radiotherapy with radiotherapy alone, but data were unreliable because the trial stopped early and there were multiple protocol violations.

One trial comparing positron-emission tomography-computed tomography (PET-CT) following chemoradiotherapy (with ND only if no or incomplete response) versus planned ND (either before or after chemoradiotherapy), showed no evidence of a difference in mortality (HR $0.92,95 \% \mathrm{Cl} 0.65$ to $1.31 ; 564$ participants). The trial did not provide usable data for the other outcomes.

Three single trials compared: surgery plus adjunctive radiotherapy versus chemoradiotherapy; supraomohyoid ND versus modified radical ND; and super selective ND versus selective ND. There were no useable data from these trials.

The reporting of adverse events was poor. Four trials measured adverse events. Only one of the trials reported quality of life as an outcome.

\section{Authors' conclusions}

Twelve randomised controlled trials evaluated ND surgery in people with oral cavity cancers; however, the evidence available for all comparisons and outcomes is very low certainty, therefore we cannot rely on the findings. The evidence is insufficient to draw conclusions about elective ND of clinically negative neck nodes at the time of removal of the primary tumour compared to therapeutic (delayed) ND. Two trials combined in meta-analysis suggested there is no difference between these interventions, while one trial (which evaluated elective supraomohyoid ND) found that it may be associated with increased overall and disease-free survival. One trial found elective ND reduced locoregional recurrence, while three were inconclusive. There is no evidence that radical ND increases overall or diseasefree survival compared to more conservative ND surgery, or that there is a difference in mortality between PET-CT surveillance following chemoradiotherapy versus planned ND (before or after chemoradiotherapy). Reporting of adverse events in all trials was poor and it was not possible to compare the quality of life of people undergoing different surgical treatments.

\section{PLAIN LANGUAGE SUMMARY}

\section{Surgical treatments for oral cavity (mouth) and oropharyngeal (throat) cancers}

\section{Review question}

We evaluated clinical trials of surgical treatments for oral and oropharyngeal cancers to find out which were most likely to result in people with these cancers living longer (overall survival). living longer without symptoms (disease-free survival), and not experiencing a recurrence of the cancer at the same site or spread to other sites. We also wanted to find out how different treatments affect disease symptoms, quality of life, time in hospital, complications, side effects and cost.

\section{Background}

Oral cancer is among the most common cancers worldwide, with more than 400,000 new cases diagnosed in 2012. The treatment of these cancers can involve surgery, chemotherapy, radiotherapy, or a combination of two or all three therapies. This topic area was identified as a priority by an expert working group for oral and maxillofacial surgery in 2014. Authors working with Cochrane Oral Health conducted this review, which is an update of a review originally published in 2007 and first updated in 2011. The evidence is current to 20 December 2017. 


\section{Study characteristics}

We included 12 trials (five new for this update) that investigated the success of surgical treatment for oral cancers. The studies involved 2300 participants, 2148 of whom had mouth cancers. The trials included seven comparisons of different treatment options. None of them compared different surgical approaches for cutting out the primary tumour.

\section{Key results}

The findings of the studies are mixed and it is not possible to draw firm conclusions about the optimal surgical approach for mouth and throat cancers.

Surgical removal of the lymph nodes in the neck that appear to be cancer-free, at the same time as the cancer is removed did not seem to be associated with longer survival in two studies whose results were combined. Another study, however, suggested there may be a benefit of early neck surgery in terms of overall survival and 'disease-free survival' (length of time after primary treatment without signs and symptoms of disease). One study found cancer recurrence at or around the same site was less likely with the early surgery, while three other studies did not favour either treatment.

There was no evidence that removal of all the lymph nodes in the neck resulted in longer survival compared to selective surgical removal of affected lymph nodes.

One study evaluated use of a special scan (positron-emission tomography-computed tomography (PET-CT)), after a combination of chemotherapy and radiotherapy, to guide decisions about neck dissection, and found no difference in mortality (death) compared with undertaking a planned neck dissection before or after chemoradiotherapy.

There were a number of other surgical approaches compared in the studies, but we were unable to use the results in this review.

Although removal of lymph nodes from the neck is known to be associated with significant negative effects related to appearance and functions such as eating, drinking and speaking, the studies reported poorly on these side effects and did not measure quality of life accurately enough or in large enough numbers to be included in any of our analyses.

\section{Certainty of the evidence}

The certainty of the evidence was very low as there were few studies for each comparison and they were at risk of bias because of the way they were designed. Some comparisons and outcomes had no useable results. 


\section{SUMMARY OF FINDINGS}

\section{Summary of findings for the main comparison. Elective neck dissection versus therapeutic (delayed) neck dissection}

Elective neck dissection versus therapeutic (delayed) neck dissection

Patient: adults with oral or oropharyngeal cancer

Setting: inpatient

Intervention: elective neck dissection

Comparison: therapeutic (delayed) neck dissection

\begin{tabular}{|c|c|c|c|c|c|c|}
\hline \multirow[t]{3}{*}{ Outcomes } & \multicolumn{2}{|c|}{$\begin{array}{l}\text { Illustrative comparative risks }{ }^{\star} \\
(95 \% \mathrm{CI})\end{array}$} & \multirow{3}{*}{$\begin{array}{l}\text { Relative ef- } \\
\text { fect } \\
(95 \% \mathrm{CI})\end{array}$} & \multirow{3}{*}{$\begin{array}{l}\text { Number of } \\
\text { participants } \\
\text { (studies) }\end{array}$} & \multirow{3}{*}{$\begin{array}{l}\text { Certainty of } \\
\text { the evidence } \\
\text { (GRADE) }\end{array}$} & \multirow[t]{3}{*}{ Comments } \\
\hline & Assumed risk & $\begin{array}{l}\text { Corresponding } \\
\text { risk }\end{array}$ & & & & \\
\hline & $\begin{array}{l}\text { Therapeutic } \\
\text { neck dissec- } \\
\text { tion }\end{array}$ & $\begin{array}{l}\text { Elective neck } \\
\text { dissection }\end{array}$ & & & & \\
\hline $\begin{array}{l}\text { Total mortal- } \\
\text { ity } \\
\text { (follow-up: } 3 \\
\text { years) }\end{array}$ & $500^{a}$ per 1000 & $\begin{array}{l}441 \text { per } 1000(247 \\
\text { to } 696)\end{array}$ & $\begin{array}{l}\text { HR } 0.84 \\
(0.41 \text { to } 1.72)\end{array}$ & $\begin{array}{l}571 \\
(2)\end{array}$ & $\begin{array}{l}\oplus \ominus \ominus \ominus \\
\text { Very low } b, c, d\end{array}$ & $\begin{array}{l}\text { These data were from the HR for overall survival. } \\
\text { Other binary data from } 2 \text { trials could not be pooled. } 1 \text { trial indi- } \\
\text { cated no clear evidence of either intervention leading to lower } \\
\text { mortality; however, } 1 \text { small trial indicated elective neck dissec- } \\
\text { tion led to lower mortality (RR } 0.40,95 \% \mathrm{Cl} 0.19 \text { to } 0.84 \text { ) (very } \\
\text { low-certainty evidence). }\end{array}$ \\
\hline \multirow{2}{*}{$\begin{array}{l}\text { New disease, } \\
\text { progression } \\
\text { or mortality } \\
\text { (follow-up: } 3 \\
\text { years) }\end{array}$} & 500 e per 1000 & $\begin{array}{l}397.1 \text { per } 1000 \\
(159 \text { to } 768)\end{array}$ & \multirow[t]{2}{*}{$\begin{array}{l}\text { HR } 0.73 \\
(0.25 \text { to } 2.11)\end{array}$} & \multirow[t]{2}{*}{$\begin{array}{l}571 \\
(2)\end{array}$} & \multirow[t]{2}{*}{$\begin{array}{l}\oplus \ominus \ominus \ominus \\
\text { Very lowb,c }\end{array}$} & \multirow{2}{*}{$\begin{array}{l}\text { These data were from the HR for disease-free survival. } \\
\text { Binary data from } 2 \text { trials did not favour either intervention. } 1 \\
\text { trial provided some very low-certainty evidence for elective } \\
\text { SOH leading to lower mortality (HR } 0.32,95 \% \mathrm{Cl} 0.12 \text { to } 0.84 \text { ). }\end{array}$} \\
\hline & $250^{e}$ per 1000 & $\begin{array}{l}190 \text { per } 1000(69 \\
\text { to } 455)\end{array}$ & & & & \\
\hline $\begin{array}{l}\text { Locoregional } \\
\text { recurrence }\end{array}$ & - & - & - & $\begin{array}{l}278 \\
(4)\end{array}$ & $\begin{array}{l}\oplus \ominus \ominus \ominus \\
\text { Very lowc,f }\end{array}$ & $\begin{array}{l}\text { Binary data; unable to pool data (different timings). Three stud- } \\
\text { ies were inconclusive and one favoured elective procedure. }\end{array}$ \\
\hline Recurrence & - & - & - & 0 & - & No data presented \\
\hline
\end{tabular}




\begin{tabular}{ll}
\hline $\begin{array}{l}\text { Adverse } \\
\text { events }\end{array}$ & $\begin{array}{l}1 \text { study showed that } 6.6 \% \text { of elective-surgery participants reported adverse events, while 3.6\% of participants in therapeutic-surgery group reported ad- } \\
\text { verse events. These adverse events included: neck haematoma, chyle leak, oral bleeding, postoperative infection and anaphylaxis. None of the other trials } \\
\text { reported on adverse events. }\end{array}$
\end{tabular}

${ }^{*}$ The basis for the assumed risk (e.g. the median control group risk across studies) is provided in footnotes. The corresponding risk (and its $95 \%$ confidence interval) is based on the assumed risk in the comparison group and the relative effect of the intervention (and its $95 \% \mathrm{Cl}$ ).

Cl: confidence interval; HR: hazard ratio; RR: risk ratio; SOH: supraomohyoid neck dissection.

\section{GRADE Working Group grades of evidence}

High certainty: we are very confident that the true effect lies close to that of the estimate of the effect.

Moderate certainty: we are moderately confident in the effect estimate; the true effect is likely to be close to the estimate of the effect, but there is a possibility that it is substantially different.

Low certainty: our confidence in the effect estimate is limited; the true effect may be substantially different from the estimate of the effect.

Very low certainty: we have very little confidence in the effect estimate; the true effect is likely to be substantially different from the estimate of effect.

aBased on data presented by Warnakulasuriya 2009.

$b$ Downgraded once as two trials at unclear risk of bias.

cDowngraded twice for imprecision.

dDowngraded once for heterogeneity.

epurely illustrative, unable to find any epidemiological estimates.

fDowngraded once for study design; four heterogeneous trials, two at high risk of bias and two at unclear risk of bias.

\section{Summary of findings 2 . Elective radical neck dissection versus elective selective neck dissection}

\section{Radical neck dissection versus selective neck dissection}

Patient: adults with oral or oropharyngeal cancer

\section{Setting: inpatient}

Intervention: elective radical neck dissection

Comparison: elective selective neck dissection

\begin{tabular}{|c|c|c|c|c|c|c|}
\hline \multirow[t]{3}{*}{ Outcomes } & \multicolumn{2}{|c|}{ Illustrative comparative risks* $(95 \% \mathrm{CI})$} & \multirow{3}{*}{$\begin{array}{l}\text { Relative effect } \\
(95 \% \mathrm{Cl})\end{array}$} & \multirow{3}{*}{$\begin{array}{l}\text { Number of } \\
\text { participants } \\
\text { (studies) }\end{array}$} & \multirow{3}{*}{$\begin{array}{l}\text { Certainty of the } \\
\text { evidence } \\
\text { (GRADE) }\end{array}$} & \multirow[t]{3}{*}{ Comments } \\
\hline & Assumed risk & Corresponding risk & & & & \\
\hline & $\begin{array}{l}\text { Selective neck dis- } \\
\text { section }\end{array}$ & $\begin{array}{l}\text { Radical neck dissec- } \\
\text { tion }\end{array}$ & & & & \\
\hline
\end{tabular}




\begin{tabular}{|c|c|c|c|c|c|c|}
\hline & - & - & - & $\begin{array}{l}252 \\
(2)\end{array}$ & $\begin{array}{l}\oplus \ominus \ominus \ominus \\
\text { Very lowa,b }\end{array}$ & $\begin{array}{l}\text { HR from } 2 \text { trials, but unable to pool data as dif- } \\
\text { ferent surgical procedures. Neither trial indicat- } \\
\text { ed that mortality was different for the } 2 \text { inter- } \\
\text { ventions. }\end{array}$ \\
\hline $\begin{array}{l}\text { New disease, } \\
\text { progression } \\
\text { or mortality }\end{array}$ & $500^{C}$ per 1000 & $\begin{array}{l}326 \text { per } 1000 \\
(182 \text { to } 537)\end{array}$ & \multirow[t]{2}{*}{$\begin{array}{l}\text { HR } 0.57 \\
\text { (0.29 to } 1.11)\end{array}$} & \multirow[t]{2}{*}{$\begin{array}{l}104 \\
(1)\end{array}$} & \multirow[t]{2}{*}{$\begin{array}{l}\oplus \ominus \ominus \ominus \\
\text { Very lowb,d }\end{array}$} & \multirow{2}{*}{$\begin{array}{l}\text { These data were from the HR for disease-free } \\
\text { survival. } \\
1 \text { study, indicating no difference between the } \\
\text { interventions. }\end{array}$} \\
\hline $\begin{array}{l}\text { (follow-up: } 5 \\
\text { years) }\end{array}$ & $250^{c}$ per 1000 & $\begin{array}{l}151 \text { per } 1000 \text { ( } 80 \text { to } \\
273)\end{array}$ & & & & \\
\hline $\begin{array}{l}\text { Locoregional } \\
\text { recurrence }\end{array}$ & - & - & - & - & - & Not reported \\
\hline $\begin{array}{l}\text { Recurrence } \\
\text { (5 years) }\end{array}$ & $180^{e}$ per 1000 & $\begin{array}{l}213 \text { per } 1000 \\
(118 \text { to } 370)\end{array}$ & $\begin{array}{l}\text { RR } 1.21 \\
\text { (0.63 to } 2.33 \text { ) }\end{array}$ & $\begin{array}{l}143 \\
(1)\end{array}$ & $\begin{array}{l}\oplus \ominus \ominus \ominus \\
\text { Very lowb,f,g }\end{array}$ & $\begin{array}{l}1 \text { study, indicating no difference between the } \\
\text { interventions. }\end{array}$ \\
\hline $\begin{array}{l}\text { Adverse } \\
\text { events }\end{array}$ & \multicolumn{6}{|c|}{$\begin{array}{l}1 \text { trial reported the following adverse effects: flap necrosis, wound infection, fistula, vascular rupture, haematoma, seroma and chyle fistula. There were } \\
0 \text { complications in } 45 \text { participants ( } 59 \%) \text { in the modified radical neck dissection group and } 0 \text { in } 54 \text { participants ( } 75 \%) \text { in the supraomohyoid neck dissec- } \\
\text { tion group. There were } 2 \text { postoperative deaths in the modified radical neck dissection group and } 1 \text { in the supraomohyoid neck dissection group. The other } \\
\text { studies did not report adverse events }\end{array}$} \\
\hline
\end{tabular}

${ }^{*}$ The basis for the assumed risk (e.g. the median control group risk across studies) is provided in footnotes. The corresponding risk (and its $95 \%$ confidence interval) is based on the assumed risk in the comparison group and the relative effect of the intervention (and its $95 \% \mathrm{Cl}$ ).

Cl: confidence interval; HR: hazard ratio; RR: risk ratio.

\section{GRADE Working Group grades of evidence}

High certainty: we are very confident that the true effect lies close to that of the estimate of the effect.

Moderate certainty: we are moderately confident in the effect estimate; the true effect is likely to be close to the estimate of the effect, but there is a possibility that it is substantially different.

Low certainty: our confidence in the effect estimate is limited; the true effect may be substantially different from the estimate of the effect.

Very low certainty: we have very little confidence in the effect estimate; the true effect is likely to be substantially different from the estimate of effect.

aDowngraded twice, two heterogeneous studies at unclear and high risk of bias.

${ }^{b}$ Downgraded once for imprecision.

cPurely illustrative, unable to find any epidemiological estimates.

$d$ Downgraded twice as single study at high risk of bias.

eEstimated from BHNCSG 1998.

fSDowngraded once as single study at unclear risk of bias.

$g$ Downgraded twice for imprecision 


\begin{tabular}{|c|c|c|c|c|c|c|}
\hline \multicolumn{7}{|c|}{ Surgery plus radiotherapy versus radiotherapy alone } \\
\hline \multirow{4}{*}{\multicolumn{7}{|c|}{$\begin{array}{l}\text { Patient: adults with oral or oropharyngeal cancer } \\
\text { Setting: inpatient } \\
\text { Intervention: surgery + radiotherapy } \\
\text { Comparison: radiotherapy alone }\end{array}$}} \\
\hline & & & & & & \\
\hline & & & & & & \\
\hline & & & & & & \\
\hline \multirow[t]{3}{*}{ Outcomes } & \multicolumn{2}{|c|}{ Illustrative comparative risks* $(95 \% \mathrm{CI})$} & \multirow{3}{*}{$\begin{array}{l}\text { Relative effect } \\
(95 \% \mathrm{Cl})\end{array}$} & \multirow{3}{*}{$\begin{array}{l}\text { Number of } \\
\text { participants } \\
\text { (studies) }\end{array}$} & \multirow{3}{*}{$\begin{array}{l}\text { Certainty of } \\
\text { the evidence } \\
\text { (GRADE) }\end{array}$} & \multirow[t]{3}{*}{ Comments } \\
\hline & Assumed risk & Corresponding risk & & & & \\
\hline & $\begin{array}{l}\text { Radiotherapy } \\
\text { alone }\end{array}$ & $\begin{array}{l}\text { Surgery + radiothera- } \\
\text { py }\end{array}$ & & & & \\
\hline $\begin{array}{l}\text { Total mortality } \\
\text { (follow-up: } 3 \\
\text { years) }\end{array}$ & 500 per 1000 & $\begin{array}{l}153 \text { per } 1000 \\
(67 \text { to } 336)\end{array}$ & $\begin{array}{l}\text { HR } 0.24 \\
(0.10 \text { to } 0.59)\end{array}$ & $\begin{array}{l}35 \\
(1)\end{array}$ & $\begin{array}{l}\oplus \ominus \odot \odot \\
\text { Very low } a\end{array}$ & $\begin{array}{l}\text { These data were from the HR for overall survival. } \\
1 \text { study, result favouring the surgery group; how- } \\
\text { ever, data were unreliable because trial stopped } \\
\text { early and there were multiple protocol viola- } \\
\text { tions. }\end{array}$ \\
\hline $\begin{array}{l}\text { Disease-free } \\
\text { survival }\end{array}$ & - & - & - & - & - & Not reported \\
\hline $\begin{array}{l}\text { Locoregional } \\
\text { recurrence }\end{array}$ & - & - & - & - & - & Not reported \\
\hline Recurrence & - & - & - & - & - & Not reported \\
\hline Adverse events & \multicolumn{6}{|c|}{$\begin{array}{l}\text { Both groups reported the following severe acute adverse effects: subcutaneous fibrosis, telangiectasia }\left(1-4 \mathrm{~cm}^{2}\right) \text {, and moderate-to-severe oedema, xe- } \\
\text { rostomia, trismus and dysphagia. Subcutaneous fibrosis was reported as more prevalent in the surgery + radiotherapy group }(P=0.042) \text {, but the preva- } \\
\text { lence of other adverse effects appeared to be similar in each group. }\end{array}$} \\
\hline
\end{tabular}

${ }^{*}$ The basis for the assumed risk (e.g. the median control group risk across studies) is provided in footnotes. The corresponding risk (and its $95 \%$ confidence interval) is based on the assumed risk in the comparison group and the relative effect of the intervention (and its $95 \% \mathrm{Cl}$ ).

Cl: confidence interval; HR: hazard ratio.

GRADE Working Group grades of evidence

High certainty: we are very confident that the true effect lies close to that of the estimate of the effect. 
Moderate certainty: we are moderately confident in the effect estimate; the true effect is likely to be close to the estimate of the effect, but there is a possibility that it is substantially different.

Low certainty: our confidence in the effect estimate is limited; the true effect may be substantially different from the estimate of the effect.

Very low certainty: we have very little confidence in the effect estimate; the true effect is likely to be substantially different from the estimate of effect.

aDowngraded three levels as high risk of bias, interim analysis of 35 participants after 23 months.

Summary of findings 4. PET-CT following chemoradiotherapy versus planned neck dissection either before or after chemoradiotherapy

PET-CT following chemoradiotherapy versus planned neck dissection either before or after chemoradiotherapy

Patient: adults with oral or oropharyngeal cancer

Setting: inpatient

Intervention: PET-CT following chemoradiotherapy

Comparison: planned neck dissection either before or after chemoradiotherapy

\begin{tabular}{|c|c|c|c|c|c|c|}
\hline \multirow[t]{3}{*}{ Outcomes } & \multicolumn{2}{|c|}{$\begin{array}{l}\text { Illustrative comparative risks* }(95 \% \\
\mathrm{Cl} \text { ) }\end{array}$} & \multirow{3}{*}{$\begin{array}{l}\text { Relative ef- } \\
\text { fect } \\
(95 \% \mathrm{Cl})\end{array}$} & \multirow{3}{*}{$\begin{array}{l}\text { No of partici- } \\
\text { pants } \\
\text { (studies) }\end{array}$} & \multirow{3}{*}{$\begin{array}{l}\text { Certainty of } \\
\text { the evidence } \\
\text { (GRADE) }\end{array}$} & \multirow[t]{3}{*}{ Comments } \\
\hline & Assumed risk & $\begin{array}{l}\text { Corresponding } \\
\text { risk }\end{array}$ & & & & \\
\hline & $\begin{array}{l}\text { Planned neck } \\
\text { dissection }\end{array}$ & PET-CT & & & & \\
\hline Disease-free survival & - & - & - & - & - & Outcome not reported in a usable way. \\
\hline $\begin{array}{l}\text { Locoregional recur- } \\
\text { rence }\end{array}$ & - & - & - & - & - & Outcome not reported in a usable way. \\
\hline Recurrence & - & - & - & - & - & Outcome not reported in a usable way. \\
\hline Adverse events & \multicolumn{6}{|c|}{22 surgical complications in PET-CT group compared with 83 in planned surgery group. } \\
\hline
\end{tabular}

*The basis for the assumed risk (e.g. the median control group risk across studies) is provided in footnotes. The corresponding risk (and its $95 \%$ confidence interval) is based on the assumed risk in the comparison group and the relative effect of the intervention (and its $95 \% \mathrm{Cl}$ ). 


\begin{tabular}{|c|c|c|c|c|c|c|}
\hline \multicolumn{7}{|c|}{$\begin{array}{l}\text { GRADE Working Group grades of evidence } \\
\text { High certainty: we are very confident that the true effect lies close to that of the estimate of the effect. } \\
\text { Moderate certainty: we are moderately confident in the effect estimate; the true effect is likely to be close to the estimate of the effect, but there is a possibility that it is } \\
\text { substantially different. } \\
\text { Low certainty: our confidence in the effect estimate is limited; the true effect may be substantially different from the estimate of the effect. } \\
\text { Very low certainty: we have very little confidence in the effect estimate; the true effect is likely to be substantially different from the estimate of effect. }\end{array}$} \\
\hline $\begin{array}{l}\text { Downgraded once as } \\
\text { Downgraded twice } f \\
\text { Summary of findin }\end{array}$ & $\begin{array}{l}\text { e study at unclear } \\
\text { aprecision. } \\
\text { 5. Surgery plu. }\end{array}$ & $\begin{array}{l}\text { isk of bias. } \\
\text { adjuvant radioth }\end{array}$ & rapy versus & emotherapy & & \\
\hline \multicolumn{7}{|c|}{ Surgery plus adjuvant radiotherapy versus chemotherapy } \\
\hline \multicolumn{7}{|c|}{$\begin{array}{l}\text { Patient: adults with oral or oropharyngeal cancer } \\
\text { Setting: inpatient } \\
\text { Intervention: surgery + adjuvant radiotherapy } \\
\text { Comparison: chemotherapy }\end{array}$} \\
\hline \multirow[t]{3}{*}{ Outcomes } & \multicolumn{2}{|c|}{$\begin{array}{l}\text { Illustrative comparative risks* } \\
(95 \% \mathrm{Cl})\end{array}$} & \multirow{3}{*}{$\begin{array}{l}\text { Relative ef- } \\
\text { fect } \\
(95 \% \mathrm{CI})\end{array}$} & \multirow{3}{*}{$\begin{array}{l}\text { Number of } \\
\text { participants } \\
\text { (studies) }\end{array}$} & \multirow{3}{*}{$\begin{array}{l}\text { Certainty of } \\
\text { the evidence } \\
\text { (GRADE) }\end{array}$} & \multirow[t]{3}{*}{ Comments } \\
\hline & Assumed risk & $\begin{array}{l}\text { Corresponding } \\
\text { risk }\end{array}$ & & & & \\
\hline & Chemotherapy & $\begin{array}{l}\text { Surgery + adju- } \\
\text { vant radiothera- } \\
\text { py }\end{array}$ & & & & \\
\hline $\begin{array}{l}\text { Total mortality } \\
\text { (follow-up: } 2 \text { years) }\end{array}$ & - & - & - & - & - & $\begin{array}{l}1 \text { study report stated, "For the oral } \\
\text { cavity, survival was significantly } \\
\text { better in patients who underwent } \\
\text { surgery and RT compared with the CRT } \\
\text { [chemoradiotherapy] group." Howev- } \\
\text { er, there were no useable data. }\end{array}$ \\
\hline $\begin{array}{l}\text { Disease-free sur- } \\
\text { vival }\end{array}$ & - & - & - & - & - & $\begin{array}{l}\text { Reported as statistically significant in } \\
\text { favour of the surgery group }(P=0.038) \text {, } \\
\text { but there were no useable data. }\end{array}$ \\
\hline
\end{tabular}




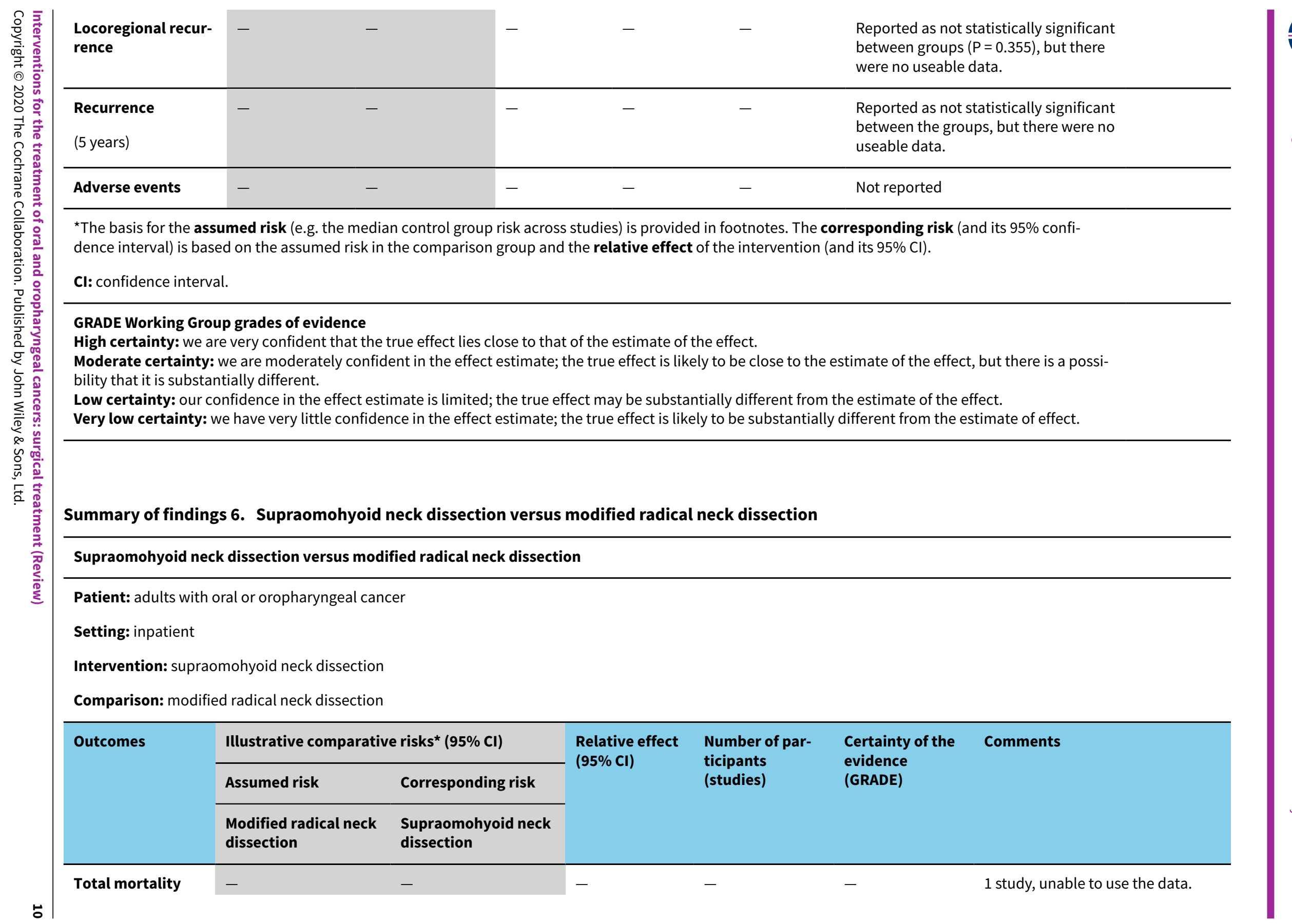




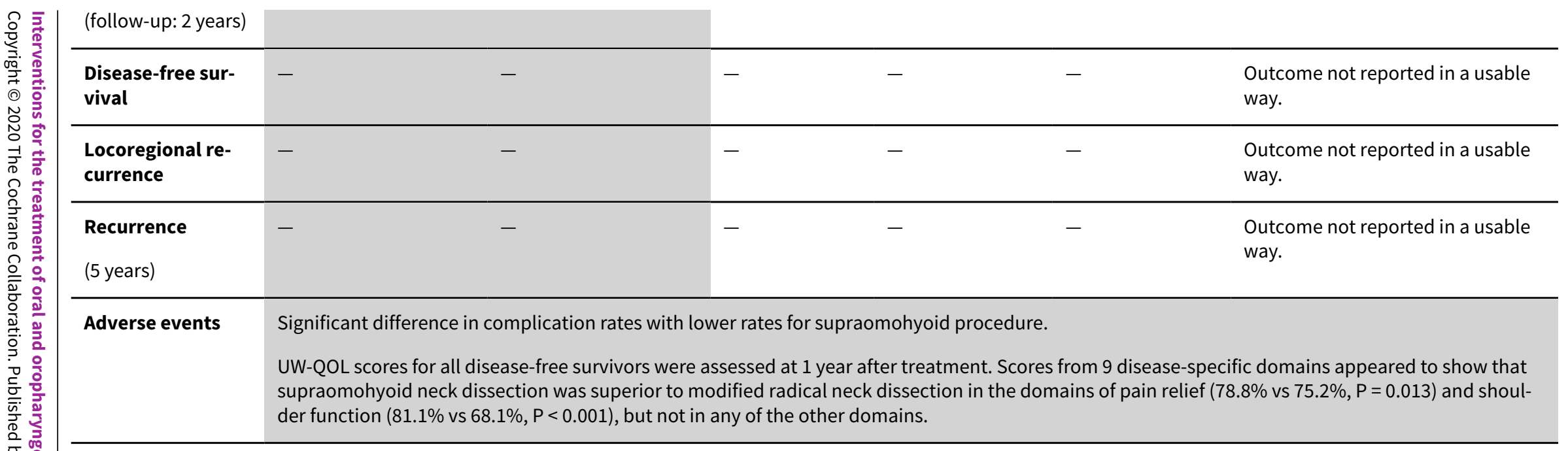

\section{GRADE Working Group grades of evidence}

High certainty: we are very confident that the true effect lies close to that of the estimate of the effect.

Moderate certainty: we are moderately confident in the effect estimate; the true effect is likely to be close to the estimate of the effect, but there is a possibility that it is substantially different.

Low certainty: our confidence in the effect estimate is limited; the true effect may be substantially different from the estimate of the effect.

Very low certainty: we have very little confidence in the effect estimate; the true effect is likely to be substantially different from the estimate of effect.

Cl: confidence interval; UW-QOL: University of Washington Quality of Life Questionnaire.

\section{Summary of findings 7 . Super-selective neck dissection versus selective neck dissection}

\section{Super-selective neck dissection versus selective neck dissection}

Patient: adults with oral or oropharyngeal cancer

\section{Setting: inpatient}

Intervention: super-selective neck dissection

Comparison: selective neck dissection

\begin{tabular}{|c|c|c|c|c|c|c|}
\hline \multirow[t]{2}{*}{ Outcomes } & Illustrative co & rative risks ${ }^{\star}(95 \% \mathrm{Cl})$ & \multirow{2}{*}{$\begin{array}{l}\text { Relative ef- } \\
\text { fect } \\
(95 \% \mathrm{CI})\end{array}$} & \multirow{2}{*}{$\begin{array}{l}\text { Number of } \\
\text { participants } \\
\text { (studies) }\end{array}$} & \multirow{2}{*}{$\begin{array}{l}\text { Certainty of } \\
\text { the evidence } \\
\text { (GRADE) }\end{array}$} & \multirow[t]{2}{*}{ Comments } \\
\hline & Assumed risk & Corresponding risk & & & & \\
\hline
\end{tabular}




\begin{tabular}{|c|c|c|c|c|c|c|}
\hline & $\begin{array}{l}\text { Selective neck } \\
\text { dissection }\end{array}$ & $\begin{array}{l}\text { Super-selective } \\
\text { neck dissection }\end{array}$ & & & & \\
\hline $\begin{array}{l}\text { Total mortality } \\
\text { (follow-up: } 2 \text { years) }\end{array}$ & - & - & - & - & - & Outcome not reported \\
\hline Disease-free survival & - & - & - & - & - & Outcome not reported \\
\hline Locoregional recurrence & - & - & - & - & - & $\begin{array}{l}\text { Data not presented in a useable way. Re- } \\
\text { port concluded that super-selective pro- } \\
\text { cedure showed a lower rate of recurrence. }\end{array}$ \\
\hline $\begin{array}{l}\text { Recurrence } \\
\text { (5 years) }\end{array}$ & - & - & - & - & - & Outcome not reported in a usable way. \\
\hline Adverse events & \multicolumn{6}{|c|}{ Shoulder morbidity data indicated improvement for super-selective group, as well as better quality of life. } \\
\hline
\end{tabular}

\section{GRADE Working Group grades of evidence}

High certainty: we are very confident that the true effect lies close to that of the estimate of the effect.

Moderate certainty: we are moderately confident in the effect estimate; the true effect is likely to be close to the estimate of the effect, but there is a possibility that it is substantially different.

Low certainty: our confidence in the effect estimate is limited; the true effect may be substantially different from the estimate of the effect.

Very low certainty: we have very little confidence in the effect estimate; the true effect is likely to be substantially different from the estimate of effect. 


\section{B A C K G R O U N D}

\section{Description of the condition}

Head and neck cancers (HNC) comprise laryngeal, pharyngeal and oral cancers. Collectively, they are the sixth most common cancer in the world, accounting for approximately $5 \%$ of all malignant tumours (Torre 2015). HNC generally have common risk factors and aetiology (Winn 2015); however, since the late 2000s, oropharyngeal (throat) cancers have increasingly been associated with human papillomavirus (HPV), unlike other oral cancers (D'Souza 2007). The tumours do not always recognise the boundaries between the oral cavity and oropharynx, with tumours frequently overlapping these sites (Tapia 2011).

HNCs are increasingly treated by multidisciplinary HNC teams in centralised units (Hughes 2012; Lo Nigro 2017). Clinical trials have generally recruited people with HNCs as if this was a single disease entity (Adelstein 2009). This influences the evidence base available to draw from in a systematic review.

Oral cancer (defined here to include both oral cavity and oropharynx cancers) is among the most common cancers worldwide, with approximately 442,760 incident cases and 241,418 deaths reported in 2012 (Ferlay 2013; Stewart 2014). There are geographical variations in the incidence of oral cancers, with increase among men and women in some European countries, stabilisation in certain Asian countries, and decrease in Canada and USA (Chaturvedi 2013; Simard 2014). In the UK, incidence trends are continuing to rise, driven mainly by oropharyngeal cancer rates (Louie 2015; Purkayastha 2016). Survival following a diagnosis of oral cavity or oropharyngeal cancer remains poor with five-year survival around $50 \%$ overall, with only limited improvement since the late 1980s (Warnakulasuriya 2009).

There is overwhelming evidence that tobacco use, alcohol consumption and betel quid chewing are the main risk factors in the aetiology of oral cancer (Gupta 2014; La Vecchia 1997; Macfarlane 1995; Winn 2015). There is also strong evidence that low socioeconomic status (educational attainment and income) is associated with substantial increased risk not explained by tobacco and alcohol (Conway 2015). There is a higher incidence of oral cancers among men (Freedman 2007), and the vast majority of cases occur in men over 50 years of age (Warnakulasuriya 2009), and among low socioeconomic groups (Conway 2008). However, the ratio of males to females diagnosed with oral cancers has changed from approximately 5:1 in the 1960s to less than 2:1 after 2000 (Parkin 2005; Purkayastha 2016).

Two distinct types of oropharyngeal cancer exist as classified according to HPV status. HPV-negative oropharyngeal cancer is epidemiologically similar to the traditional type of cancer of the upper aerodigestive tract, in which long-term exposure to tobacco and alcohol products leads to development of malignancy. HPV-positive oropharyngeal cancer starts with exposure to highrisk HPV, most often HPV 16, and can develop independently of tobacco or alcohol exposure (Gillison 2000). People with HPVpositive oropharyngeal cancer are more likely to be male and of a relatively younger age than their HPV-negative counterparts (Chaturvedi 2008; Chaturvedi 2015; Gillison 2007). Moreover, they have a better overall performance and are less likely to be smokers or heavy alcohol consumers (Gillison 2000). In the US, it is suggested that more the $70 \%$ of oropharyngeal cancers are HPV positive (Chaturvedi 2011).

The link between oncogenic HPV and oropharyngeal cancer is strong and has been documented in numerous studies, fulfilling the epidemiological criteria for disease causality, especially in the development of oropharyngeal cancer in non-smokers (Sturgis 2007). Since the early 1990s, the proportion of people with oropharyngeal cancer who are HPV positive has increased dramatically (Attner 2010; Ryerson 2008), but it is interesting to note that this group of people have significantly improved rates of both overall survival and disease-free survival (Adelstein 2009; Fakhry 2006; Fakhry 2008; Licitra 2006), and more recent trials are beginning to treat HPV-positive oropharyngeal cancers differently (Blanchard 2011; Holsinger 2015; Parsons 2002). There is evidence to suggest that the rate of oral cavity cancer has reached a plateau, whereas the proportion of people developing oropharyngeal cancer is increasing and is projected to continue to increase (Purkayastha 2016).

\section{Description of the intervention}

Surgery can be combined with one or more other treatments, that is, radiotherapy, chemotherapy and immunotherapy/ biotherapy; the sequence of these combination therapies is considered important. Radiotherapy is typically now administered postoperatively. Chemotherapy can be given: 1 . before surgery (induction/neoadjuvant - when treatment is administered before the primary therapy, e.g. to shrink a tumour prior to surgery or radiation); 2. after surgery (adjuvant - administered after the primary therapy, e.g. when the primary therapy to treat a cancerous tumour is surgery, chemotherapy would be considered an adjuvant therapy) and before radiotherapy; 3 . at the same time as radiotherapy (concomitant/concurrent - it may also be referred to as chemoradiotherapy); or 4. alternating with radiotherapy. In recent years, a form of radiotherapy called intensity-modulated radiotherapy (IMRT) has been used to treat oral cancers, which uses use higher radiation doses than traditional therapies with a better chance of locoregional control while sparing more of the surrounding healthy oral tissue from harmful doses and effects of radiation (Brennan 2017; Studer 2007).

The locoregional control of the primary tumour is the main criterion of successful treatment. Tumours are excised with a margin of clinically normal tissue (typically between $1 \mathrm{~cm}$ and 2 $\mathrm{cm}$ in the UK). Despite this apparent complete clinical surgical excision, the tumour may still be demonstrated at the margins histopathologically; this has prognostic implications (Batsakis 1999; Sutton 2003). Margins apparently histologically free of tumour may demonstrate molecular changes and the presence of such tumour clonogen populations at the margins may be predictive for disease progression (Partridge 2000).

Spread of the tumour to the regional lymph nodes within the neck (cervical nodes) is an early and consistent event in the natural history of oral and oropharyngeal cancers (Haddadin 2000). The extent of cervical involvement is reflected in the staging of the tumour and has prognostic implications (Shah 1990). Therefore, surgical dissection of the cervical lymph nodes at risk of metastasis may be undertaken as part of the management of the primary tumour. The classic radical neck dissections (RND) removed all of the cervical lymph nodes from levels I to $\mathrm{V}$ combined with the sternocleidomastoid muscle, internal jugular vein, submandibular 
gland and the spinal accessory nerve, with resultant significant postoperative morbidity particularly in relation to loss of the accessory nerve. In one study of 100 cases following RND, almost half of the participants experienced shoulder pain, shoulder droop and a reduction in the range of motion (Ewing 1952). One more recent study comparing RND with accessory nerve-sparing surgery found all of the cases with RND had severe shoulder dysfunction compared with only $7 \%$ of the cases who had nerve-sparing surgery (Umeda 2010). RND is now only reserved for advanced neck disease. Modifications of the neck dissection to preserve some or all of the associated structures have reduced morbidity and may now be undertaken as selective neck dissections (Carew 2003; Robbins 2002). There has been an increasing trend of using selective neck dissection as a therapeutic procedure in the clinically NO neck (indicating no palpable nodes on clinical examination). In addition to the extent of neck disease at presentation, spread of the tumour outside the capsule of the lymph nodes (extracapsular spread) is also an indicator of a poor prognosis (Woolgar 2003). Distant metastasis is uncommon in HNC with one study reporting $13.8 \%$ in 1022 cases (Duprez 2017). Locoregional disease recurrence remains the dominant mode of treatment failure for people with advanced tumours (Brizel 1998). Historically, clinicians treating oral cancer did not focus on distant metastatic disease because locoregional control had been the main cause of death and there were fewer effective chemotherapeutic agents to deal with distant metastases. With improvements in locoregional control, distant metastases are an increasing issue in the management of oral cancer.

When early stage tumours ( $T 1$, less than $2 \mathrm{~cm}$, or $T 2,2 \mathrm{~cm}$ to $4 \mathrm{~cm}$ ) present with apparently clinically negative neck nodes, there is controversy over the management of the cervical lymph nodes (Woolgar 2003). To date, imaging of the head and neck region is not sensitive enough to identify nodal micrometastases as the rate of occult metastases has been reported as $23 \%$ to $43 \%$ (Ebrahimi 2012). Studies have demonstrated an improved outcome when a neck dissection has been undertaken at the same time as the resection of the primary tumour rather than waiting for neck disease to present subsequently (Haddadin 2000; Hughes 1993), although others adopt a 'wait and ' policy. One current clinical guideline recommends that T1 and T2 oral cancer with a clinically negative neck should receive prophylactic neck treatment (Paleri 2016). However, this implies overtreatment and treatmentassociated morbidity in the majority of people (Dias 2001). There is evidence of improved overall and disease-free survival in people with early-stage oral squamous-cell cancer (SCC) who had an elective neck dissection in comparison with therapeutic neck dissection (D'Cruz 2015).

The use of sentinel node biopsy (SNB) is now being advocated for small tumours with a clinically negative neck. One UK guideline recommends that biopsy should be offered to people with oral cancer (T1-T2N0), as it is in the Netherlands and Denmark (Holden 2018; NICE 2018). One European study reported a sensitivity of $86 \%$ and negative predictive value of $95 \%$ with SNB and concluded that this is a reliable and safe oncological technique for staging the clinically NO neck in people with T1 and T2 oral cancer (Schilling 2015). Yang 2017 also indicated that a high sensitivity and negative predictive value have been reported with SNB in a larger study including meta-analysis of CT1/T2N0 people with tongue SCC. The widespread introduction of SNB for oral SCC will result in individual treatment that enables people at high risk to be suitably treated early in the disease process, and people at low risk to be spared unnecessary surgery (Schilling 2017).

\section{Why it is important to do this review}

Cochrane Oral Health undertook an extensive prioritisation exercise in 2014 to identify a core portfolio of titles that were the most clinically important ones to maintain on the Cochrane Library (Worthington 2015). The Oral and Maxillofacial Surgery Expert Panel identified this review as a priority (Cochrane Oral Health Priority Reviews).

The management of advanced oral cavity and oropharyngeal cancers is problematic and has traditionally relied on surgery and radiotherapy, both of which are associated with substantial adverse effects. Although there have been new treatments developed, there has been limited improvement in survival since the late 1970s (Warnakulasuriya 2009). Oropharyngeal cancers have relatively 'silent' symptoms, which may not be present during the early stages of the disease. This is a possible explanation for the fact that the disease stage at diagnosis has not altered since the 1960s despite public education (McGurk 2005). Tumour recurrence and the development of multiple primary tumours are the major causes of treatment failure (Day 1992; Partridge 2000; Woolgar 2003). Surgical treatment may be disfiguring and result in a substantially reduced quality of life as people with oral and oropharyngeal cancers are socially isolated, due to difficulties with altered appearance, speech, eating and drinking. Developments in the way in which surgery is delivered aim to improve its efficacy and reduce the impact on people's quality of life.

This review was undertaken as part of a series of reviews looking at the different treatment modalities for oral cancer (Furness 2011; Glenny 2010): surgery, chemotherapy, radiotherapy and immunotherapy. In this update of our surgical review, we aimed to answer two broad questions.

- Does surgery, in addition to chemotherapy, radiotherapy or chemoradiotherapy, improve outcomes for people with oral cavity and oropharyngeal cancers?

- Which type of surgery improves outcomes for people with oral cavity and oropharyngeal cancers?

In this surgical review, we included all randomised controlled trials (RCTs) where more than $50 \%$ of participants had primary tumours in the oral cavity or oropharynx or where separate data could be extracted for these types of cancer. We included only trials where participants in each treatment arm received different surgical interventions (either different techniques or timing); or radiotherapy, chemotherapy or chemoradiotherapy with or without surgery; or surgery versus no surgery.

\section{O B JECT IVES}

\section{Primary objective}

To determine which surgical treatment modalities for oral and oropharyngeal cancers result in increased overall survival, diseasefree survival, locoregional control and reduced recurrence.

\section{Secondary objective}

To determine the implication of treatment modalities in terms of morbidity (quality of life, complications, harms and adverse events) 
and Utilization of the Health care services (costs, hospital days of treatment).

\section{METHODS}

\section{Criteria for considering studies for this review}

\section{Types of studies}

RCTs comparing different surgical treatment modalities or trials of other treatment interventions with and without surgery including radiotherapy and chemotherapy. We anticipated that there would be no studies comparing surgery with placebo (although if there were such studies they would have been included).

\section{Types of participants}

People with oral cancer as defined by the International Classification of Diseases for Oncology (ICD-O) codes as C01-C02, C03, C04, C05-C06 (oral cavity) and cancer of the oropharynx (ICDO: C09, C10). We excluded hypopharynx (ICD-0: C13), nasopharynx (ICD-O: C11), larynx (ICD-O: C32) and cancers of the lip (ICD-O: C00) (WHO 1990).

We included studies of HNC with cases of oral cancer (as long as at least $50 \%$ of participants had oral cavity or oropharyngeal cancer, or data for these cancers alone are available separately).

Cancers were primary SCCs arising from the oral mucosa. We included histological variants of SCCs (e.g. adenosquamous, verrucous, basaloid, papillary). Although they are known to have differing natural history to most conventional SCCs, they have a common aetiology, incidence is low and they are generally managed in the same way. We included carcinoma in situ.

We excluded epithelial malignancies of the salivary glands, odontogenic tumours, all sarcomas and lymphomas as these have a different aetiology and are managed differently.

\section{Types of interventions}

Surgical treatment of the primary tumour is typically one of the primary treatment interventions. Surgical treatment could have included traditional scalpel-based surgery, laser cutting or ablation, or harmonic scalpel. We included trials that compared surgical treatment with another surgical intervention; different treatment modalities such as radiotherapy, chemotherapy, immunotherapy/biotherapy with or without surgery; any combinations were considered providing they were compared to surgery in at least one arm of the study. We did not consider salvage or palliative surgery.

We included studies that carried out surgical treatment of the neck lymph nodes (cervical lymph nodes) before, after or at the same time as surgical treatment of the primary tumour. We did not consider studies when there was surgical treatment of the cervical lymph nodes but no treatment of the primary tumour. We included studies concerned with cervical lymph node management in the surgical treatment of the primary tumour.

The treatments received and compared must have been the primary treatment for the tumour and participants should not have received any prior intervention other than diagnostic biopsy.

\section{Types of outcome measures}

As we did not expect many data, we planned to report outcomes at all time points reported, other than for 'time to event' data as the hazard ratios (HR) would be used to summarise this.

\section{Primary outcomes}

- Overall survival (or total mortality) (disease-related mortality will also be studied, if possible).

- Disease-free survival (or new disease, progression and mortality).

- Locoregional recurrence.

- Recurrence.

\section{Secondary outcomes}

- Harms associated with treatment.

- Quality of life.

- Direct and indirect costs to patients and health services.

- Participant satisfaction.

\section{Search methods for identification of studies}

For previous versions of this review, searches were conducted as part of a series of Cochrane Reviews on the treatment modalities for treating oral cavity and oropharyngeal cancer. The reviews were divided into four themes: surgery, chemotherapy, radiotherapy and immunotherapy/targeted therapies. A search strategy was developed that would encompass three of the four broad themes simultaneously (surgery, chemotherapy, radiotherapy, see Bessell 2011 for details of the search strategy). From 2011 onwards, we conducted a more specific search for the surgery theme.

\section{Electronic searches}

Cochrane Oral Health's Information Specialist conducted systematic searches in the following databases for RCTs and controlled clinical trials. There were no language, publication year or publication status restrictions.

- Cochrane Oral Health's Trials Register (searched 20 December 2017; Appendix 1);

- Cochrane Central Register of Controlled Trials (CENTRAL; 2017, Issue 11) in the Cochrane Library (searched 20 December 2017; Appendix 2);

- MEDLINE Ovid (1946 to 20 December 2017; Appendix 3);

- Embase Ovid (1980 to 20 December 2017; Appendix 4).

Subject strategies were modelled on the search strategy designed for MEDLINE Ovid. Where appropriate, they were combined with subject strategy adaptations of the highly sensitive search strategy designed by Cochrane for identifying RCTs and controlled clinical trials as described in the Cochrane Handbook for Systematic Reviews of Interventions Chapter 6 (Lefebvre 2011).

\section{Searching other resources}

We searched the following trial registries for ongoing studies:

- US National Institutes of Health Ongoing Trials Register ClinicalTrials.gov (clinicaltrials.gov; searched 20 December 2017; Appendix 5); 
- World Health Organization International Clinical Trials Registry Platform (apps.who.int/trialsearch; searched 20 December 2017; Appendix 6).

When necessary, we contacted authors of key papers and abstracts to request further information about their trials.

We searched the reference lists of included studies and relevant systematic reviews for further studies.

We did not perform a separate search for adverse effects of interventions used; we considered adverse effects described in included studies only.

\section{Data collection and analysis}

\section{Selection of studies}

At least two review authors (from HW, VB, AMG, DC, MM) independently scanned the titles and abstracts (when available) of all reports identified through the electronic searches. The search was designed to be sensitive and include controlled clinical trials; these were filtered out early in the selection process if they were not randomised. As studies involving oral cancer are often included with those of the head and neck, we undertook a broad search to include all possible studies (Figure 1). For studies appearing to meet the inclusion criteria, or for which there were insufficient data in the title and abstract to make a clear decision, we obtained the full report. We excluded data from conference abstracts alone from the review. Two review authors independently assessed full reports obtained from the searches to establish whether the studies met the inclusion criteria or not. We resolved disagreements by discussion or by consulting a third review author if necessary. We recorded studies rejected at this or subsequent stages in the Characteristics of excluded studies table, and recorded our reasons for exclusion. 
Figure 1. Study flow diagram.

7 studies included in previous version of review

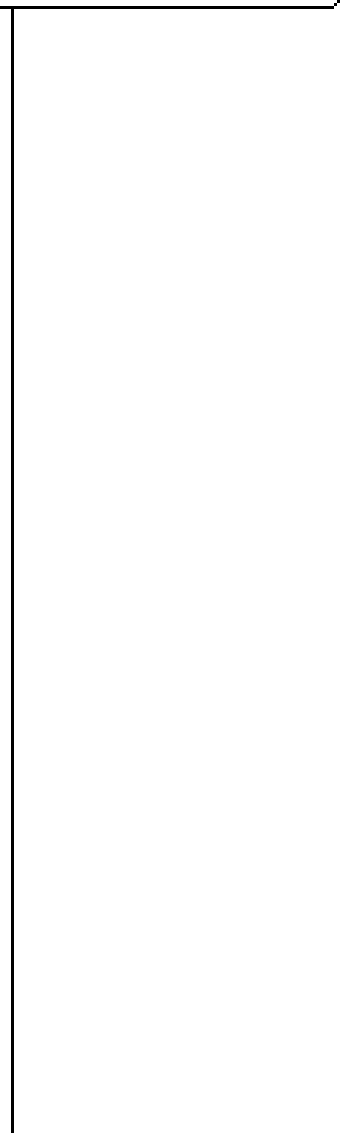

\section{5 records identified through database searching}

0 additional records identified through other sources

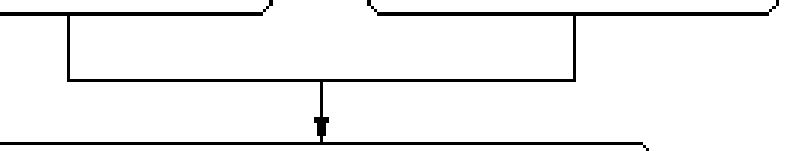

6929 records after duplicates removed
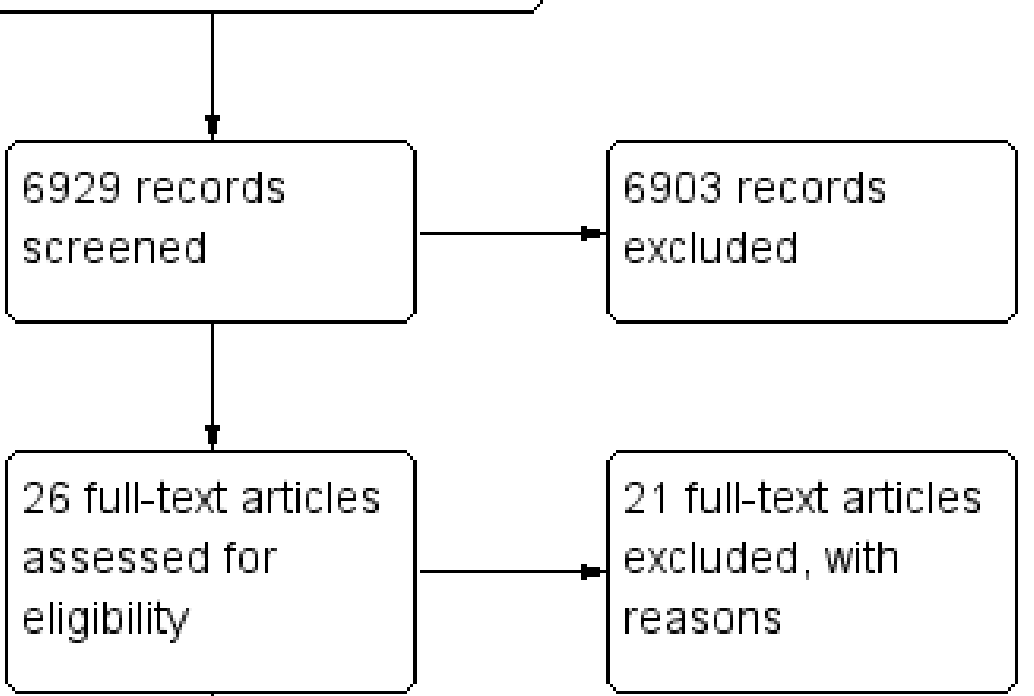

\section{2 studies included in qualitative synthesis}

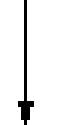

\section{9 studies included} in quantitative synthesis (meta-analysis) 


\section{Data extraction and management}

At least two review authors independently extracted data from included studies. The data extraction forms were piloted on several papers and modified as required before use. We discussed any disagreements and a third review author was consulted where necessary. However, group discussion was often required following data extraction due to the complexity of the data presented. When necessary, we contacted study authors for clarification or missing information.

For each trial, we recorded the following data.

- Year of publication, country of origin and source of study funding.

- Details of the participants including demographic characteristics and criteria for inclusion and exclusion, proportion with oral cavity and oropharyngeal cancer.

- Details of the type of intervention, timing and duration.

- Details of the outcomes reported, including method of assessment, and time intervals.

We planned to include HNC trials with only combined data (i.e. no outcome data available by primary tumour site) where greater than $50 \%$ of participants presented with oral/oropharyngeal cancer; however, where separate 'pure' oral/oropharyngeal cancer data were available for a trial, we extracted and analysed these 'pure' data and analysed and ignored the combined head and neck data.

\section{Assessment of risk of bias in included studies}

At least two review authors independently conducted assessment of risk of bias in included studies using the Cochrane 'Risk of bias' tool (Higgins 2011). We assessed six domains for each included study: sequence generation, allocation concealment, blinding (of participant, carer, outcome assessor), completeness of outcome data, selective outcome reporting and other potential sources of bias. We made an overall risk of bias assessment for each study.

For this systematic review, we assessed risk of bias according to the following.

- Sequence generation: low risk if use of a random number table, computerised system, central randomisation by statistical coordinating centre, randomisation by an independent service using minimisation technique, permuted block allocation or Zelan technique. If the paper merely stated randomised or randomly allocated with no further information, we assessed this as being unclear.

- Allocation concealment: low risk if centralised allocation including access by telephone call or fax, or pharmacycontrolled randomisation, sequentially numbered, sealed, opaque envelopes.

- Blinding: as mortality is the primary outcome that is most frequently and reliably reported, we decided to assess all trials as being at low risk of bias for this domain.

- Outcome data: outcome data were considered complete if all participants randomised were included in the analysis of the outcome(s). However, in trials of treatment for cancer this is rarely the case. Trials where less than $10 \%$ of those randomised were excluded from the analysis, and where reasons for exclusions were described for each group, and where both numbers and reasons were similar in each group, were assessed at low risk of bias due to incomplete outcome assessment. Where postrandomisation exclusions were greater than $10 \%$, or reasons were not given for exclusions from each group, or where rates and reasons were different for each group, we assessed the risk of bias due to (in)complete outcome data as unclear.

- Selective outcome reporting: we assessed a trial at low risk of bias due to selective outcome reporting if the outcomes of interest that were described in the methods section were systematically reported in the results section. Where reported outcomes did not include those outcomes specified or expected in trials of treatments for oral cancer, or where additional analyses were reported, we assessed this domain as unclear.

- Other bias: we noted examples of potential sources of bias such as imbalance in potentially important prognostic factors between the treatment groups at baseline, or the use of a cointervention in only one group (e.g. nasogastric feeding). If information was not available about the intervention groups at baseline, we assessed studies as being at unclear risk of bias.

\section{Measures of treatment effect}

The primary outcome most frequently and reliably reported was total mortality, expressed as an HR. An HR provides an estimate of the ratio of the hazard rates, for a particular event, between the experimental group and a control group over the duration of the entire study. For overall survival, the event of interest is death (total mortality). It is acknowledged that it is preferable to talk in terms of overall survival; however, statistically, the estimate of effect is the HR of death.

We entered these data into the meta-analysis using the inverse variance method. If studies did not quote HRs, we calculated the $\log \mathrm{HR}$ and the standard error from the available summary statistics or Kaplan-Meier curves, according to the methods proposed by Parmar and colleagues (Parmar 1998), or requested these data from authors.

For dichotomous outcomes, we expressed the estimates of effect of an intervention as risk ratios (RR) together with $95 \%$ confidence intervals $(\mathrm{Cl})$. Dichotomous data were only used for primary outcomes where HRs were unavailable or could not be calculated. We planned to combine data of similar follow-up periods.

\section{Assessment of heterogeneity}

We conducted meta-analyses only if there were studies of similar comparisons reporting the same outcome measures. We assessed the significance of any discrepancies in the estimates of the treatment effects from the different trials using Cochrane's test for heterogeneity and the $\mathrm{I}^{2}$ statistic, and we investigated any heterogeneity.

\section{Data synthesis}

We conducted meta-analyses only if there were studies of similar comparisons reporting the same outcome measures. We combined RR for dichotomous data, and HRs for survival data, using randomeffect models.

\section{Subgroup analysis and investigation of heterogeneity}

Due to the different natural history and treatment regimens for oral cavity and oropharyngeal cancers, we planned to analyse these cancer types separately, if possible. 


\section{Sensitivity analysis}

We planned sensitivity analysis (to examine the effects of randomisation, allocation concealment, blinded outcome assessment (if appropriate) and quality of follow-up/completeness of data set), but there were insufficient data.

\section{RES U L T S}

\section{Description of studies}

\section{Results of the search}

We identified 6929 research papers through the electronic searching for this update, after the removal of duplicates (Figure 1). Screening of the titles and abstracts resulted in the identification of 26 potentially relevant trials for inclusion in the review. We retrieved full-text copies of these articles. Further assessment of the papers resulted in five trials being included in this update of the review. Four of these trials were newly identified (Guo 2014; lyer 2015; Mehanna 2017; Rastogi 2018), and one trial had previously been identified (D'Cruz 2015).

\section{Included studies}

Of the 12 trials included in the review, five were multicentred, with the number of centres ranging from two to 37 . Three trials were undertaken in India (D'Cruz 2015; Fakih 1989; Rastogi 2018), two in Brazil (BHNCSG 1998; Kligerman 1994), two in China (Guo 2014; Yuen 2009), two in the UK (Mehanna 2017; Robertson 1998), one in centres across Europe (Austria, Germany and Switzerland) (Bier 1994), one in France (Vandenbrouck 1980), and one in Singapore (lyer 2015). Twenty-four trials, previously included in this review, have now been excluded, because they better fit in the other oral cancer treatment reviews (see Characteristics of excluded studies for details). Three trials required personal communication with the authors of the papers for retrieval of extra information (Kligerman 1994; Mehanna 2017; Robertson 1998).

\section{Participants}

Participants were recruited over periods ranging from two years to 11 years, with the earliest recruitment commencing in 1966 (Vandenbrouck 1980). A total of 2300 participants were randomly allocated to treatments and 2090 were included in the outcome evaluations. Most of the participants (2148) had oral cavity tumours and the remainder had oropharyngeal tumours.

All included trials reported tumour extent (TNM), four of which included participants with T1 to T2 tumours (D'Cruz 2015; Fakih 1989; Kligerman 1994; Yuen 2009), two with T2 to T4 tumours (BHNCSG 1998; Robertson 1998), two with T1 to T3 tumours (Rastogi 2018; Vandenbrouck 1980), and three with T1 to T4 tumours (Guo 2014; Iyer 2015; Mehanna 2017). In seven of the trials, participants had clinically negative neck nodes (BHNCSG 1998; D'Cruz 2015; Fakih 1989; Kligerman 1994; Rastogi 2018; Vandenbrouck 1980; Yuen 2009), three trials included participants with neck nodes clinically staged as N0-2 (Guo 2014; lyer 2015; Robertson 1998), and one trial included participants with clinically staged N2-3 nodes (Mehanna 2017). The trial by Bier 1994 did not record the tumour stage or node status of the participants at trial entry (Table 1 ).

Of the 12 included trials, eight included recruited participants with oral cavity cancer only (BHNCSG 1998; Bier 1994; D'Cruz 2015; Fakih
1989; Kligerman 1994; Rastogi 2018; Vandenbrouck 1980; Yuen 2009); two included participants with oral cavity or oropharyngeal cancer (Guo 2014; Robertson 1998); one included participants with cancer of the oral cavity, oropharynx, hypopharynx, larynx and maxillary sinus (lyer 2015); and one included participants with cancer of the oral cavity, tonsil, base of tongue, supraglottis and glottis or subglottis (Mehanna 2017).

\section{Interventions}

None of the included trials compared different surgical approaches to the excision of the primary tumour.

Nine trials of participants with oral cavity cancers compared either different surgical techniques for management of the lymph nodes in the neck or different timing for removal of the lymph nodes in the neck (BHNCSG 1998; Bier 1994; D'Cruz 2015; Fakih 1989; Guo 2014; Kligerman 1994; Rastogi 2018; Vandenbrouck 1980; Yuen 2009). Five trials compared the timing of neck dissection; either elective neck dissection at the same time as excision of the primary tumour or therapeutic neck dissection (delayed until nodes became clinically positive) (D'Cruz 2015; Fakih 1989; Kligerman 1994; Vandenbrouck 1980; Yuen 2009). Kligerman 1994 used a supraomohyoid (SOH) approach for the elective neck dissection in a group of participants with clinically negative neck nodes compared with a therapeutic neck dissection if the nodes became clinically positive. Yuen 2009 compared an elective selective neck dissection at the time of glossectomy with glossectomy alone plus therapeutic neck dissection if nodes became clinically positive. Fakih 1989 used elective RND at the same time as resection of the primary tumour in a group with clinically negative neck nodes. Vandenbrouck 1980 compared elective RND within two months of resection of the primary tumour with therapeutic neck dissection. D'Cruz 2015 compared a selective neck dissection with a modified therapeutic neck dissection.

Four trials compared different types of neck dissection surgery at the time of removal of the primary tumour (BHNCSG 1998; Bier 1994; Guo 2014; Rastogi 2018). In the trial by Bier 1994, both groups had a radical resection of the primary tumour. One group had RND at the same time as resection and the other had selective neck dissection surgery. The Brazilian Study group compared a modified RND with a $\mathrm{SOH}$ neck dissection in conjunction with resection of the primary tumour (BHNCSG 1998). Rastogi 2018 compared superselective neck dissection with $\mathrm{SOH}$ neck dissection in conjunction with resection of the primary tumour. Guo 2014 compared $\mathrm{SOH}$ neck dissection with modified RND in conjunction with resection of the primary tumour.

The trial by Robertson 1998 compared surgery followed by radiotherapy with radiotherapy alone in a group of participants with either oral cavity or oropharyngeal cancer. lyer 2015 compared surgery and adjuvant radiotherapy with concurrent chemoradiotherapy. Mehanna 2017 compared positron-emission tomography-computed tomography (PET-CT) guided watch and wait policy (with neck dissection undertaken only if no/incomplete response to chemoradiotherapy identified) with planned neck dissection before or after radical chemoradiotherapy for locally advanced head and neck SCC.

\section{Outcome measures}

The duration of follow-up in the included trials ranged from approximately 15 months (Bier 1994) to 122 months (Yuen 2009). All 
trials except one reported either total mortality or overall survival (Yuen 2009), but not all provided data in a form suitable for inclusion in meta-analysis. Six trials reported disease-free survival (Bier 1994; D'Cruz 2015; Fakih 1989; Kligerman 1994; Vandenbrouck 1980; Yuen 2009), and seven trials reported recurrence (BHNCSG 1998; D'Cruz 2015; Fakih 1989; Kligerman 1994; Rastogi 2018; Robertson 1998; Yuen 2009).

Five trials mentioned harms/adverse events (BHNCSG 1998; D'Cruz 2015; Guo 2014; Mehanna 2017; Robertson 1998). BHNCSG 1998 reported the total number of adverse events in each group but not the number of participants affected. Two trials reported the percentages of participants in each group who experienced adverse effects (D'Cruz 2015; Robertson 1998). One trial reported quality-adjusted-life-years (QALYs), costs and harms/ adverse events (Mehanna 2017). One trial reported hospital days of treatment (Guo 2014).

\section{Excluded studies}

We excluded 24 trials that were previously included in this review because they better fit in the other oral cancer treatment reviews. Four previously included trials (Ang 2001; Lawrence 1974; Sanguineti 2005; Terz 1981) are now included in the radiotherapy review (Glenny 2010); 17 previously included trials (Bernier 2004; Cooper 2004; Lam 2001; Laramore 1992; Licitra 2001; Luboinski 1985; Maipang 1995; Mohr 1994; Paccagnella 1994; Rao 1991; Rentschler 1987; Richard 1991; Schuller 1988; Szabo 1999; Szpirglas 1978; Volling 1999; Weissler 1992) are now included in the chemotherapy review (Furness 2011), and three previously included trials are being considered for inclusion in the immunotherapy review, which is currently being prepared. One trial was excluded from this review because less than $50 \%$ of the participants had oral cavity or oropharyngeal cancer and their data could not be extracted separately (Hintz 1979a).

\section{Risk of bias in included studies}

\section{Allocation}

Four of the included trials reported adequate sequence generation methods (D'Cruz 2015; Fakih 1989; Mehanna 2017; Robertson 1998); in the remaining eight trials, the methods of sequence generation were unclear. Two trials reported adequate allocation concealment (Robertson 1998; Vandenbrouck 1980), but only one trial was assessed as being at low risk of bias in both of these domains (Robertson 1998).

\section{Blinding}

Blinding of participants and clinicians is not feasible in surgical trials, but blinding of outcome assessment is both possible and desirable. However, as mortality is the primary outcome that is most frequently and reliably reported, a decision was made to assess all trials as being at low risk of bias for this domain.

\section{Incomplete outcome data}

We assessed nine of the included trials at low risk of bias with regard to incomplete outcome data because all the randomised participants were adequately accounted for in the outcome evaluation (BHNCSG 1998; Guo 2014; lyer 2015; Kligerman 1994; Mehanna 2017; Rastogi 2018; Robertson 1998; Vandenbrouck 1980; Yuen 2009). Of the remaining trials, we assessed two at high risk with regard to this domain (Bier 1994; Fakih 1989), and one at unclear (D'Cruz 2015). Both Bier 1994 and Fakih 1989 presented an interim analysis of a subgroup of participants and the final analysis has not been published as far as we are aware. In both of these trials, it was unclear how many participants were randomly allocated to each intervention group, and how many in each group were subsequently excluded from the analysis or analysed in a different group from that to which they were originally allocated (or both). It is likely that those excluded from the analysis (because they refused surgery or had extracapsular rupture during surgery) had a different outcome from those included in the analysis.

\section{Selective reporting}

We assessed 11 of the included trials as free of selective reporting bias as they reported on expected, clinically important outcomes. Yuen 2009 did not report total mortality or overall survival, so was at high risk of bias for this domain.

\section{Other potential sources of bias}

We assessed eight trials at low risk of other bias because the intervention groups appeared to be similar at baseline and there were no other sources of bias (BHNCSG 1998; D'Cruz 2015; Guo 2014; lyer 2015; Mehanna 2017; Rastogi 2018; Vandenbrouck 1980; Yuen 2009).

Three trials provided no information regarding the baseline characteristics of participants in each group, and so these trials were at unclear risk of other bias (Bier 1994; Fakih 1989; Kligerman 1994).

We assessed Robertson 1998 at high risk of other bias because, although planned recruitment was 350 participants, this trial was stopped after only 35 participants were recruited because clinicians felt it was unethical to continue. While appropriate procedures were followed and an interim analysis was conducted and reported, it is not clear from this report whether a priori stopping rules were in place. Additionally, more than half of the participants in this trial did not receive radiotherapy as planned due to problems with faulty equipment. It is likely that this would have had a greater effect on the outcomes the of radiotherapy-only arm of the trial.

\section{Overall risk of bias}

A summary of the 'Risk of bias' assessment is presented in Figure 2. Overall, we assessed four studies at high risk of bias (Bier 1994; Fakih 1989; Robertson 1998; Yuen 2009), and eight trials at unclear risk of bias (BHNCSG 1998; D'Cruz 2015; Guo 2014; lyer 2015; Kligerman 1994; Mehanna 2017; Rastogi 2018; Vandenbrouck 1980), for all of the outcomes evaluated. 
Figure 2. Risk of bias summary: review authors' judgements about each risk of bias item for each included study.

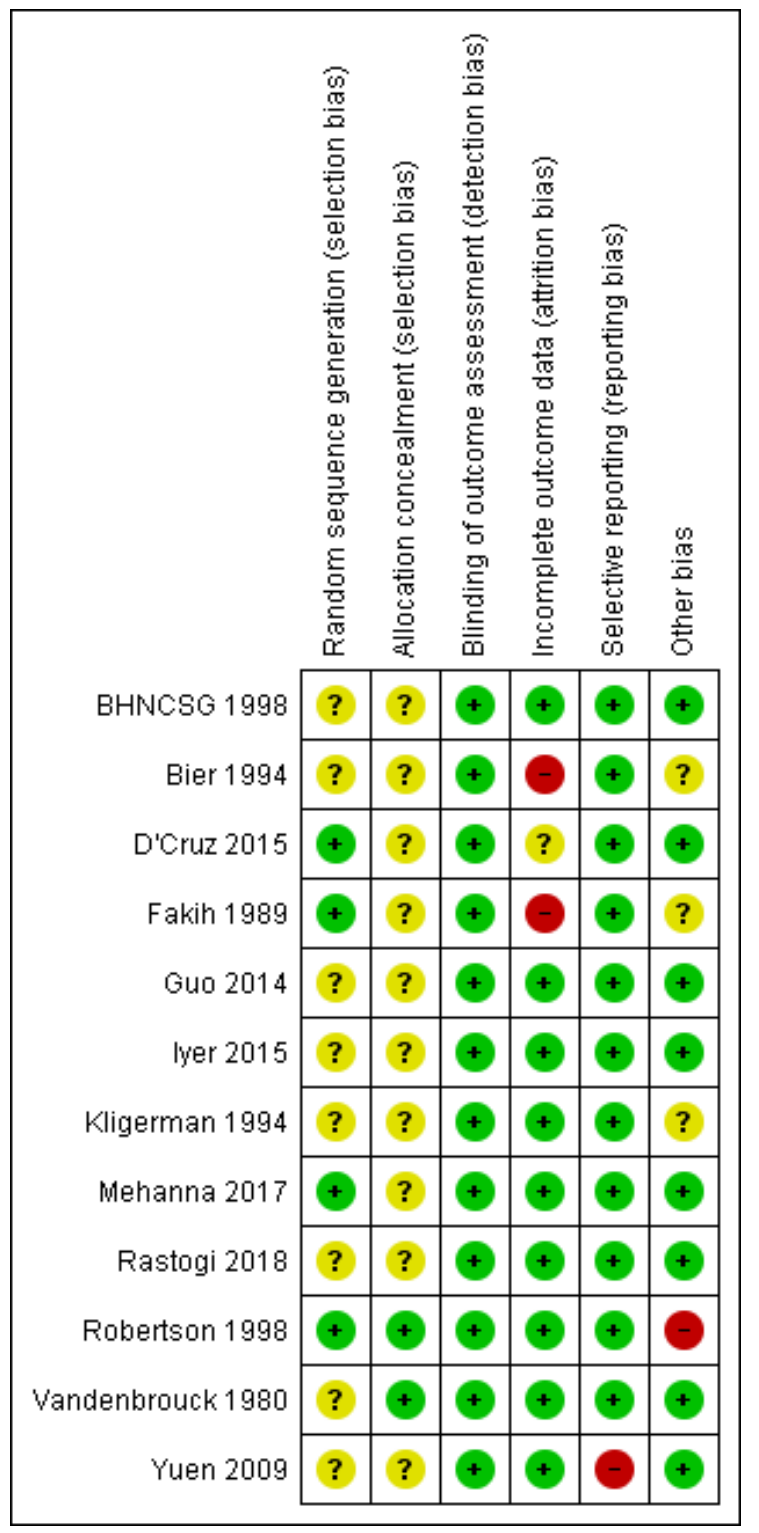

\section{Effects of interventions}

See: Summary of findings for the main comparison Elective neck dissection versus therapeutic (delayed) neck dissection; Summary of findings 2 Elective radical neck dissection versus elective selective neck dissection; Summary of findings 3 Surgery plus radiotherapy versus radiotherapy alone; Summary of findings 4 PET-CT following chemoradiotherapy versus planned neck dissection either before or after chemoradiotherapy; Summary of findings $\mathbf{5}$ Surgery plus adjuvant radiotherapy versus chemotherapy; Summary of findings 6 Supraomohyoid neck dissection versus modified radical neck dissection; Summary of findings 7 Super-selective neck dissection versus selective neck dissection

\section{Comparison 1: elective neck dissection versus therapeutic (delayed) neck dissection}

See Summary of findings for the main comparison.
Five trials compared the timing of the neck dissection; either at the same time as resection of the primary tumour or as a separate procedure subsequent to resection of the primary, with dissection of the neck nodes being undertaken only after there was clinical evidence of disease in the neck nodes (D'Cruz 2015; Fakih 1989; Kligerman 1994; Vandenbrouck 1980; Yuen 2009). All participants had oral cavity cancers, specifically tongue or floor of mouth tumours and clinically negative neck nodes on study entry.

Fakih 1989 and Vandenbrouck 1980 performed classical RND procedures and pooled data after one year (Fakih 1989) and three years (Vandenbrouck 1980) of follow-up. D'Cruz 2015 and Yuen 2009 performed selective neck dissection of level I to III nodes with D'Cruz 2015 reporting data at three years. Kligerman 1994 used a SOH elective neck dissection procedure, and reported data after 3.5 years of follow-up. Fakih 1989 and Yuen 2009 was at overall high risk of bias and Kligerman 1994, Vandenbrouck 1980, and D'Cruz 2015 were at unclear overall risk of bias. 


\section{Overall survival (or total mortality)}

Two trials presented overall survival data as HRs (D'Cruz 2015; Vandenbrouck 1980) and two trials as RRs (Fakih 1989 at one year; Vandenbrouck 1980 at three years). The meta-analysis for the HRs showed no evidence of a difference between the interventions (Analysis 1.1; very low-certainty evidence)). We were unable to pool the binary data due to different follow-up periods. Fakih 1989 found no evidence of a difference between elective RND and therapeutic neck dissection at one-year follow-up (very lowcertainty evidence); however, Kligerman 1994, where elective surgery was the less extensive $\mathrm{SOH}$, found a difference in overall survival after 3.5 years of follow-up, favouring elective $\mathrm{SOH}$ neck dissection compared to therapeutic neck dissection (Analysis 1.2; very low-certainty evidence).

\section{Disease-free survival (or new disease, progression and mortality)}

Three trials reported the data for disease-free survival as HRs (D'Cruz 2015; Kligerman 1994; Vandenbrouck 1980), and two trials as RRs (Fakih 1989 at one year; Vandenbrouck 1980 at three years). The pooled HR showed no evidence of a difference between elective neck dissection and therapeutic neck dissection (HR $0.73,95 \% \mathrm{Cl}$ 0.25 to 2.11; Analysis 1.3; very low-certainty evidence). One study provided very low-certainty evidence of a benefit from elective $\mathrm{SOH}$ neck dissection when compared to therapeutic neck dissection (HR $0.32,95 \% \mathrm{Cl} 0.12$ to 0.84 ; Analysis 1.3) (Kligerman 1994). The binary data showed no evidence of a difference between the interventions (Analysis 1.4; very low-certainty evidence).

\section{Locoregional recurrence}

Four trials reported binary data on locoregional recurrence ( $D$ 'Cruz 2015; Fakih 1989; Kligerman 1994; Vandenbrouck 1980), but the data were not suitable for meta-analysis due to the differences between studies in the type of surgery and the duration of follow-up (Analysis 1.5; very low-certainty evidence). The results were mixed, with three trials suggesting neither intervention was superior while the study evaluating elective $\mathrm{SOH}$ neck dissection concluding this approach may reduce locoregional recurrence more than therapeutic delayed ND.

\section{Recurrence}

Two trials reported recurrence rates at different sites, but numbers were too small to determine whether there may have been a difference between the groups in rate of recurrence of either a second primary tumour or distant metastases (data not shown) (Vandenbrouck 1980; Yuen 2009).

\section{Secondary outcomes}

In D'Cruz 2015, $6.6 \%$ of the elective-surgery participants showed adverse events, while $3.6 \%$ of participants in the therapeuticsurgery group reported adverse events. These included neck haematoma, chyle leak, oral bleeding, postoperative infection and anaphylaxis. None of the other trials reported on adverse events.

None of the trials reported on quality of life, costs or any measure of participant satisfaction.

\section{Comparison 2: elective radical neck dissection versus elective selective neck dissection}

See Summary of findings 2.
Two trials compared neck dissection surgery of differing extent (BHNCSG 1998; Bier 1994). There were differences between the two studies with regard to participant characteristics at baseline and surgical procedures so meta-analysis was not undertaken.

BHNCSG 1998 compared a modified classical neck dissection procedure with accessory nerve preservation, to a $\mathrm{SOH}$ neck dissection to achieve a compartmental excision of levels I to III neck nodes in 148 participants with T2 to T4 primary lesions in the oral cavity and clinically negative nodes. Frozen sections were carried out on the nodes during surgery and three participants in the $\mathrm{SOH}$ group who had histologically positive nodes then underwent the modified classical neck dissection instead. This trial was at overall unclear risk of bias.

In Bier 1994, 104 participants with either clinically negative or positive but movable neck nodes were randomised to either RND or a selective neck dissection where the platysma, sternocleidomastoid muscle, internal jugular vein and accessory nerve were left in place. Primary tumours were in the oral cavity and the study was at overall high risk of bias.

\section{Overall survival (or total mortality)}

There was no evidence of a difference in overall survival (Analysis 2.1 ; very low-certainty evidence).

\section{Disease-free survival (or new disease, progression and mortality)}

Only Bier 1994 reported disease-free survival and there was no evidence of a difference (Analysis 2.2; very low-certainty evidence).

\section{Locoregional recurrence}

Neither trial reported locoregional recurrence.

\section{Recurrence}

Only BHNCSG 1998 reported recurrence as binary data at five years, and there was no evidence of a difference in disease recurrence (Analysis 2.3; very low-certainty evidence).

\section{Secondary outcomes}

BHNCSG 1998 reported the following adverse effects: flap necrosis, wound infection, fistula, vascular rupture, haematoma, seroma and chyle fistula. There were no complications in $45 / 76$ participants in the modified RND group and none in 54/72 participants in the $\mathrm{SOH}$ neck dissection group. There were two postoperative deaths in the modified RND group and one in the $\mathrm{SOH}$ neck dissection group.

Neither trial reported other secondary outcomes.

\section{Comparison 3: surgery plus radiotherapy versus radiotherapy alone}

See Summary of findings 3.

One trial compared surgery plus postoperative radiotherapy with radiotherapy alone (Robertson 1998). Participants in the surgery group had wide local excision of the primary tumour together with either a RND or a more selective neck dissection at the discretion of the surgeon. It was planned to accrue 175 participants, with oral cavity or oropharyngeal cancer (neck nodes clinically staged as NO to 2) to each arm of the trial but after 35 participants had been 
recruited the trial was stopped due to the high death rate in the radiotherapy alone arm.

\section{Overall survival (or total mortality)}

Data in Analysis 3.1 are from an interim analysis of 35 participants after 23 months and showed an HR for total mortality of $0.24(95 \% \mathrm{Cl}$ 0.10 to 0.59 ), favouring the surgery group. This estimate should be interpreted with extreme caution for several reasons. The authors stated that "the difference in survival is likely to be inflated" due to the small number of participants in the analysis, the fact that only $41 \%$ of participants in the radiotherapy only arm received their radiotherapy as planned due to problems with faulty machines, and that there were several other protocol violations in the trial. In the surgery plus radiotherapy arm, $50 \%$ of the participants received radiotherapy as planned, but $12 \%$ of participants received neither surgery to the mandible nor neck dissection.

\section{Disease-free survival (or new disease, progression and mortality)}

The trial did not report this outcome.

\section{Locoregional recurrence}

The trial did not report locoregional recurrence.

\section{Recurrence}

The trial did not report recurrence.

\section{Secondary outcomes}

There were the following severe acute adverse effects in both groups (Robertson 1998): subcutaneous fibrosis, telangiectasia (1 $\mathrm{cm}^{2}$ to $4 \mathrm{~cm}^{2}$ ), and moderate to severe oedema, xerostomia, trismus and dysphagia. Subcutaneous fibrosis was more prevalent in the surgery plus radiotherapy group $(P=0.042)$, but the prevalence of other adverse effects appeared to be similar in each group.

The trial did not report other secondary outcomes.

\section{Comparison 4: PET-CT following chemoradiotherapy versus planned neck dissection either before or after chemoradiotherapy}

See Summary of findings 4.

One trial at overall unclear risk of bias compared PET-CT-guided surveillance (with neck dissection only if no response or incomplete response to chemoradiotherapy) to planned neck dissection (either before or after chemoradiotherapy) in participants with stage N2 or N3 disease (Mehanna 2017). The study recruited 564 participants.

\section{Overall survival (or total mortality)}

There was no evidence of a difference in total mortality between PET-CT 'watch-and-wait' and planned neck dissections (HR 0.92, $95 \% \mathrm{Cl} 0.65$ to 1.31 ; Analysis 4.1; very low-certainty evidence).

\section{Disease-free survival (or new disease, progression and mortality)}

There were limited data that we were unable to use. Mehanna 2017 reported that "Disease-specific mortality and mortality from other causes did not differ significantly between the two groups $(P=0.80$ and 0.41 , respectively, according to Gray's test for differences)."

\section{Locoregional recurrence}

There were limited data that we were unable to use. Mehanna 2017 reported that "The 2-year rate of locoregional control was $91.9 \%(95 \% \mathrm{Cl}, 88.5$ to 95.3$)$ in the surveillance group and $91.4 \%(95 \% \mathrm{Cl}, 87.8$ to $95.0 \%)$ in the planned-surgery group. In the latter group, the 2-year rate of locoregional control was $90.4 \%(95 \% \mathrm{Cl}, 86.0$ to 94.7$)$ among patients who underwent neck dissection after chemoradiotherapy and $94.8 \%(95 \% \mathrm{Cl}, 89.0$ to 100) among patients who underwent neck dissection before chemoradiotherapy."

\section{Recurrence}

There were limited data that we were unable to use. Mehanna 2017 reported that "Documented recurrence in the nodes only (without concurrent disease in the primary site) occurred in 1 patient in the planned-surgery group and in 3 patients in the surveillance group. Distant metastases were identified in 23 patients in the plannedsurgery group and in 21 patients in the surveillance group."

\section{Secondary outcomes}

There were 22 surgical complications after neck dissection in the surveillance group compared with 83 in the planned-surgery group.

Mehanna 2017 assessed quality of life using EORTC QLQ-C30 questionnaire. There was a small difference in global health status scores in favour of the surveillance group at six months after randomisation relative to planned-surgery group (mean change 4.94; $\mathrm{P}=0.09$ ). This difference narrowed at 12 months (mean change 3.03; $P=0.09$ ) and was no longer apparent at 24 months (mean change $-0.81 ; \mathrm{P}=0.85$ ).

There was an economic evaluation undertaken consisting of two components: a within-trial analysis and a decision analytic model. The primary analysis was conducted from a National Health Service (NHS) secondary care perspective (i.e. including NHS hospital costs). PET-CT guided surveillance was more cost effective than planned neck dissection. Compared with planned neck dissection, PET-CT surveillance produced an incremental net health benefit of 0.16 quality-of-life years (QALYs) $(95 \% \mathrm{Cl} 0.03$ to 0.28$)$ over the trial period, and 0.21 QALYs $(95 \% \mathrm{Cl}$ to 0.41 to 0.85$)$ over the modelled lifetime horizon.

The trial reported none of the other secondary outcomes.

\section{Comparison 5: surgery plus adjuvant radiotherapy versus chemotherapy}

See Summary of findings 5.

One trial at overall unclear risk of bias compared neck dissection surgery plus adjuvant radiotherapy versus chemotherapy in 119 participants with histologically confirmed respectable stage III/IV head and neck SCC (excluding nasopharynx and salivary gland SCC) (lyer 2015). The median follow-up for surviving participants was 13 years.

\section{Overall survival (or total mortality)}

The study report stated, "For the oral cavity, survival was significantly better in patients who underwent surgery and RT compared with the CRT group." However, there were no useable data. 
Disease-free survival (or new disease, progression and mortality)

The study reported that disease-free survival was statistically significant in favour of the surgery group $(P=0.038)$, but there were no useable data.

\section{Locoregional recurrence}

The study reported that locoregional recurrence-free survival was not statistically significant between the groups $(P=0.355)$, but there were no useable data.

\section{Recurrence}

The study reported that distant recurrent-free survival was not statistically significant between the groups, but there were no useable data.

The study report stated, "The 5-year DSS rates were $68 \%$ for the S [surgery] arm versus $12 \%$ for the C [chemotherapy] arm (P5.038) (Fig. 3a). Similarly, rates of distant metastasis were higher among patients on the $\mathrm{C}$ arm, with 5-year DRFS [distant recurrent-free survival] rates of $50 \%$ compared with $92 \%$ for patients on the $S$ arm (P5.05) (Fig. 3b). However, no statistically significant difference was observed in locoregional disease recurrence rates between the treatment arms (P5.355) (Fig. 3c), although there may have been a trend favoring the $\mathrm{S}$ arm."

\section{Secondary outcomes}

The trial reported no secondary outcomes.

\section{Comparison 6: supraomohyoid neck dissection versus modified radical neck dissection}

See Summary of findings 6 .

One trial at overall unclear risk of bias compared $\mathrm{SOH}$ neck dissection versus modified RND (Guo 2014). Participants, with oral cavity or oropharyngeal cancer, had T1 to T4 tumours with neck nodes clinically staged as N0 to 2 .

\section{Overall survival (or total mortality)}

The study reported overall survival/total mortality during the follow-up period (with different follow-up times), so could not be used for analysis. The study report stated, "During the follow-up period $113(35.1 \%)$ of the 322 patients died (SOND [supraomohyoid neck dissection]: 53 cases, MRND [modified radical neck dissection]: 60 cases).

\section{Disease-free survival (or new disease, progression and mortality)}

The study reported data for disease-specific survival but we were unable to use them in an analysis. The study report stated, "There was no significant difference between the SOND [supraomohyoid neck dissection] group and the MRND [modified radical neck dissection] group in the 3-year disease-specific survival (DSS) rate (79.0\% vs. $76.9 \%, \mathrm{P}=0.659)$."

The Kaplan Meier survival curve for neck recurrence-free survival had insufficient information to calculate the HR. The study report stated, "By the Kaplan-Meier test, the patients in the SOND [supraomohyoid neck dissection] group had a better 3-year NCR [neck control rate] than those in the MRND [modified radical neck dissection] group, but the difference was not significant $(92.6 \%$ vs. $87.5 \%, \mathrm{P}=0.108) . "$

\section{Locoregional recurrence}

The trial did not report locoregional recurrence.

\section{Recurrence}

The trial did not report recurrence.

\section{Secondary outcomes}

There was some limited information on adverse events in the text. The study report stated, "There was a significant difference in the complication rates between both groups (SOND [supraomohyoid neck dissection] group vs. MRND [modified radical neck dissection] group: $13.0 \%$ vs. $21.9 \%, P=0.040$ ). The most frequent complication was wound infection." The report summarised other significant complications. The study assessed University of Washington Quality of Life Questionnaire (UW-QOL) scores for all disease-free survivors at one year after treatment (Deleyiannis 1997), scores from nine disease-specific domains appeared to show that $\mathrm{SOH}$ neck dissection was superior to modified RND in the domains of pain relief $(78.8 \%$ versus $75.2 \% ; P=0.013)$ and shoulder function $(81.1 \%$ versus $68.1 \% ; P<0.001)$, but not in any of the other domains.

\section{Comparison 7: selective neck dissection versus super-selective neck dissection}

See Summary of findings 7.

One trial at overall unclear risk of bias compared selective neck dissection versus super-selective neck dissection in participants with oral cavity cancer (T1 to T3 tumours; clinically negative neck nodes) (Rastogi 2018).

\section{Overall survival (or total mortality)}

The study did not report this outcome.

\section{Disease-free survival (or new disease, progression and mortality)}

The study did not report this outcome.

\section{Locoregional recurrence}

The study investigated locoregional recurrence for 2.5 years. Survival analysis (rate of recurrence) was measured using the Kaplan-Meier model (survival analysis regression model), however HRs could not be calculated from the data provided. The study report stated, "the $P$ value by Kaplan-Meier survival analysis was less than .05. Therefore, the SSND (super selective) group showed a lower rate of recurrence compared with the SND (selective group $(\mathrm{P}<.5) . "$

\section{Recurrence}

The study did not report recurrence.

\section{Secondary outcomes}

The study analysed data for shoulder morbidity subjectively and objectively. The results for both measures showed less shoulder morbidity and improved quality of life for superselective neck dissection compared with selective neck dissection. Only $P$ values were presented so we were unable to use the data provided. 
The study authors performed subjective analysis measuring shoulder morbidity using the Neck Dissection Quality of Life (ND-QOL) questionnaire. Data showed that the mean score for the super-selective neck dissection group (30.4) was significantly higher $(P=0.01)$ than for the selective neck dissection group (19.4).

The study authors stated that quality of life for the super-selective neck dissection group was significantly better than the selective neck dissection group based on the outcome of the ND-QOL questionnaire. There were no other data presented to confirm this position other than the scores on the ND-QOL questionnaire.

\section{DISCUSSION}

\section{Summary of main results}

This systematic review was undertaken to answer the question 'Does treatment with surgery improve the outcomes for patients with oral cavity and oropharyngeal cancers?' We included 12 RCTs with a combined total of 2300 randomised participants. Approximately 2148 of these participants had oral cavity cancers. None of the trials were at overall low risk of bias.

None of the included trials compared different surgical approaches to the removal of the primary tumour. Five of the included trials evaluated the timing of neck dissection surgery in the course of treatment and two included trials evaluated the extent of neck dissection.

- Comparison 1: elective neck dissection versus therapeutic (delayed) neck dissection: included five trials that compared elective neck dissection surgery undertaken at the same time as excision of the primary tumour with the option of excision of the primary alone, followed by subsequent neck dissection surgery if and when neck nodes showed clinical signs of cancer (therapeutic neck dissection). All participants had oral cavity cancers, specifically tongue or floor of mouth tumours, and clinically negative neck nodes. All the evidence was graded as very low certainty. One trial showed a difference in overall survival and disease-free survival after three and a half years of follow-up, favouring elective $\mathrm{SOH}$ neck dissection compared to therapeutic neck dissection. In two trials where the elective procedure was a RND, there was no difference between the elective and therapeutic groups with regard to either overall or disease-free survival. The fourth trial in this group did not report overall or disease-free survival. There was inconclusive evidence concerning the effect of elective neck dissection on locoregional disease recurrence; findings were mixed and the data were unsuitable for meta-analysis.

- Comparison 2: elective RND versus elective selective neck dissection: included two trials that compared elective radical (comprehensive) neck dissection with a selective neck dissection in participants with oral cavity cancers. One trial included only participants with clinically negative neck nodes and the other included those with movable positive neck nodes as well. There was no evidence from these two trials of a difference in overall survival between the two types of surgery, and in the single trial that reported disease-free survival and disease recurrence, there was no difference between the two types of surgery. All the evidence was very low certainty.

- Comparison 3: surgery plus radiotherapy versus radiotherapy alone: involved one trial that compared surgery plus postoperative radiotherapy and radiotherapy alone, but this trial was stopped early due to an unacceptably high death rate in the radiotherapy alone group. There was very low-certainty evidence of a difference in overall survival favouring the surgery plus radiotherapy group. These results should be interpreted with caution because the nature of the interim analysis on 35 participants ( $10 \%$ of planned recruitment) may have inflated the difference between the groups. Also, there were several protocol violations (more than half of the participants did not receive their radiotherapy as planned due to faulty machines), which may partially explain the poor outcome in the radiotherapy alone group.

- While there was very low-certainty evidence from these included trials that early or extensive dissection of the lymph nodes in the clinically negative neck reduced locoregional recurrence, there was no strong evidence of a difference in overall survival or disease-free survival. There was no information from these trials on quality of life of the people who had undergone the different neck dissection procedures.

- Comparison 4: PET-CT following chemoradiotherapy versus planned neck dissection either before or after chemoradiotherapy: involved one trial comparing PET-CT (with neck dissection only if no/incomplete response to chemoradiotherapy identified) versus planned neck dissection (either before or after chemoradiotherapy), there was very lowcertainty evidence of no difference in mortality. The trial did not provide usable data for the other outcomes.

- Comparison 5: surgery plus adjuvant radiotherapy versus chemotherapy: involved one trial comparing surgery plus adjunctive radiotherapy versus chemoradiotherapy. There were no useable data from this trial.

- Comparison 6: SOH neck dissection versus modified RND involved one trial comparing $\mathrm{SOH}$ neck dissection versus modified RND. There were no useable data from this trial.

- Comparison 7: selective neck dissection versus super-selective neck dissection involved one trial that compared super selective neck dissection versus selective neck dissection. There were no useable data from this trial.

\section{Overall completeness and applicability of evidence}

This review originally sought to evaluate the benefits of all surgical treatment modalities used alone or in conjunction with other treatment regimens such as radiotherapy, or chemotherapy and radiotherapy. However, this led to multiple treatment comparisons of studies that did not necessarily differ purely on the surgical treatment method. This review is one of a series of reviews in oral cancer looking at surgery, radiotherapy, chemotherapy and immunotherapy. Therefore, for this update, we modified the protocol for this review to include only studies that directly compared different surgical treatment modalities against one another, or compared surgery to a different treatment regimen such as radiotherapy, chemotherapy or immunotherapy. We removed all other studies from the updated review, and, where appropriate, incorporated them into the other oral cancer reviews (Furness 2011; Glenny 2010).

The inclusion criteria for this review specified that trials of surgery where participants had either oral cavity or oropharyngeal cancer would be included. However, for this update of the review, the search identified only 12 trials and 2148 of the total of 2300 participants in these trials had oral cavity cancers, most commonly 
in either the tongue or floor of mouth. The trials, each including between 35 and 564 participants, recruited participants over five decades between 1966 and 2017. There have been significant developments in both the surgical and adjuvant treatments for people with oral cavity cancer since the late 2000s and these are incompletely evaluated in this systematic review due to the lack of RCTs in this condition. It is encouraging to note that there are currently three large trials ongoing that will provide further information concerning the benefits and harms of different surgical options for neck dissection in people with oral cavity cancer (NCT00571883 (SEND); NCT01334320; Nichols 2013 (formerly NCT01590355)).

Only two of the included studies reported harms or adverse events to treatment, but neither presented outcomes per person (BHNCSG 1998; Robertson 1998). Aggressive surgery to remove the cancer and reduce the risk of recurrence has been associated with very significant adverse effects on both appearance and functions such as breathing, speech and swallowing. Less-aggressive surgery, such as selective lymph node dissection, is associated with a greater risk of recurrence, but preservation of function and appearance. Incorporation of quality of life outcomes into randomised trials is essential if the true benefits and harms of different types of surgery are to be evaluated. It is noteworthy that while some of the trials included in this review reported that some participants randomly allocated to surgery refused surgical treatment and were withdrawn from the trials, there was no report of the quality of life of these people compared to those included in the trials.

We identified no trials of surgery in people with oropharyngeal cancer, probably because the current therapeutic approach to oropharyngeal cancer is either radiotherapy or chemoradiotherapy. Since the late 2000s, the percentage of people with oropharyngeal cancer who test positive for HPV has increased steadily. It is now recognised that HPV status of people with oropharyngeal cancer is an important factor in their prognosis (Adelstein 2009; Brizel 2011). In updates of this review, we will undertake a subgroup analysis for the surgical management of HPV-related oral cavity cancer and the surgical management of
non-HPV related oral cavity cancer, provided there are a sufficient number of trials reporting this.

\section{Quality of the evidence}

The overall certainty of the evidence included in this systematic review was very low. All of the included trials were at either high or unclear risk of bias. Participants were recruited over five decades (1966 to 2017). For objective outcomes such as total mortality, we had planned that trials we assessed as adequate with regard to the domains of sequence generation, allocation concealment, complete outcome data and absence of selective reporting would be assessed as being at low risk of bias overall. None of the included studies met all these criteria. None of the trials included in this systematic review used, or reported using, blinding of either the participants or outcome assessors. It is recognised that blinding is difficult to maintain in trials of surgery and it may not be either possible, or indeed ethical, to blind trial participants. It is likely that many outcome assessments are performed by the clinicians treating the participants.

There has been substantial developments in the surgical and nonsurgical treatments for both oral and oropharyngeal cancers over recent years. Further objective assessments of current surgical treatments for these cancers are needed to inform both patients and clinicians about the benefits and risks of different treatments.

\section{Potential biases in the review process}

The search strategy was comprehensive with no language restrictions, and we clearly specified inclusion criteria for the review in line with the other reviews in this series (Furness 2011; Glenny 2010), so the risk of biased selection of studies was minimal.

Figure 3 provides an indication of the review authors' judgements about each risk of bias item presented as percentages across all included studies. The decision to look at blinding for overall survival (low risk of bias assessment), which is then used for all nine outcomes, is a source of bias in the review process.

\section{Figure 3. Risk of bias graph: review authors' judgements about each risk of bias item presented as percentages} across all included studies.

\section{Random sequence generation (selection bias)}

Allocation concealment (selection bias)

Blinding of outcome assessment (detection bias)

Incomplete outcome data (attrition bias)

Selective reporting (reporting bias)
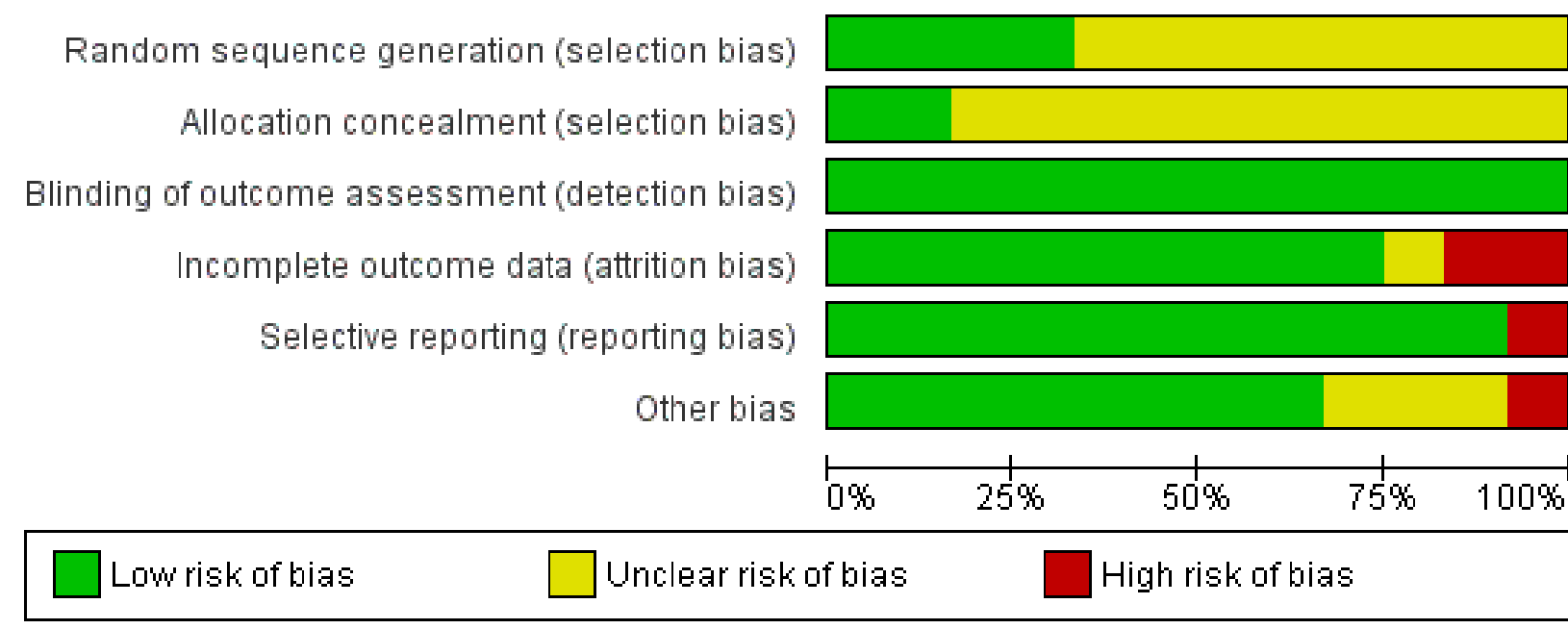


\section{Agreements and disagreements with other studies or reviews}

We found two reviews of treatment of neck dissection in the surgical treatment of oral cavity cancer based on the same included studies (Fasunla 2011; Kowalski 2007). Kowalski 2007 looked at dichotomous outcomes (percentages in each group) in three RCTs. No meta-analysis was undertaken and only the summary outcome estimates were noted, without regard to the variance of these. Their conclusions were based on "vote-counting."

Fasunla 2011 reviewed four RCTs and reported the dichotomous outcome of disease-specific death after approximately three years of follow-up. This review found that the RR of disease-specific death favoured elective neck dissection (RR $0.57,95 \% \mathrm{Cl} 0.36$ to 0.89 ).

We chose to use the outcome of overall survival/total mortality because we believe this is the more important outcome for patients, and we have used HRs where possible, as they have the advantage of incorporating all available information, including data from participants who failed to complete the trial, in the outcome. We look forward to the addition of data from the three ongoing trials identified to the next update of this review.

\section{A U THORS' CONCLUSIONS}

\section{Implications for practice}

This review includes 12 randomised controlled trials that evaluated neck dissection surgery in participants with oral cavity cancers. We found insufficient evidence to draw conclusions about elective neck dissection of clinically negative neck nodes at the time of removal of the primary tumour compared to therapeutic neck dissection. Two studies using radical neck dissection as the elective procedure did not find a difference between interventions, while one trial found that elective supraomohyoid neck dissection may be associated with increased overall and disease-free survival when compared to a therapeutic neck dissection. Three studies had inconclusive results for locoregional recurrence, and one found this was reduced with elective neck dissection. There is no evidence that elective radical neck dissection increases overall survival compared to more conservative neck dissection surgery. There is no evidence of a difference in mortality between PETCT surveillance following chemoradiotherapy versus planned ND (before or after chemoradiotherapy). Reporting of adverse events in all trials was poor and it was not possible to compare the quality of life of participants undergoing different surgeries. Available evidence for all comparisons and outcomes is very low certainty and results should be interpreted in light of this.

\section{Implications for research}

We would make the following recommendations for future research involving the surgical treatment of oral or oropharyngeal tumours.

- Trialists are encouraged to follow the CONSORT guidelines when reporting on their trials. Ideally, trials should report hazard ratios with $95 \%$ confidence intervals for survival data, or present data that allows for the calculation of this estimate of effect.

- Health-related quality of life is an important outcome measure that should be integral to all trials of oral cavity and oropharyngeal cancers.

- There should be a standardised and consistent reporting of adverse events and morbidity associated with treatment, with results reported per participant.

- Future trials of oral cavity and oropharyngeal cancers should report data based on the location of the primary tumour.

\section{ACK N O WLEDGEMENTS}

Thanks to Anne Littlewood for carrying out the searches for the review, Laura MacDonald for managing the editorial process, Anne Lawson for final copy editing and Fang Hua for translation of studies in Chinese. Thanks to Dr Chunjie Li, Dr Nicole Skoetz, Niall McGoldrick, Dr Ambika Parmar, Professor Tanya Walsh and Dr Martin McCabe for their comments on the draft review.

The review authors would particularly like to thank Professor Sanguineti, Professor Ang, Professor Rodrigo and Professor Mehanna for responding to our letters requesting further data.

This publication presents independent research commissioned by the National Institute for Health Research (NIHR) under its Programme Grants for Applied Research scheme (RPPG-0707-10034). The views expressed in this publication are those of the authors and not necessarily those of the National Health Service, the NIHR or the Department of Health. 


\section{RE F E R E N C E S}

\section{References to studies included in this review \\ BHNCSG 1998 \{published data only\}}

Brazilian Head and Neck Cancer Study Group. Results of a prospective trial on elective modified radical classical versus supraomohyoid neck dissection in the management of oral squamous carcinoma. American Journal of Surgery 1998;176(5):422-7.

\section{Bier 1994 \{published data only\}}

* Bier J. Radical neck dissection versus conservative neck dissection for squamous cell carcinoma of the oral cavity. Recent Results in Cancer Research 1994;134:57-62.

Bier J, Howaldt HP, Pitz H, 4th German-Austrian-Swiss Study Group therapy study. Prospective, randomized, clinical study of squamous cell cancer of the mouth: "Radical neck dissection versus conservative neck dissection". Fortschritte der Kiefer- und Gesichts-Chirurgie 1992;37:108-10.

Bier J, Schlums D, Metelmann H, Howaldt HP, Pitz H. A comparison of radical and conservative neck dissection. International Journal of Oral \& Maxillofacial Surgery 1993;22(2):102-7.

\section{D'Cruz 2015 \{published data only\}}

D'Cruz AK, Vaish R, Kapre N, Dandekar M, Gupta S, Hawaldar R, et al. Elective versus therapeutic neck dissection in nodenegative oral cancer. New England Journal of Medicine 2015;373(6):521-9. [DOI: 10.1056/NEJMoa1506007]

\section{Fakih 1989 \{published data only\}}

Fakih AR, Rao RS, Borges AM, Patel AR. Elective versus therapeutic neck dissection in early carcinoma of the oral tongue. American Journal of Surgery 1989;158(4):309-13.

* Fakih AR, Rao RS, Patel AR. Prophylactic neck dissection in squamous cell carcinoma of oral tongue: a prospective randomized study. Seminars in Surgical Oncology 1989;5(5):327-30.

\section{Guo 2014 \{published data only\}}

Guo CB, Feng Z, Zhang JG, Peng X, Cai ZG, Mao C, et al. Supraomohyoid neck dissection and modified radical neck dissection for clinically node-negative oral squamous cell carcinoma: a prospective study of prognosis, complications and quality of life. Journal of Craniofacial Surgery 2014;42(8):1885-90. [DOI: 10.1016/j.jcms.2014.07.007]

\section{Iyer 2015 \{published data only\}}

Iyer NG, Tan DS, Tan VK, Wang W, Hwang J, Tan N-C, et al. Randomized trial comparing surgery and adjuvant radiotherapy versus concurrent chemoradiotherapy in patients with advanced, nonmetastatic squamous cell carcinoma of the head and neck: 10-year update and subset analysis. Cancer 2015;121(10):1599-607.

\section{Kligerman 1994 \{published data only\}}

Kligerman J, Lima RA, Soares JR, Prado L, Dias FL, Freitas EQ, et al. Supraomohyoid neck dissection in the treatment of T1/
T2 squamous cell carcinoma of oral cavity. American Journal of Surgery 1994;168(5):391-4.

\section{Mehanna 2017 \{published data only\}}

* Mehanna H, McConkey CC, Rahman JK, Wong W-L, Smith AF, Nutting $C$, et al. PET-NECK a multicentre randomised phase III non-inferiority trial comparing a positron emission tomography-computerised tomography-guided watch-andwait policy with planned neck dissection in the management of locally advanced (N2/N3) nodal metastases in patients with squamous cell head and neck cancer. Health Technology Assessment 2017; Vol. 21:17. [DOI: 10.3310/hta21170]

Mehanna H, Wong W-L, McConkey CC, Rahman JK, Robinson M, Hartley AG, et al. PET-CT surveillance versus neck dissection in advanced head and neck cancer. New England Journal of Medicine 2016;374(15):1444-54. [DOI: 10.1056/NEJMoa1514493]

\section{Rastogi 2018 \{published data only\}}

Rastogi S, Sharma A, Choudhury R, Tripathi S, Al Wayli H, Amrithraj $A$, et al. Is superselective neck dissection safer than supraomohyoid neck dissection for oral carcinoma patients with NO neck in terms of shoulder morbidity and recurrence rate?. Journal of Oral and Maxillofacial Surgery 2018;76(3):647-55. [DOI: 10.1016/j.joms.2017.08.002]

Robertson 1998 \{published data only\}

Robertson AG, Soutar DS, Paul J, Webster M, Leonard AG, Moore KP, et al. Early closure of a randomized trial: surgery and postoperative radiotherapy versus radiotherapy in the management of intra-oral tumours. Clinical Oncology (Royal College of Radiologists (Great Britain)) 1998;10(3):155-60.

\section{Vandenbrouck 1980 \{published data only\}}

Vandenbrouck C, Sancho-Garnier H, Chassagne D, Saravane D, Cachin Y, Micheau C. Elective versus therapeutic radical neck dissection in epidermoid carcinoma of the oral cavity: results of a randomized clinical trial. Cancer 1980;46(2):386-90.

\section{Yuen 2009 \{published data only\}}

Yuen AP, Ho CM, Chow TL, Tang LC, Cheung WY, Ng RW, et al. Prospective randomized study of selective neck dissection versus observation for NO neck of early tongue carcinoma. Head \& Neck 2009;31(6):765-72.

\section{References to studies excluded from this review}

Abbade 2015 \{published data only\}

Abbade L, Gige T, Amaral V, Aquino S, Miot H. Higher recurrence rates of head and neck nodular basal cell carcinoma treated with topical photodynamic therapy (MAL-PDT) compared to surgical excision: a randomized controlled study. Journal of the American Academy of Dermatology 2015;72(5):AB185. [0190-9622]

\section{Ajmani 2017 \{published data only\}}

Ajmani GS, Nocon CC, Wang CH, Bhayani MK. Assessment of adjuvant therapy in resected head and neck cancer with high- 
risk features. Oral Oncology 2017;74:15-20. [DOI: 10.1016/ j.oraloncology.2017.09.005]

Ang 2001 \{published and unpublished data\}

Ang KK, Trotti A, Brown BW, Garden AS, Foote RL, Morrison WH, et al. Randomized trial addressing risk features and time factors of surgery plus radiotherapy in advanced head-and-neck cancer. International Journal of Radiation Oncology, Biology, Physics 2001;51(3):571-8.

\section{Batra 2016 \{published data only\}}

Batra J, Bekal RK, Byadgi S, Attresh G, Sambyal S, Vakade CD. Comparison of skin staples and standard sutures for closing incisions after head and neck cancer surgery: a double-blind, randomized and prospective study. Journal of Maxillofacial and Oral Surgery 2016;15(2):243-50. [DOI: 10.1007/s12663-015-0809y]

\section{Bernier 2004 \{published data only\}}

Bernier J, Domenge C, Ozsahin M, Matuszewska K, Lefebvre JL, Greiner RH, et al. Postoperative irradiation with or without concomitant chemotherapy for locally advanced head and neck cancer. New England Journal of Medicine 2004;350(19):1945-52.

\section{Bier 1981 \{published data only\}}

Bier J, Rapp HJ, Borsos T. Randomized clinical study on intratumoral BCG-cell wall preparation (CWP) therapy in patients with squamous cell carcinoma in the head and neck region. Cancer Immunology, Immunotherapy 1981;12(1):71-9.

\section{Cooper 2004 \{published data only\}}

Cooper JS, Pajak TF, Forastiere AA, Jacobs J, Campbell BH, Saxman SB, et al. Postoperative concurrent radiotherapy and chemotherapy for high-risk squamous-cell carcinoma of the head and neck. New England Journal of Medicine 2004;350(19):1937-44.

\section{Dean 2013 \{published data only\}}

Dean A, Alamillos F, Centella I, Garcia-Alvarez S. Neck dissection with the harmonic scalpel in patients with squamous cell carcinoma of the oral cavity. Journal of Cranio-maxillo-facial Surgery 2013;42(1):84-7. [DOI: 10.1016/j.jcms.2013.02.007]

\section{De Stefani 2002 \{published data only\}}

* De Stefani A, Forni G, Ragona R, Cavallo G, Bussi M, Usai A, et al. Improved survival with perilymphatic interleukin-2 in patients with resectable squamous cell carcinoma of the oral cavity and oropharynx. Cancer 2002;95(1):90-7.

De Stefani A, Valente G, Forni G, Lerda W, Ragona R, Cortesina G. Treatment of oral cavity and oropharynx squamous cell carcinoma with perilymphatic interleukin-2: clinical and pathologic correlations. Journal of Immunotherapy with Emphasis on Tumor Immunology 1996;19(2):125-33.

\section{Fan 2017 \{published data only\}}

Fan S, Zhong JL, Chen WX, Chen WL, Li QX, Wang YY, et al. Postoperative immune response and surgical stress in selective neck dissection: comparison between endoscopically assisted dissection and open techniques in CT1-2N0 oral squamous cell carcinoma. Journal of Cranio-maxillo-facial Surgery 2017;45(8):1112-6. [DOI: 10.1016/j.jcms.2016.11.021]

Fritz 2016 \{published data only\}

Fritz DK, Matthews TW, Chandarana SP, Nakoneshny SC, Dort JC. Harmonic scalpel impact on blood loss and operating time in major head and neck surgery: a randomized clinical trial. Journal of Otolaryngology - Head \& Neck Surgery 2016;45(58):1-6. [DOI: 10.1186/s40463-016-0173-z]

\section{Funahara 2017 \{published data only\}}

Funahara M, Yanamoto S, Ueda M, Suzuki T, Ota Y, Nishimaki F, et al. Prevention of surgical site infection after oral cancer surgery by topical tetracycline: results of a multicenter randomized controlled trial. Medicine 2017;96(48):1-6. [DOI: 10.1097\%2FMD.0000000000008891]

\section{George 2014 \{published data only\}}

George JR, Yom SS, Wang SJ. Improved outcomes in adjuvant radiotherapy for oral cavity carcinoma at an academic center: a matched-pair analysis. Laryngoscope 2014;124(7):1603-8. [DOI: 10.1002/lary.24552]

\section{Gundale 2017 \{published data only\}}

Gundale A, Rajdeep, Vasanthan L, Tirkey AK, Rajinikanth J. A randomised controlled trial of intraoperative brief electrical stimulation vs no stimulation of spinal accessory nerve for prevention of shoulder dysfunction after oncologic neck dissection in oral cavity squamous cell carcinomas-an interim report. Head \& Neck 2017; Vol. 39, issue S1:224.

\section{Hintz 1979a \{published data only\}}

Hintz B, Charyulu K, Chandler JR, Sudarsanam A, Garciga C. Randomized study of local control and survival following radical surgery or radiation therapy in oral and laryngeal carcinomas. Journal of Surgical Oncology 1979;12(1):61-74.

\section{Hintz 1979b \{published data only\}}

Hintz B, Charyulu K, Chandler JR, Sudarsanam A, Garciga C. Randomized study of control of the primary tumor and survival using preoperative radiation, radiation alone, or surgery alone in head and neck carcinomas. Journal of Surgical Oncology 1979;12(1):75-85.

\section{Howard 2016 \{published data only\}}

Howard J, Masterson L, Dwivedi RC, Riffat F, Benson R, Jefferies $S$, et al. Minimally invasive surgery versus radiotherapy/chemoradiotherapy for small-volume primary oropharyngeal carcinoma. Cochrane Database of Systematic Reviews 2016, Issue 12. [DOI: 10.1002/14651858.CD010963.pub2]

\section{Jinyun 2015 \{published data only\}}

Jinyun L, Wenxiao H, Jie C, Ronghua B. Clinical application of the combined radical operation without breaking lower lip and mandible for tongue and lingual root carcinoma. Chinese Journal of Otorhinolaryngology Head and Neck Surgery 2015;50(3):225-9. [10.3760/cma. j. issn. 1673-0860. 2015. 03. 010; PUBMED: 26268496] 
Kramer 1987 \{published data only\}

Kramer S, Gelber RD, Snow JB, Marcial VA, Lowry LD, Davis LW, et al. Combined radiation therapy and surgery in the management of advanced head and neck cancer: final report of study 73-03 of the Radiation Therapy Oncology Group. Head \& Neck Surgery 1987;10(1):19-30.

\section{Lam 2001 \{published data only\}}

Lam P, Yuen AP, Ho CM, Ho WK, Wei WI. Prospective randomized study of post-operative chemotherapy with levamisole and UFT for head and neck carcinoma. European Journal of Surgical Oncology 2001;27(8):750-3.

\section{Laramore 1992 \{published data only\}}

Aref A, Berkey BA, Schwade JG, Ensley J, Schuller DE, Haselow RE, et al. The influence of beam energy on the outcome of postoperative radiotherapy in head and neck cancer patients: secondary analysis of RTOG 85-03. International Journal of Radiation Oncology, Biology, Physics 2000;47(2):389-94.

Jacobs JR, Casiano RR, Schuller DE, Pajak TF, Laramore GE, alSarraf M. Chemotherapy as predictor of compliance. Journal of Surgical Oncology 1994;55(3):143-8.

* Laramore GE, Scott CB, al-Sarraf M, Haselow RE, Ervin TJ, Wheeler R, et al. Adjuvant chemotherapy for resectable squamous cell carcinomas of the head and neck: report on Intergroup Study 0034. International Journal of Radiation Oncology, Biology, Physics 1992;23(4):705-13.

\section{Lawrence 1974 \{published data only\}}

Lawrence W Jr, Terz JJ, Rogers C, King RE, Wolf JS, King ER. Proceedings: preoperative irradiation for head and neck cancer: a prospective study. Cancer 1974;33(2):318-23.

Licitra 2001 \{published data only\}

Licitra L, Grandi C, Cavina R, Guzzo M, Mariani L, Lo Vullo S, et al. Primary chemotherapy (pCT) for patients with operable oral cavity cancer: results of a randomized study. Proceedings of the American Society of Clinical Oncology (ASCO) 2001;20:Abstract 890.

\section{Lin 2016 \{published data only\}}

Lin WJ, Wang CC, Jiang RS, Huang YC, Ho HC, Liu SA. A prospective randomised trial of LigaSure Small Jaw ${ }^{\circledast}$ versus conventional neck dissection in head and neck cancer patients. Clinical Otolaryngology 2016;42(2):245-51.

\section{Luboinski 1985 \{published data only\}}

Luboinski B. Preliminary results of a randomized study on preoperative intra-arterial chemotherapy combined with surgery and irradiation for carcinomas of the floor of the mouth. Progress in Clinical and Biological Research 1985;201:199-203.

\section{Maipang 1995 \{published data only\}}

Maipang T, Maipang M, Geater A, Panjapiyakul C, Watanaarepornchai S, Punperk S, et al. Combination chemotherapy as induction therapy for advanced resectable head and neck cancer. Journal of Surgical Oncology 1995;59(2):80-5.

\section{McCaul 2012 \{published data only\}}

McCaul JA, Kulkami R, Gouldesbrough D, Boye T, Sutton D, Abdel-Galil K, et al. LIHNCS; randomised control trial in oral and maxillofacial surgery interim data and recruitment report. British Journal of Oral \& Maxillofacial Surgery 2012;50(1 Suppl):S22. [DOI: 10.1016/j.bjoms.2012.04.203]

McCaul 2017 \{published data only\}

McCaul JA, McMahon JM, Quantrill J, Gilbert K, Mehanna HM, Shaw R, et al. LIHNCS: Lugol's iodine in head and neck cancer surgery - a multi-centre, randomised, controlled trial assessing the effectiveness of Lugol's iodine to assist excision of moderate dysplasia, severe dysplasia and carcinoma in-situ at mucosal resection margin of oral and oropharyngeal squamous cell carcinoma. Journal of Clinical Oncology 2017;35(15 Suppl):6065. [DOI: 10.1200/JCO.2017.35.15_suppl.6065]

\section{Minkovich 2011 \{published data only\}}

Minkovich L, Djaiani G, McCluskey SA, Mitsakakis N, Gilbert RW, Beattle WS. Frequent malpositions of peripherally inserted central venous catheters in patients undergoing head and neck surgery [Mauvais positionnements frequents des catheters veineux centraux inseres par voie peripherique chez les patients subissantune chirurgie au niveau de la tete et du cou]. Canadian Journal of Anesthesia 2011;58:709-13.

\section{Mohr 1994 \{published data only\}}

Mohr C, Bohndorf W, Carstens J, Harle F, Hausamen JE, Hirche $\mathrm{H}$, et al. Preoperative radiochemotherapy and radical surgery in comparison with radical surgery alone. A prospective, multicentric, randomized DOSAK study of advanced squamous cell carcinoma of the oral cavity and the oropharynx (a 3year follow-up). International Journal of Oral and Maxillofacial Surgery 1994;23(3):140-8.

\section{Neifeld 1985 \{published data only\}}

Neifeld JP, Terz JJ, Kaplan AM, Lawrence W Jr. Adjuvant corynebacterium parvum immunotherapy for squamous cell epitheliomas of the oral cavity, pharynx, and larynx. Journal of Surgical Oncology 1985;28(2):137-45.

\section{Oswal 2017 \{published data only\}}

Oswal S, Borle R, Bhola N, Jadhav A, Surana S, Oswal R. Surgical staples: a superior alternative to sutures for skin closure after neck dissection - a single-blinded prospective randomized clinical study. Journal of Oral and Maxillofacial Surgery 2017;75(12):2707.e1-6. [DOI: 10.1016/j.joms.2017.08.004]

\section{Paccagnella 1994 \{published data only\}}

Paccagnella A, Orlando A, Marchiori C, Zorat PL, Cavaniglia G, Sileni VC, et al. Phase III trial of initial chemotherapy in stage III or IV head and neck cancers: a study by the Gruppo di Studio sui Tumori della Testa e del Collo. Journal of the National Cancer Institute 1994;86(4):265-72.

\section{Poh 2011 \{published data only\}}

Poh CF, Durham JS, Brasher PM, Anderson DW, Berean KW, MacAulay CE, et al. Canadian Optically-guided approach for Oral Lesions Surgical (COOLS) trial: study protocol for a randomized controlled trial. BMC Cancer 2011;11:462. [DOI: 10.1186/1471-2407-11-462 
Rao 1991 \{published data only\}

Rao RS, Parikh DM, Parikh HK, Bhansali MB, Deshmane VH, Fakih AR. Perioperative chemotherapy in patients with oral cancer. American Journal of Surgery 1994;168(3):262-7.

* Rao RS, Parikh DM, Parikh HK, Bhansali MB, Fakih AR. Perioperative chemotherapy in oral cancer. Journal of Surgical Oncology 1991;47(1):21-6.

\section{Rentschler 1987 \{published data only\}}

Rentschler RE, Wilbur DW, Petti GH, Chonkich GD, Hilliard DA, Camacho ES, et al. Adjuvant methotrexate escalated to toxicity for resectable stage III and IV squamous head and neck carcinomas-a prospective, randomized study. Journal of Clinical Oncology 1987;5(2):278-85.

\section{Richard 1991 \{published data only\}}

Richard JM, Kramar A, Molinari R, Lefebvre JL, Blanchet F, Jortay A, et al. Randomised EORTC head and neck cooperative group trial of preoperative intra-arterial chemotherapy in oral cavity and oropharynx carcinoma. European Journal of Cancer 1991;27(7):821-7.

\section{Sanguineti 2005 \{published and unpublished data\}}

Sanguineti G, Richetti A, Bignardi M, Corvo R, Gabriele P, Sormani MP, et al. Accelerated versus conventional fractionated postoperative radiotherapy for advanced head and neck cancer: results of a multicenter phase III study. International Journal of Radiation Oncology, Biology, Physics 2005;61(3):762-71.

\section{Schuller 1988 \{published data only\}}

* Schuller DE, Metch B, Stein DW, Mattox D, McCracken JD. Preoperative chemotherapy in advanced resectable head and neck cancer: final report of the Southwest Oncology Group. Laryngoscope 1988;98(11):1205-11.

Schuller DE, Stein DW, Metch B. Analysis of treatment failure patterns. A Southwest Oncology Group Study. Archives of Otolaryngology - Head \& Neck Surgery 1989;115(7):834-6.

\section{Szabo 1999 \{published data only\}}

Szabo G, Kreidler J, Hollmann K, Kovacs A, Nemeth G, Nemeth Z, et al. Intra-arterial preoperative cytostatic treatment versus preoperative irradiation: a prospective, randomized study of lingual and sublingual carcinomas. Cancer 1999;86(8):1381-6.

\section{Szpirglas 1978 \{published data only\}}

Szpirglas H, Chastang C, Bertrand JC. Adjuvant treatment of tongue and floor of the mouth cancers. Recent Results in Cancer Research 1978;68:309-17.

\section{Terz 1981 \{published data only\}}

Terz JJ, King ER, Lawrence W Jr. Preoperative irradiation for head and neck cancer: results of a prospective study. Surgery 1981;89(4):449-53.

\section{Tingting 2016 \{published data only\}}

Tingting L, Canhua J, Jie C, Limeng W, Ruipu Z, Xinchun J. Application of carbon nanoparticles as lymph node tracers in patients with cNO lingual squamous cell carcinoma undergoing neck dissection. West China Journal of Stomatology 2016;34(4):408-13. [DOI: 10.7518/hxkq.2016.04.018]

Uppal 2012 \{published data only\}

Uppal A, Kakar FD, Uppal SA, Majeed R. Comparison of the complication between the radical neck dissection \& selective neck dissection for the patient of oral squamous cell carcinoma. Medical Forum Monthly 2012;23(1):31-4.

Verma 2017 \{published data only\}

Verma RK, Mathiazhagan A, Panda NK. Neck dissection with harmonic scalpel and electrocautery? A randomised study. Auris Nasus Larynx 2017;44(5):590-5. [DOI: 10.1016/j.anl.2016.11.004]

\section{Volling 1999 \{published data only\}}

Volling P, Schroder M. Preliminary results of a prospective randomized study of primary chemotherapy in carcinoma of the oral cavity and pharynx. HNO 1995;43(2):58-64.

* Volling P, Schroder M, Eckel H, Ebeling O, Stennert E. Results of a prospective randomized trial with induction chemotherapy for cancer of the oral cavity and tonsils. HNO 1999;47(10):899-906.

Volling P, Schroder M, Muller RP, Ebeling O, Quirin R, Stennert E, et al. Induction chemotherapy in primary resectable head and neck tumors: a prospective randomized trial. International Journal of Oncology 1994;4(4):909-14.

\section{Walen 2011 \{published data only\}}

Walen SG, Rudmik LR, Dixon E, Matthews TW, Nakoneshny SC, Dort JC. The utility of the harmonic scalpel in selective neck dissection: a prospective, randomized trial. Otolaryngology and Head and Neck Surgery 2011;144(6):894-9. [DOI: $10.1177 / 0194599811403874]$

\section{Weissler 1992 \{published data only\}}

Weissler MC, Melin S, Sailer SL, Qaqish F, Rosenman JG, Pillsbury HC. Simultaneous chemoradiation in the treatment of advanced head and neck cancer. Archives of Otolaryngology Head \& Neck Surgery 1992;118(8):806-10.

\section{Zhang 2010 \{published data only\}}

Zhang F, Yang K, Li Y, Chen DR, Xiang L. Comparison of surgical effects on patients with oral squamous cell carcinoma in cNO stage operated in two kinds of neck dissection. Stomatology 2010; Vol. 30, issue 2:98-100.

\section{Zhong 2013 \{published data only\}}

Zhong LP, Zhang CP, Ren GX, Guo W, William WN Jr, Sun J, et al. Randomized phase III trial of induction chemotherapy with docetaxel, cisplatin, and fluorouracil followed by surgery versus up-front surgery in locally advanced resectable oral squamous cell carcinoma. Journal of Clinical Oncology 2013;31(6):744-51. [DOI: 10.1200/jco.2012.43.8820]

\section{Zhong 2015 \{published data only\}}

Zhong LP, Zhang CP, Ren GX, Guo W, William WN Jr, Hong CS, et al. Long-term results of a randomized phase III trial of TPF induction chemotherapy followed by surgery and radiation in locally advanced oral squamous cell carcinoma. Oncotarget 2015;6(21):18707-14. [DOI: 10.18632/oncotarget.4531] 


\section{References to ongoing studies}

NCT00571883 (SEND) \{published data only\}

NCT00571883. The role of selective neck dissection used electively in patients with early oral squamous cell carcinoma (1-3cm primary size) and no clinical evidence of lymph node metastases in the neck (SEND). clinicaltrials.gov/ct2/show/ NCT00571883 Date first received 12 December 2007.

NCT01334320 \{published data only\}

NCT01334320. Survival benefit of elective neck dissection in T1,2 N0 M0 oral squamous cell carcinoma. clinicaltrials.gov/ct2/ show/NCT01334320 Date first received: 10 April 2015.

Nichols 2013 (formerly NCT01590355) \{published data only\} Nichols AC, Yoo J, Hammond AJ, Fung K, Winquist E, Read N, et al. Early-stage squamous cell carcinoma of the oropharynx: radiotherapy vs. trans-oral robotic surgery (ORATOR) study protocol for a randomized phase II trial. BMC Cancer 2013;13(1):1-9. [DOI: 10.1186/1471-2407-13-133]

\section{Additional references}

\section{Adelstein 2009}

Adelstein DJ, Ridge JA, Gillison ML, Chaturvedi AK, D'Souza G, Gravitt PE, et al. Head and neck squamous cell cancer and the human papillomavirus: summary of a National Cancer Institute State of the Science Meeting; 2008 Nov 9-10; Washington (DC). Head \& Neck 2009; Vol. 31, issue 11:1393-422.

\section{Attner 2010}

Attner P, Du J, Nasman A, Hammarstedt L, Ramqvist T, Lindholm J, et al. The role of human papillomavirus in the increased incidence of base of tongue cancer. International Journal of Cancer 2010;126(12):2879-84.

\section{Batsakis 1999}

Batsakis JG. Surgical excision margins: a pathologist's perspective. Advances in Anatomic Pathology 1999;6(3):140-8.

\section{Blanchard 2011}

Blanchard P, Baujat B, Holostenco V, Bourredjem A, Baey C, Bourhis $\mathrm{J}$, et al. Meta-analysis of chemotherapy in head and neck cancer (MACH-NC): a comprehensive analysis by tumour site. Radiotherapy Oncology 2011;100(1):33-40.

\section{Brennan 2017}

Brennan PA, Bradley KL, Brands M. Intensity-modulated radiotherapy in head and neck cancer - an update for oral and maxillofacial surgeons. British Journal of Oral and Maxillofacial Surgery 2017;55:770-4.

\section{Brizel 1998}

Brizel DM, Albers ME, Fisher SR, Scher RL, Richtsmeier WJ, Hars V, et al. Hyperfractionated irradiation with or without concurrent chemotherapy for locally advanced head and neck cancer. New England Journal of Medicine 1998;338:1798-804.

\section{Brizel 2011}

Brizel DM, Lydiatt W, Colevas AD. Controversies in the locoregional management of head and neck cancer. Journal of National Comprehensive Cancer Network 2011;9(6):653-62.

\section{Carew 2003}

Carew JF, Singh B, Shah JP. Cervical lymph nodes. In: Shah JP, Johnson NW, Batsakis JG editor(s). Oral Cancer. London: Martin Dunitz, 2003:215-49.

\section{Chaturvedi 2008}

Chaturvedi AK, Engels EA, Anderson WF, Gillison ML. Incidence trends for human papillomavirus-related and -unrelated oral squamous cell carcinomas in the United States. Journal of Clinical Oncology 2008;26:612-9.

\section{Chaturvedi 2011}

Chaturvedi AK, Engels EA, Pfeiffer RM, Hernandez BY, Xiao W, Kim E, et al. Human papillomavirus and rising oropharyngeal cancer incidence in the United States. Journal of Clinical Oncology 2011;29:4294-301.

\section{Chaturvedi 2013}

Chaturvedi AK, Anderson WF, Lortet-Tieulent J, Curado MP, Ferlay J, Franceschi S, et al. Worldwide trends in incidence rates for oral cavity and oropharyngeal cancers. Journal of Clinical Oncology 2013;31(36):4550-9.

\section{Chaturvedi 2015}

Chaturvedi AK, Graubard BI, Broutian T, Pickard RK, Tong ZY, Xiao W, et al. NHANES 2009-2012 findings: association of sexual behaviors with higher prevalence of oral oncogenic human papillomavirus infections in U.S. men. Cancer Research 2015;75:2468-77.

\section{Conway 2008}

Conway DI, Petticrew M, Marlborough H, Berthiller J, Hashibe M, Macpherson LM. Socioeconomic inequalities and oral cancer risk: a systematic review and meta-analysis of case-control studies. International Journal of Cancer 2008;122(12):2811-9.

\section{Conway 2015}

Conway DI, Brenner DR, McMahon AD, Macpherson LM, Agudo A, Ahrens W, et al. Estimating and explaining the effect of education and income on head and neck cancer risk: INHANCE consortium pooled analysis of 31 case-control studies from 27 countries. International Journal of Cancer 2015;136(5):1125-39.

\section{D'Souza 2007}

D'Souza G, Kreimer AR, Viscidi R, Pawlita M, Fakhry C, Koch WM, et al. Case-control study of human papillomavirus and oropharyngeal cancer. New England Journal of Medicine 2007;356(19):1944-56.

\section{Day 1992}

Day GL, Blot WJ. Second primary tumours in patients with oral cancer. Cancer 1992;70(1):14-9. 


\section{Deleyiannis 1997}

Deleyiannis FW, Weymuller EA, Coltrera MD. Quality of life of disease-free survivors of advanced (stage III or IV) oropharyngeal cancer. Head and Neck 1997;19(6):466-73.

\section{Dias 2001}

Dias FL, Kligerman J, Matos De Sa G, Arcuri RA, Freitas EQ, Farias T, et al. Elective neck dissection versus observation in stage I squamous carcinomas of the tongue and floor of the mouth. Otolaryngology, Head and Neck Surgery 2001;125:23-9.

\section{Duprez 2017}

Duprez F, Berwouts D, De Neve W, Bonte K, Boterberg T, Deron P, et al. Distant metastases in head and neck cancer. Head \& Neck 2017;39(9):1733-43.

\section{Ebrahimi 2012}

Ebrahimi A, Ashford BG, Clark JR. Improved survival with elective neck dissection in thick early-stage oral squamous cell carcinoma. Head \& Neck 2012;34(5):709-16.

\section{Ewing 1952}

Ewing MR, Martin H. Disability following radical neck dissection. An assessment based on the postoperative evaluation of 100 patients. Cancer 1952;5:873-83.

\section{Fakhry 2006}

Fakhry C, Gillison ML. Clinical implications of human papillomavirus in head and neck cancers. Journal of Clinical Oncology 2006;24(17):2606-11.

\section{Fakhry 2008}

Fakhry C, Westra WH, Li S, Cmelak A, Ridge JA, Pinto H, et al. Improved survival of patients human papillomavirus - positive head and neck squamous cell carcinoma in a prospective clinical trial. Journal of the National Cancer Institute 2008;100(4):261-9.

\section{Fasunla 2011}

Fasunla AJ, Greene BH, Timmesfeld N, Wiegand S, Werner JA, Sesterhenn AM. A meta-analysis of the randomized controlled trials on elective neck dissection versus therapeutic neck dissection in oral cavity cancers with clinically node-negative neck. Oral Oncology 2011;47(5):320-4.

\section{Ferlay 2013}

Ferlay J, Soerjomataram I, Ervik M, Dikshit R, Eser S, Mathers C, et al. Cancer incidence and mortality worldwide: IARC CancerBase. International Agency for Research on Cancer GLOBOCAN 2012 v1.0 2013; Vol. 11.

\section{Freedman 2007}

Freedman ND, Abnet CC, Leitzmann MF, Hollenbeck AR, Schatzkin A. Prospective investigation of the cigarette smoking-head and neck cancer association by sex. Cancer 2007;110(7):1593-601.

\section{Furness 2011}

Furness S, Glenny AM, Worthington HV, Pavitt S, Oliver R, Clarkson JE, et al. Interventions for the treatment of oral cavity and oropharyngeal cancer: chemotherapy.
Cochrane Database of Systematic Reviews 2011, Issue 4. [DOI: 10.1002/14651858.CD006386.pub3]

\section{Gillison 2000}

Gillison ML, Koch WM, Capone RB, Spafford M, Westra WH, Wu L, et al. Evidence for a causal association between human papillomavirus and a subset of head and neck cancers. Journal of National Cancer Institute 2000;92:709-20.

\section{Gillison 2007}

Gillison ML. Current topics in the epidemiology of oral cavity and oropharyngeal cancers. Head \& Neck 2007;29:779-92.

\section{Glenny 2010}

Glenny AM, Furness S, Worthington HV, Conway DI, Oliver R, Clarkson JE, et al. Interventions for the treatment of oral cavity and oropharyngeal cancer: radiotherapy. Cochrane Database of Systematic Reviews 2010, Issue 12. [DOI: 10.1002/14651858.CD006387.pub2]

\section{Gupta 2014}

Gupta B, Johnson NW. Systematic review and meta-analysis of association of smokeless tobacco and of betel quid without tobacco with incidence of oral cancer in South Asia and the Pacific. PloS One 2014;9(11):e113385.

\section{Haddadin 2000}

Haddadin KJ, Soutar DS, Webster MH, Robertson AG, Oliver RJ, MacDonald DG. Natural history and patterns of recurrence of tongue tumours. British Journal of Plastic Surgery 2000;53(4):279-85.

\section{Higgins 2011}

Higgins JP, Green S, editor(s). Cochrane Handbook for Systematic Reviews of Interventions version 5.1.0 (updated March 2011). The Cochrane Collaboration, 2011. Available from handbook.cochrane.org.

\section{Holden 2018}

Holden AM, Sharma D, Schilling C, Gnanasegaran G, Odell EW, Sassoon I, et al. Biopsy of the sentinel lymph node in oral squamous cell carcinoma: analysis of error in 100 consecutive cases. British Journal of Oral and Maxillofacial Surgery 2018;56(7):615-20. [DOI: 10.1016/j.bjoms.2018.06.019]

\section{Holsinger 2015}

Holsinger FC, Ferris RL. Transoral endoscopic head and neck surgery and its role within the multidisciplinary treatment paradigm of oropharynx cancer: robotics, lasers and clinical trials. Journal of Clinical Oncology 2015;33(29):3285-92.

\section{Hughes 1993}

Hughes CJ, Gallo O, Spiro RH, Shah JP. Management of occult neck metastases in oral cavity squamous carcinoma. American Journal of Surgery 1993;166(4):380-3.

\section{Hughes 2012}

Hughes C, Homer J, Bradley P, Nutting C, Ness A, Persson M, et al. An evaluation of current services available for people diagnosed with head and neck cancer in the UK (2009-2010). Clinical Oncology 2012;24(10):187-9. 


\section{Kowalski 2007}

Kowalski LP, Sanabria A. Elective neck dissection in oral carcinoma: a critical review of the evidence. Acta Otorhinolaryngologica Italica 2007;27(3):113-7.

\section{La Vecchia 1997}

La Vecchia C, Tavani A, Franceschi S, Levi F, Corrao G, Negri E. Epidemiology and prevention of oral cancer. Oral Oncology 1997;33(5):302-12.

\section{Lefebvre 2011}

Lefebvre C, Manheimer E, Glanville J. Chapter 6: Searching for studies. In: Higgins JP, Green S, editor(s). Cochrane Handbook for Systematic Reviews of Interventions Version 5.1.0 (updated March 2011). The Cochrane Collaboration, 2011. Available from handbook.cochrane.org.

\section{Licitra 2006}

Licitra L, Perrone F, Bossi P, Suardi S, Mariani L, Artusi R, et al. High-risk human papillomavirus affects prognosis in patients with surgically treated oropharyngeal squamous cell carcinoma. Journal of Clinical Oncology 2006;24(36):5630-6.

\section{Lo Nigro 2017}

Lo Nigro C, Denaro N, Merlotti A, Merlano M. Head and neck cancer: improving outcomes with a multidisciplinary approach. Cancer Management and Research 2017;18(9):363-71.

\section{Louie 2015}

Louie KS, Mehanna H, Sasieni P. Trends in head and neck cancers in England from 1995 to 2011 and projections up to 2025. Oral Oncology 2015;51(4):341-8.

\section{Macfarlane 1995}

Macfarlane GJ, Zheng T, Marshall JR, Boffetta P, Niu S, Brasure J, et al. Alcohol, tobacco, diet and the risk of oral cancer: a pooled analysis of three case-control studies. European Journal of Cancer. Part B, Oral Oncology 1995;31B(3):181-7.

\section{McGurk 2005}

McGurk M, Vhan C, Jones J, O'Regan E, Sherriff M. Delay in diagnosis and its effect on outcome in head and neck cancer. British Journal of Oral and Maxillofacial Surgery 2005;43(4):281-4.

\section{NICE 2018}

National Institute for Health and Care Excellence. Cancer of the upper aerodigestive tract: assessment and management in people aged 16 and over. www.nice.org.uk/guidance/ng36 (accessed prior to 6 December 2018). [www.nice.org.uk/ guidance/ng36]

\section{Paleri 2016}

Paleri V, Urbano TG, Mehanna H, Repanos C, Lancaster J, Roques T, et al. Management of neck metastases in head and neck cancer: United Kingdom National Multidisciplinary Guidelines. Journal of Laryngology and Otology 2016;130(Suppl S2):S161-9. [DOI: 10.1017/S002221511600058X]

\section{Parkin 2005}

Parkin DM, Bray F, Ferlay J, Pisani P. Global cancer statistics, 2002. CA: a Cancer Journal for Clinicians 2005;55(2):74-108.

\section{Parmar 1998}

Parmar MK, Torri V, Stewart L. Extracting summary statistics to perform meta-analysis of the published literature for survival endpoints. Statistics in Medicine 1998;17(24):2815-34.

\section{Parsons 2002}

Parsons JT, Mendenhall WM, Stringer SP, Amdur RJ, Hinerman RW, Villaret DB, et al. Squamous cell carcinoma of the oropharynx: surgery, radiation therapy, or both. Cancer 2002;94(11):2967-80.

\section{Partridge 2000}

Partridge M, Li SR, Pateromichelakis S, Francis R, Phillips E, Huang $\mathrm{XH}$, et al. Detection of minimal residual cancer to investigate why oral tumors recur despite seemingly adequate treatment. Clinical Cancer Research 2000;6(7):2718-25.

\section{Purkayastha 2016}

Purkayastha M, McMahon AD, Gibson J, Conway DI. Trends of oral cavity, oropharyngeal and laryngeal cancer incidence in Scotland (1975-2012) - a socioeconomic perspective. Oral Oncology 2016;61:70-5.

\section{Robbins 2002}

Robbins KT, Clayman G, Levine PA, Medina J, Sessions R, Shaha A, et al. Neck dissection classification update: revisions proposed by the American Head and Neck Society and the American Academy of Otolaryngology-Head and Neck Surgery. Archives of Otolaryngology - Head \& Neck Surgery 2002;128(7):751-8.

\section{Ryerson 2008}

Ryerson AB, Peters EB, Coughlin SS, Chen VW, Gillison ML, Reichman ME, et al. Burden of potentially human papillomavirus-associated cancers of the oropharynx and oral cavity in the US. Cancer 2008;113(10 Suppl):2901-9.

\section{Schilling 2015}

Schilling C, Stoeckli SJ, Haerle SK, Broglie MA, Huber GF, Sorensen JA, et al. Sentinel European Node Trial (SENT): 3-year results of sentinel node biopsy in oral cancer. European Journal of Cancer 2015;51:2777-84.

\section{Schilling 2017}

Schilling C, Shaw R, Schache A, McMahon J, Chegini S, Kerawala $C$, et al. Sentinel lymph node biopsy for oral squamous cell carcinoma. Where are we now?. British Journal of Oral and Maxillofacial Surgery 2017;55:757-62.

\section{Shah 1990}

Shah JP. Cervical lymph node metastases - diagnostic, therapeutic, and prognostic implications. Oncology (Williston Park, N.Y.) 1990;4(10):61-9. 


\section{Simard 2014}

Simard EP, Torre LA, Jemal A. International trends in head and neck cancer incidence rates: differences by country, sex and anatomic site. Oral Oncology 2014;50(5):387-403.

\section{Stewart 2014}

Stewart B, Wild CP, editor(s). World cancer report. International Agency for Research on Cancer, WHO 2014.

\section{Studer 2007}

Studer G, Zwahlen RA, Graetz KW, Davis BJ, Glanzmann C. IMRT in oral cavity cancer. Radiation Oncology 2007;2(16):1-7.

\section{Sturgis 2007}

Sturgis EM, Cinciripini PM. Trends in head and neck cancer incidence in relation to smoking prevalence. Cancer 2007;110(7):1429-35.

\section{Sutton 2003}

Sutton DN, Brown JS, Rogers SN, Vaughan ED, Woolgar JA. The prognostic implications of the surgical margin in oral squamous cell carcinoma. International Journal of Oral and Maxillofacial Surgery 2003;32(1):30-4.

\section{Tapia 2011}

Tapia JL, Goldberg LJ. The challenges of defining oral cancer: analysis of an ontological approach. Head and Neck Pathology 2011;5:376-84.

\section{Torre 2015}

Torre LA, Bray F, Siegel RL, Ferlay J, Lortet-Tieulent J, Jemal A. Global cancer statistics, 2012. CA: a Cancer Journal for Clinicians 2015;65(2):87-108.

\section{Umeda 2010}

Umeda M, Shigeta T, Takahashi H, Oguni A, Katakoa T, Minamikawa T, et al. Shoulder mobility after spinal accessory nerve-sparing modified radical neck dissection in oral cancer patients. Oral Surgery, Oral Medicine, Oral Pathology, Oral Radiology, and Endodontics 2010;109:820-4.

\section{Warnakulasuriya 2009}

Warnakulasuriya S. Global epidemiology of oral and oropharyngeal cancer. Oral Oncology 2009;45(4-5):309-16.

\section{CHARACTERISTICS OF STUDIES}

Characteristics of included studies [ordered by study ID]

\section{WHO 1990}

World Health Organization. International Classification of Diseases for Oncology (ICD-O). 2nd Edition. Geneva: World Health Organization, 1990.

\section{Winn 2015}

Winn DM, Lee YC, Hashibe M, Boffetta P. The INHANCE consortium: toward a better understanding of the causes and mechanisms of head and neck cancer. Oral Diseases 2015;21(6):685-93.

\section{Woolgar 2003}

Woolgar JA, Rogers SN, Lowe D, Brown JS, Vaughan ED. Cervical lymph node metastasis in oral cancer: the importance of even microscopic extracapsular spread. Oral Oncology 2003;39(2):130-7.

\section{Worthington 2015}

Worthington $\mathrm{H}$, Clarkson J, Weldon J. Priority oral health research identification for clinical decision-making. Evidencebased Dentistry 2015;16(3):69-71.

\section{Yang 2017}

Yang Y, Zhoug J, Wu H. Diagnostic value of sentinel node biopsy for CT1/T2N0 tongue squamous cell carcinoma: a meta-analysis. European Archives of Oto-rhino-laryngology 2017;274:3843-52.

\section{References to other published versions of this review}

\section{Bessell 2011}

Bessell A, Glenny AM, Furness S, Clarkson JE, Oliver R, Conway DI, et al. Interventions for the treatment of oral and oropharyngeal cancers: surgical treatment. Cochrane Database of Systematic Reviews 2011, Issue 9. [DOI: 10.1002/14651858.CD006205.pub3]

\section{Oliver 2007}

Oliver R, Clarkson JE, Conway D, Glenny AM, Macluskey M, Pavitt $\mathrm{S}$, et al. Interventions for the treatment of oral and oropharyngeal cancers: surgical treatment. Cochrane Database of Systematic Reviews 2007, Issue 4. [DOI: 10.1002/14651858.CD006205.pub2]

* Indicates the major publication for the study

BHNCSG 1998

\begin{tabular}{ll} 
Methods & Location of trial: Brazil \\
& Number of centres: multicentre (8) \\
& Funding: not stated \\
& Trial ID: not stated \\
\hline
\end{tabular}


BHNCSG 1998 (Continued)

Participants
Inclusion criteria: resectable T2 to T4 lesions; clinically negative neck (N0); no prior treatment; histological diagnosis of SCC of the oral tongue, FOM, inferior gingiva or RMT; no need for myocutaneous or free flaps for reconstruction; Karnofsky score $\geq 60$.

Exclusion criteria: significant cardiac or pulmonary diseases, distant metastases or multiple primary cancers (or both).

Recruitment period: May 1990 to December 1993

Number randomised: 148 (all OC: 42\% tongue, 33\% FOM, 8\% inferior gingiva, 17\% RMT)

Number analysed: 148
Interventions

\section{MRND vs SOH}

Group $1(n=76)$ : MRND: surgery conducted centripetally toward the submandibular triangle.

Group 2 ( $n=72$ ): SOH: dissection performed to achieve a compartmental excision of levels I, II and III lymph nodes. Where a positive node was confirmed during the procedure, the operation was converted to an MRND.

For both groups, PORT was indicated in cases with positive margins or positive lymph nodes (or both) in the specimen. RT was over 5 consecutive weeks to deliver a total dose of $50 \mathrm{~Gy}$.

All participants had primary tumour resection.

\begin{tabular}{ll}
\hline Outcomes & Primary: overall survival, recurrence \\
& Secondary: adverse events \\
& Duration of follow-up: 5 years \\
\hline Notes & HR data taken from Kaplan-Meier graph (no numbers at risk).
\end{tabular}

\section{Risk of bias}

\begin{tabular}{lll}
\hline Bias & Authors' judgement & Support for judgement \\
\hline $\begin{array}{ll}\text { Random sequence genera- } \\
\text { tion (selection bias) }\end{array}$ & Unclear risk & $\begin{array}{l}\text { Quote: "Patients were stratified by institution and laterality (unilateral or bilat- } \\
\text { eral) and subsequently randomised." }\end{array}$ \\
& & Method of sequence generation not described.
\end{tabular}

\begin{tabular}{|c|c|c|}
\hline $\begin{array}{l}\text { Allocation concealment } \\
\text { (selection bias) }\end{array}$ & Unclear risk & Insufficient information to determine 'yes' or 'no.' \\
\hline $\begin{array}{l}\text { Blinding of outcome as- } \\
\text { sessment (detection bias) } \\
\text { All outcomes }\end{array}$ & Low risk & Mortality was primary outcome and considered an objective outcome. \\
\hline $\begin{array}{l}\text { Incomplete outcome data } \\
\text { (attrition bias) } \\
\text { All outcomes }\end{array}$ & Low risk & No dropouts \\
\hline $\begin{array}{l}\text { Selective reporting (re- } \\
\text { porting bias) }\end{array}$ & Low risk & No evidence of selective reporting \\
\hline Other bias & Low risk & $\begin{array}{l}\text { Groups appeared similar at baseline. No evidence of other potential sources of } \\
\text { bias. }\end{array}$ \\
\hline
\end{tabular}


Bier 1994

Methods

Location of trial: Germany, Austria and Switzerland

Number of centres: multicentre

Funding: not stated

Trial ID: not stated (part of The German-Austrian-Swiss Association for Head and Neck Tumours (DOSAK))

\section{Participants}

Inclusion criteria: untreated SCC of the oral cavity without metastases, primary tumour on 1 side postcanine or postmolar, i.e. second (postcanine) or third (postmolar) part of the tongue, non-palpable or clinically negative, or clinically positive, movable lymph nodes in the neck.

Exclusion criteria: fixed lymph nodes in the neck.

Recruitment period: uncertain

Number randomised: 167 (all OC: 37\% tongue, 21\% FOM, 16\% RMT, 14\% mandible, $8 \%$ maxilla, 3\% cheek, $1 \%$ other)

Number analysed: 104

\section{Interventions Radical ND vs selective ND}

Group 1 ( $n=48$ ): radical ND (ipsilateral) on the draining lymph nodes. Radical dissection designated as removal of: 1. platysma, sternocleidomastoid muscle, omohyoid muscle, stylohyoid muscle, distal part of the biventer cervicis and fascia colli; 2 . the accessory nerve, descending branch of the hypoglossus nerve and branches of the cervical plexus; 3 . the cervical vein, superficial jugular vein and internal jugular vein; 4. fat tissue, submandibular gland and lower part of the parotid gland.

Group $2(n=56)$ : selective ND (ipsilateral) on the draining lymph nodes. Selective dissection designated as retention of the platysma, sternocleidomastoid muscle, internal jugular vein and the accessory nerve.

All participants underwent radical resection of the primary tumour.

\begin{tabular}{|c|c|c|}
\hline \multirow[t]{3}{*}{ Outcomes } & \multicolumn{2}{|c|}{ Primary: overall survival, recurrence } \\
\hline & \multicolumn{2}{|l|}{ Secondary: metastases } \\
\hline & \multicolumn{2}{|c|}{ Duration of follow-up: 4 years } \\
\hline \multirow[t]{3}{*}{ Notes } & \multicolumn{2}{|l|}{ Preliminary report } \\
\hline & \multicolumn{2}{|c|}{$\begin{array}{l}\text { ND was followed by RT or chemotherapy (or both) in participants not undergoing radical resection of } \\
\text { the primary tumour and in participants with capsular rupture in } \geq 1 \text { lymph node. These participants } \\
\text { were not included in the analysis. }\end{array}$} \\
\hline & \multicolumn{2}{|c|}{ HR data taken from Kaplan-Meier graph (no numbers at risk). } \\
\hline \multicolumn{3}{|l|}{ Risk of bias } \\
\hline Bias & Authors' judgement & Support for judgement \\
\hline \multirow[t]{2}{*}{$\begin{array}{l}\text { Random sequence genera- } \\
\text { tion (selection bias) }\end{array}$} & Unclear risk & $\begin{array}{l}\text { Quote: "Randomized according to the treatment-dependant prognostic index } \\
\text { (TPI) of the DOSAK." }\end{array}$ \\
\hline & & Method of sequence generation not described. \\
\hline
\end{tabular}


Bier 1994 (Continued)

$\begin{aligned} & \text { Allocation concealment } \\ & \text { (selection bias) }\end{aligned}$
Unclear risk Insufficient information to determine 'yes' or 'no.'
(selection bias)

Blinding of outcome as- Low risk sessment (detection bias)

All outcomes

\begin{tabular}{lll}
\hline $\begin{array}{l}\text { Incomplete outcome data } \\
\text { (attrition bias) }\end{array}$ & High risk & $\begin{array}{l}\text { Interim analysis of 104/167 participants randomised published in 1994. No } \\
\text { subsequent publication identified. Participants who did not have radical } \\
\text { surgery at the primary site and participants who had extracapsular rupture of } \\
\geq 1 \text { lymph node were not included in the evaluation. }\end{array}$ \\
\hline $\begin{array}{l}\text { Selective reporting (re- } \\
\text { porting bias) }\end{array}$ & Low risk & No evidence of selective reporting. \\
\hline Other bias & Unclear risk & No information about comparability of groups at baseline. \\
\hline
\end{tabular}

\section{D'Cruz 2015}

\begin{tabular}{ll}
\hline Methods & Location of trial: India \\
& Number of centres: 1 \\
Funding: Tata Memorial Centre \\
Trial ID: NCT00193765 \\
\hline
\end{tabular}

Participants

Inclusion criteria: aged 18-75 years with histopathologically confirmed, invasive SCC of the oral cavity (tongue, FOM or buccal mucosa) that met the staging criteria of the Union for International Cancer Control tumour stage T1 (measuring $\leq 2 \mathrm{~cm}$ ) or T2 (measuring $>2 \mathrm{~cm}$ but $<4 \mathrm{~cm}$ ) that was lateralised to 1 side of the midline. In addition, all participants had received no previous treatment, were amenable to undergoing oral excision, and had no history of head and neck cancer.

Exclusion criteria: previous surgery in the head and neck region, upper alveolar or palatal lesions, large heterogeneous leukoplakias or diffuse oral submucous fibrosis.

Recruitment period: 2004-2014

Number randomised: 596

Number analysed: 496

\section{Elective vs therapeutic ND in node-negative OC}

Group 1 ( $n=298$ ): underwent elective surgery (ipsilateral selective ND with clearance of the submandibular (level I), upper jugular (level II), and midjugular (level III) nodes). Participants with metastatic nodal disease that was discovered during surgery (operative findings or frozen section), had a modified ND performed with nodal clearance extended to include the lower jugular (level IV) and posterior triangle (level V) nodes.

Group 2 ( $n=298$ ): underwent therapeutic surgery (the same surgical procedure for the primary tumour and were then monitored, with modified ND (levels I-V) only at the time of nodal relapse.

All participants underwent oral excision of the primary tumour with adequate margins (i.e. $\geq 5 \mathrm{~mm}$ ).

All participants underwent secondary randomisation for follow-up (to receive either physical examination or physical examination + ultrasonography of the neck). 
D'Cruz 2015 (Continued)

$$
\begin{aligned}
& \text { Secondary: none noted } \\
& \text { Duration of follow-up: median } 39 \text { months }
\end{aligned}
$$

\section{Notes}

\begin{tabular}{|c|c|c|}
\hline Bias & Authors' judgement & Support for judgement \\
\hline $\begin{array}{l}\text { Random sequence genera- } \\
\text { tion (selection bias) }\end{array}$ & Low risk & $\begin{array}{l}\text { Used a computer random number generator (i.e. prepared computerised } \\
\text { block design). }\end{array}$ \\
\hline $\begin{array}{l}\text { Allocation concealment } \\
\text { (selection bias) }\end{array}$ & Unclear risk & Insufficient information to permit judgement of 'low risk' or 'high risk.' \\
\hline $\begin{array}{l}\text { Blinding of outcome as- } \\
\text { sessment (detection bias) } \\
\text { All outcomes }\end{array}$ & Low risk & Survival was primary outcome and considered an objective outcome. \\
\hline $\begin{array}{l}\text { Incomplete outcome data } \\
\text { (attrition bias) } \\
\text { All outcomes }\end{array}$ & Unclear risk & $\begin{array}{l}45 \text { participants excluded from elective surgery group ( } 1 \text { withdrew consent, } 1 \\
\text { had previous chemotherapy, } 43 \text { did not complete 9-month follow-up). } \\
55 \text { participants excluded from therapeutic surgery group ( } 2 \text { had lesion cross- } \\
\text { ing midline, } 53 \text { did not complete 9-month follow-up }\end{array}$ \\
\hline $\begin{array}{l}\text { Selective reporting (re- } \\
\text { porting bias) }\end{array}$ & Low risk & $\begin{array}{l}\text { Study protocol available and all of the study's prespecified (primary and sec- } \\
\text { ondary) outcomes that were of interest in the review were reported as per the } \\
\text { protocol. }\end{array}$ \\
\hline Other bias & Low risk & No other apparent bias \\
\hline
\end{tabular}

\section{Risk of bias}

\section{Fakih 1989}

\begin{tabular}{ll}
\hline Methods & Location of trial: India \\
& Number of centres: 1 \\
& Funding: not stated \\
& Trial ID: not stated \\
\hline Participants & Inclusion criteria: T1 to T2, N0 M0, histologically confirmed SCC of the anterior two-thirds of the oral \\
tongue. & Exclusion criteria: not stated \\
& Recruitment period: July 1985 to September 1988 \\
& Number randomised: 100 (all OC; $100 \%$ tongue) \\
& Number analysed: 70 \\
\hline
\end{tabular}

\section{Elective radical ND vs therapeutic radical ND}

Group $1(n=30)$ : radical ND (ipsilateral)

Group $2(n=40)$ : only participants developing neck node metastasis underwent radical ND 
Fakih 1989 (Continued)

All participants underwent resection of the primary tumour (standard anterior two-thirds hemiglossectomy).

\begin{tabular}{ll}
\hline Outcomes & Primary: overall survival, DFS, disease-related mortality, recurrent disease \\
& Secondary: none noted. \\
& Duration of follow-up: 1 year \\
\hline Notes & No data available for calculation of HR \\
\hline
\end{tabular}

\section{Risk of bias}

\begin{tabular}{|c|c|c|}
\hline Bias & Authors' judgement & Support for judgement \\
\hline $\begin{array}{l}\text { Random sequence genera- } \\
\text { tion (selection bias) }\end{array}$ & Low risk & Quote: "Randomised from previously generated random numbers." \\
\hline $\begin{array}{l}\text { Allocation concealment } \\
\text { (selection bias) }\end{array}$ & Unclear risk & Insufficient information to determine 'yes' or 'no.' \\
\hline $\begin{array}{l}\text { Blinding of outcome as- } \\
\text { sessment (detection bias) } \\
\text { All outcomes }\end{array}$ & Low risk & Survival was primary outcome and considered an objective outcome. \\
\hline $\begin{array}{l}\text { Incomplete outcome data } \\
\text { (attrition bias) } \\
\text { All outcomes }\end{array}$ & High risk & $\begin{array}{l}\text { Interim analysis, no final analysis reported. } 73 \text { participants entered into pro- } \\
\text { tocol, } 12 \text { refused treatment and } 2 \text { were declared unfit for surgery. Of the re- } \\
\text { maining } 59 \text { who completed initial treatment, } 35 \text { who completed a median of } \\
22 \text { months follow-up were included in the analysis (approximately } 48 \% \text { ). }\end{array}$ \\
\hline $\begin{array}{l}\text { Selective reporting (re- } \\
\text { porting bias) }\end{array}$ & Low risk & No evidence of selective outcome reporting. \\
\hline Other bias & Unclear risk & No information about comparability of groups at baseline. \\
\hline
\end{tabular}

Guo 2014

\begin{tabular}{ll}
\hline Methods & Location of trial: China \\
& Number of centres: 1 \\
& Funding: not stated \\
& Trial ID: not stated \\
\hline Participants & no evidence of distant metastasis; no previous treatment \\
& Exclusion criteria: not stated \\
& Recruitment period: June 1999 to May 2010 \\
& Number randomised: 332 \\
& Number analysed: 322 \\
\hline
\end{tabular}


Guo 2014 (Continued)

Group $1(n=166)$ : allocated to SOH ND arm (received surgery alone $(n=109)$, received surgery + PORT $(n=57))$

Group $2(n=166)$ : allocated to MRND arm (received surgery alone $(n=114)$, received surgery + PORT ( $n$ =52))

\begin{tabular}{ll}
\hline Outcomes & Primary: DSS, NCR \\
& Secondary: quality of life (QoL) assessments \\
& Duration of follow-up: median 76 months (1 year for QoL) \\
\hline Notes & $\begin{array}{l}\text { NCR defined as proportion of participants who did not develop postoperative nodal metastases within } \\
\text { 3 years. }\end{array}$
\end{tabular}

\begin{tabular}{|c|c|c|}
\hline \multicolumn{3}{|l|}{ Risk of bias } \\
\hline Bias & Authors' judgement & Support for judgement \\
\hline $\begin{array}{l}\text { Random sequence genera- } \\
\text { tion (selection bias) }\end{array}$ & Unclear risk & $\begin{array}{l}\text { Insufficient information about the sequence generation process to permit } \\
\text { judgement of 'low risk' or 'high risk.' }\end{array}$ \\
\hline $\begin{array}{l}\text { Allocation concealment } \\
\text { (selection bias) }\end{array}$ & Unclear risk & Insufficient information to permit judgement of 'low risk' or 'high risk.' \\
\hline $\begin{array}{l}\text { Blinding of outcome as- } \\
\text { sessment (detection bias) } \\
\text { All outcomes }\end{array}$ & Low risk & Mortality was primary outcome and considered an objective outcome. \\
\hline $\begin{array}{l}\text { Incomplete outcome data } \\
\text { (attrition bias) } \\
\text { All outcomes }\end{array}$ & Low risk & $\begin{array}{l}10(3 \%) \text { participants lost to follow-up soon after randomisation were unable to } \\
\text { be included in the analysis ( } 4 \text { in SOH ND treatment arm, } 6 \text { in MRND treatment } \\
\text { arm). }\end{array}$ \\
\hline $\begin{array}{l}\text { Selective reporting (re- } \\
\text { porting bias) }\end{array}$ & Low risk & No evidence of selective outcome reporting. \\
\hline Other bias & Low risk & No other apparent bias. \\
\hline
\end{tabular}

lyer 2015

Methods

Location of trial: Singapore

Number of centres: not stated

Funding: not stated

Trial ID: not stated

\section{Participants}

Inclusion criteria: people newly diagnosed with histologically confirmed, resectable, non-metastatic stage III/IV HNSCC who had a good Eastern Cooperative Oncology Group performance status (0 or 1 ) and adequate bone marrow, hepatic and renal function.

Exclusion criteria: nasopharynx and salivary glands

Recruitment period: August 1996 to February 2002

Number randomised: 119 
Iyer 2015 (Continued)

Number analysed: 118

Surgery and adjuvant RT vs concurrent CRT
Group $1(\mathrm{n}=60)$ : radical surgery + adjuvant RT
Group $2(\mathrm{n}=59)$ : combination chemotherapy with cisplatin and 5-fluorouracil and concurrent RT
Randomisation was stratified according to primary tumour site (oral cavity/oropharynx, larynx/hy-
popharynx, others) and lymph node status (lymph-node positive vs lymph-node negative).

Outcomes To determine whether concurrent chemotherapy was superior to the prevailing conventional treatment at that time, namely surgery and adjuvant RT, with survival as the endpoint.

Primary: overall survival, DSS, locoregional recurrence-free survival, distant recurrence-free survival

Secondary: none noted

Duration of follow-up for all participants: 10 years

\section{Notes}

\section{Risk of bias}

\begin{tabular}{lll}
\hline Bias & Authors' judgement & Support for judgement \\
\hline $\begin{array}{l}\text { Random sequence genera- } \\
\text { tion (selection bias) }\end{array}$ & Unclear risk & Method of sequence generation not described. \\
\hline $\begin{array}{l}\text { Allocation concealment } \\
\text { (selection bias) }\end{array}$ & Unclear risk & Not mentioned \\
\hline $\begin{array}{l}\text { Blinding of outcome as- } \\
\text { sessment (detection bias) } \\
\text { All outcomes }\end{array}$ & Low risk & Survival was primary outcome and considered an objective outcome. \\
\hline $\begin{array}{l}\text { Incomplete outcome data } \\
\text { (attrition bias) }\end{array}$ & Low risk & \\
$\begin{array}{l}\text { All outcomes } \\
\text { Selective reporting (re- } \\
\text { porting bias) }\end{array}$ & Low risk & $\begin{array}{l}\text { Only 1 participant missing from analysis as histopathological assessment con- } \\
\text { firmed adenocarcinoma, therefore excluded. }\end{array}$ \\
\hline \begin{tabular}{l} 
Other bias \\
\hline
\end{tabular} & Low risk & No evidence of selective outcome reporting. \\
\hline
\end{tabular}

\section{Kligerman 1994}

\begin{tabular}{ll} 
Methods & Location of trial: Brazil \\
& Number of centres: 1 \\
& Funding: government (personal communication) \\
& Trial ID: not stated \\
\hline
\end{tabular}

Participants

Inclusion criteria: resectable early stage (T1 to T2, N0) SCC of tongue and FOM

Exclusion criteria: not stated 
Kligerman 1994 (Continued)

Recruitment period: 1987-1992

Number randomised: 67 (all OC: 61\% tongue, 39\% FOM)

Number analysed: 67

\section{Elective ND vs therapeutic ND}

Group $1(n=34)$ : elective SOH ND. Dissection of levels $1-3$ + resection of submandibular gland, preserving the sternocleidomastoid muscle, spinal accessory nerve and internal jugular vein

Group $2(n=33)$ : therapeutic ND

All participants underwent resection of the primary tumour.

Primary: overall survival, DFS, locoregional recurrence, disease-related mortality
Secondary: none noted
Duration of follow-up: 3.5 years

\begin{tabular}{|c|c|}
\hline \multirow[t]{2}{*}{ Notes } & $\begin{array}{l}\text { Paper reported that overall survival assessed by Kaplan-Meier actuarial method, but not presented. } \\
\text { HR data taken from Kaplan-Meier graph (no numbers at risk) for DFS. }\end{array}$ \\
\hline & Locoregional failure data unclear. \\
\hline
\end{tabular}

\section{Risk of bias}

\begin{tabular}{lll}
\hline Bias & Authors' judgement & Support for judgement \\
\hline $\begin{array}{l}\text { Random sequence genera- } \\
\text { tion (selection bias) }\end{array}$ & Unclear risk & $\begin{array}{l}\text { Quote: "All 67 patients were stratified by stage...and those in each stage were } \\
\text { randomised." } \\
\text { Method of sequence generation not described. }\end{array}$ \\
\hline $\begin{array}{l}\text { Allocation concealment } \\
\text { (selection bias) }\end{array}$ & Unclear risk & Insufficient information to determine 'yes' or 'no.' \\
\hline $\begin{array}{l}\text { Blinding of outcome as- } \\
\text { sessment (detection bias) }\end{array}$ & Low risk & Mortality was primary outcome and considered an objective outcome. \\
\hline $\begin{array}{l}\text { All outcomes } \\
\text { Incomplete outcome data }\end{array}$ & Low risk & No dropouts \\
$\begin{array}{l}\text { All outcomes } \\
\text { Selective reporting (re- } \\
\text { porting bias) }\end{array}$ & Low risk & No evidence of selective outcome reporting \\
\hline \begin{tabular}{l} 
Other bias \\
\hline
\end{tabular} & Unclear risk & No information about comparability of groups at baseline \\
\hline
\end{tabular}

Mehanna 2017

\begin{tabular}{ll}
\hline Methods & Location of trial: UK \\
& Number of centres: 38
\end{tabular}


Funding: Health Technology programme of National Institute for Health Research Technology Assessment Programme and Cancer Research UK

Trial ID: ISRCTN13735240

Participants
Inclusion criteria (must have met all):

- histological diagnosis of oropharyngeal, laryngeal, oral, hypopharyngeal or occult HNSCC;

- clinical and CT/MRI imaging evidence of nodal metastases staged N2 (a, b or c) or N3;

- indication to receive curative radical concurrent CRT for primary;

- fitness for ND surgery;

- ND was technically feasible to perform and remove nodal disease (e.g. no carotid encasement, no direct extension between tumour and nodal disease);

- aged $\geq 18$ years;

- able to give informed consent;

- receiving 1 of the CRT regimens approved by the study.

Exclusion criteria (any criteria met ruled patients ineligible):

- undergoing resection for primary tumour (diagnostic tonsillectomy was not considered an exclusion criteria);

- distant metastases to chest, liver, bones or other sites;

- previous treatment for HNSCC;

- pregnant;

- another cancer diagnosis in the past 5 years (except basal cell carcinoma or carcinoma of the cervix in situ).

Recruitment period: 2 October 2007 to 23 August 2012

Number randomised: 564 (84.4\% OP cancer)

Number analysed: 564 (personal communication)

\section{PET-CT surveillance (following CRT) vs planned ND (either before or after CRT) in advanced head and neck cancer}

Assessed the non-inferiority of PET-CT-guided surveillance (performed 12 weeks after the end of CRT, with ND performed only if PET-CT showed an incomplete or equivocal response) to planned ND (either before or after (RT) in people with stage N2 or N3 disease.

Group 1 ( $n=282)$ : PET-CT 12 weeks after completion of CRT (surveillance group)

Group 2 ( $n=282)$ : planned ND (either before or after CRT)

Primary: overall survival

Secondary: quality of life, surgical complications

Follow-up period: 36 months (median)

Notes

Before randomisation, each participating centre had to specify on a per-participant basis whether planned ND would be performed within 4 weeks before or within 4-8 weeks after completion of CRT. In addition, before randomisation, clinicians selected CRT regimens from a list of the approved study regimens.

Intention-to-treat analysis was carried out for all 564 participants. Kaplan-Meier analysis was used to estimate survival rate due to the loss of some participants.

\section{Risk of bias}


Mehanna 2017 (Continued)

\begin{tabular}{|c|c|c|}
\hline Bias & Authors' judgement & Support for judgement \\
\hline $\begin{array}{l}\text { Random sequence genera- } \\
\text { tion (selection bias) }\end{array}$ & Low risk & Minimisation algorithm used; table 1 listed variables for comparison. \\
\hline $\begin{array}{l}\text { Allocation concealment } \\
\text { (selection bias) }\end{array}$ & Unclear risk & Unclear how allocation concealment occurred. \\
\hline $\begin{array}{l}\text { Blinding of outcome as- } \\
\text { sessment (detection bias) } \\
\text { All outcomes }\end{array}$ & Low risk & Survival was primary outcome and considered an objective outcome. \\
\hline $\begin{array}{l}\text { Incomplete outcome data } \\
\text { (attrition bias) } \\
\text { All outcomes }\end{array}$ & Low risk & All participants assessed as part of the intention-to-treat analysis. \\
\hline $\begin{array}{l}\text { Selective reporting (re- } \\
\text { porting bias) }\end{array}$ & Low risk & $\begin{array}{l}\text { Study protocol was published and outcomes were published according to pro- } \\
\text { tocol. }\end{array}$ \\
\hline Other bias & Low risk & No other potential sources of bias identified. \\
\hline
\end{tabular}

\section{Rastogi 2018}

\begin{tabular}{ll}
\hline Methods & Location of trial: India \\
& Number of centres: 1 \\
& Funding: not stated \\
Trial ID: not stated
\end{tabular}

Participants Inclusion criteria: aged > 18 years, established diagnosis of SCC as defined by the AJCC classification,
T1-T3 lesions of the oral cavity with NO neck.

Exclusion criteria: requiring radical ND or modified radical ND; history of surgery or RT of the head and neck region; history of shoulder pain, dysfunction or weakness including myopathy, neuropathy or arthropathy; any type of implanted electrical device prior to surgery; previous or current neurological illness; did not provide written informed consent; unwilling to attend follow-up appointments.

Recruitment period: August 2014 to March 2017

Number randomised: 20

Number analysed: 20

\section{Selective ND vs super-selective ND for people with oral carcinoma and NO neck in terms of shoul-} der morbidity and recurrence rate

Group $1(n=10)$ : selective ND of levels I, Ila, IIb and III

Group $2(n=10)$ : super selective ND of levels I, Ila and III

Outcomes Primary: rate of recurrence over 2.5 years

Secondary: Arm Abduction Test, quality of life assessed by subjective questionnaire (Neck Dissection Quality of Life Questionnaire)

Duration of follow-up period for all participants: 2.5 years 
Rastogi 2018 (Continued)

Notes Small sample size

\section{Risk of bias}

\begin{tabular}{|c|c|c|}
\hline Bias & Authors' judgement & Support for judgement \\
\hline $\begin{array}{l}\text { Random sequence genera- } \\
\text { tion (selection bias) }\end{array}$ & Unclear risk & Unclear how the randomisation occurred using the "slot method." \\
\hline $\begin{array}{l}\text { Allocation concealment } \\
\text { (selection bias) }\end{array}$ & Unclear risk & Unclear if the investigators utilised appropriate allocation concealment. \\
\hline $\begin{array}{l}\text { Blinding of outcome as- } \\
\text { sessment (detection bias) } \\
\text { All outcomes }\end{array}$ & Low risk & Mortality was primary outcome and considered an objective outcome. \\
\hline $\begin{array}{l}\text { Incomplete outcome data } \\
\text { (attrition bias) } \\
\text { All outcomes }\end{array}$ & Low risk & All participants completed the trial with analysis undertaken for all. \\
\hline $\begin{array}{l}\text { Selective reporting (re- } \\
\text { porting bias) }\end{array}$ & Low risk & $\begin{array}{l}\text { Outcomes clearly stated in methods section and appropriately measured in re- } \\
\text { sults section. }\end{array}$ \\
\hline Other bias & Low risk & No other sources of bias noted. \\
\hline
\end{tabular}

\section{Robertson 1998}

\begin{tabular}{ll}
\hline Methods & Location of trial: UK \\
& Number of centres: multicentre (4) \\
& Funding: not stated \\
& Trial ID: not stated \\
\hline
\end{tabular}

\section{Participants}

Inclusion criteria: resectable, stage T2-T4, N0-N2, M0 head and neck tumours

Exclusion criteria: stage I (T1NOM0); history of malignancy, apart from basal cell carcinoma of the skin, or intraepithelial carcinoma of the cervix

Recruitment period: December 1991 to December 1993

Number randomised: 35 (intended 350 but trial stopped early due to concern of the number of deaths in the RT alone arm) (33/35 OC: 40\% tongue, 43\% FOM, 11\% RMT, 6\% tonsil)

Number analysed: 35

Interventions

\section{Surgery + RT vs RT alone}

Group $1(n=17)$ : radical resection and ND + PORT. Radical surgery involved wide local excision of the primary tumour with $1 \mathrm{~cm}$ margin. A radical or functional ND was carried out at the same time at the discretion of the surgeon. Reconstruction of the oral cavity was carried out immediately. PORT comprised 60 Gy in 30 fractions over 6 weeks, commencing within 6-8 weeks of surgery.

Group 2 ( $n=18)$ : RT alone; 66 Gy in 33 fractions over 6.5 weeks, receiving 2 Gy per day 
Robertson 1998 (Continued)

Secondary: adverse events

Duration of follow-up: 3 years

Hotes
HR data taken from Kaplan-Meier graph (no numbers at risk).
Data presented in Kaplan-Meier estimates for DFS, but not used as graph started at 50\% for RT alone
arm.
Authors provided additional information relating to allocation concealment and the characteristics of
tumours.

\section{Risk of bias}

\begin{tabular}{|c|c|c|}
\hline Bias & Authors' judgement & Support for judgement \\
\hline $\begin{array}{l}\text { Random sequence genera- } \\
\text { tion (selection bias) }\end{array}$ & Low risk & $\begin{array}{l}\text { Quote: "Random permuted blocks of four were used for randomization" fol- } \\
\text { lowing stratification according to institution and site of primary disease. }\end{array}$ \\
\hline $\begin{array}{l}\text { Allocation concealment } \\
\text { (selection bias) }\end{array}$ & Low risk & $\begin{array}{l}\text { Randomisation via a telephone call to the West of Scotland Clinical Trials Of- } \\
\text { fice. }\end{array}$ \\
\hline $\begin{array}{l}\text { Blinding of outcome as- } \\
\text { sessment (detection bias) } \\
\text { All outcomes }\end{array}$ & Low risk & Mortality was primary outcome and considered an objective outcome. \\
\hline $\begin{array}{l}\text { Incomplete outcome data } \\
\text { (attrition bias) } \\
\text { All outcomes }\end{array}$ & Low risk & No dropouts \\
\hline $\begin{array}{l}\text { Selective reporting (re- } \\
\text { porting bias) }\end{array}$ & Low risk & No evidence of selective reporting of outcomes. \\
\hline Other bias & High risk & $\begin{array}{l}\text { Anticipated enrolment of } 350 \text { participants, but trial stopped after } 35 \text { partici- } \\
\text { pants recruited because clinicians felt it was unethical to continue. Appropri- } \\
\text { ate procedures and analysis were conducted. More than half of participants re- } \\
\text { cruited had either delays or interruptions to the planned RT schedule. It is like- } \\
\text { ly that this would have had a greater effect on the outcomes of the RT alone } \\
\text { arm of this trial. }\end{array}$ \\
\hline
\end{tabular}

Vandenbrouck 1980

\begin{tabular}{ll}
\hline Methods & Location of trial: France \\
& Number of centres: 1 \\
& Funding: not stated \\
& Trial ID: not stated \\
\hline Participants & Inclusion criteria: T1-T3, N0, SCC oral cavity, tongue or lower FOM; any age or sex with no previous \\
& node/s no larger than $1 \mathrm{~cm}$. \\
& Exclusion criteria: not stated \\
& Recruitment period: $1966-1973$ \\
& Numbers random infusion; neck free of disease or willary \\
\end{tabular}


Vandenbrouck 1980 (Continued)

Numbers analysed: 75

\section{Interventions $\quad$ Elective radical ND vs therapeutic radical ND}

Group $1(n=39)$ : elective ND within 2 months of treatment of primary lesion. In cases of lateral tumour, an ipsilateral radical ND with removal of sternocleidomastoid muscle, internal jugular vein without sparing the spinal accessory nerve was performed. When tumour crossed or close to midline submental, submaxillary and jugulodigastric contralateral dissection performed. Nodal involvement resulted in PORT.

Group 2 ( $n=36$ ): therapeutic (delayed) dissection. These participants were followed for $\geq 3$ years and underwent ND if a cervical node became enlarged.

All participants received interstitial RT to the primary tumour site prior to randomisation.

Primary: overall survival, DFS, disease-related mortality, recurrent disease
Secondary: none noted
Duration of follow-up period: 5 years

\section{Notes}

\section{Risk of bias}

\begin{tabular}{|c|c|c|}
\hline Bias & Authors' judgement & Support for judgement \\
\hline \multirow[t]{2}{*}{$\begin{array}{l}\text { Random sequence genera- } \\
\text { tion (selection bias) }\end{array}$} & Unclear risk & $\begin{array}{l}\text { Quote: "Randomisation was under the control of a statistician who observed } \\
\text { the strictest protocol." }\end{array}$ \\
\hline & & However, method of sequence generation was not described. \\
\hline \multirow[t]{2}{*}{$\begin{array}{l}\text { Allocation concealment } \\
\text { (selection bias) }\end{array}$} & Low risk & $\begin{array}{l}\text { Quote: "Randomisation was under the control of a statistician who observed } \\
\text { the strictest protocol." }\end{array}$ \\
\hline & & Assumed this was adequate. \\
\hline $\begin{array}{l}\text { Blinding of outcome as- } \\
\text { sessment (detection bias) } \\
\text { All outcomes }\end{array}$ & Low risk & Survival was primary outcome and considered an objective outcome. \\
\hline $\begin{array}{l}\text { Incomplete outcome data } \\
\text { (attrition bias) } \\
\text { All outcomes }\end{array}$ & Low risk & No dropouts \\
\hline $\begin{array}{l}\text { Selective reporting (re- } \\
\text { porting bias) }\end{array}$ & Low risk & No evidence of selective outcome reporting. \\
\hline Other bias & Low risk & No evidence of other potential sources of bias. \\
\hline
\end{tabular}

Yuen 2009

Location of trial: Hong Kong, China
Number of centres: 3
Funding: not stated


Yuen 2009 (Continued)

Trial ID: not stated

Participants Inclusion criteria: AJCC, Stage I to II, SCC oral tongue; no nodal metastases; no prior surgery, chemotherapy or RT

Exclusion criteria: OC of other subsites, or cancer of base of tongue

Recruitment period: $1996-2004$

Numbers randomised: 72 (all OC: 100\% tongue)

Numbers analysed: 71

\section{Interventions Elective selective ND vs therapeutic radical ND}

Group 1 ( $n=36)$ : elective ipsilateral selective ND of level I, II or III neck nodes.

Group 2 ( $n=36$ ): therapeutic (delayed) dissection. These participants were followed, and received ultrasound examinations every 3 months for the first 3 years. If nodal recurrence was detected, these participants underwent either radical or modified radical ND followed by RT.

All participants in the trial had transoral glossectomy with 1.5 resection margins.

Outcomes

Primary: nodal recurrence, disease recurrence, death due to tumour, 5-year tumour-specific survival

Duration of follow-up: $34-122$ months

Notes

\section{Risk of bias}

\begin{tabular}{lll}
\hline Bias & Authors' judgement & Support for judgement \\
\hline $\begin{array}{l}\text { Random sequence genera- } \\
\text { tion (selection bias) }\end{array}$ & Unclear risk & $\begin{array}{l}\text { Randomisation stratified by tumour stage. Method of sequence generation not } \\
\text { described. }\end{array}$ \\
\hline $\begin{array}{l}\text { Allocation concealment } \\
\text { (selection bias) }\end{array}$ & Unclear risk & $\begin{array}{l}\text { Used sealed envelopes to contain the allocation. Insufficient information to } \\
\text { determine whether allocation was concealed from investigators. }\end{array}$ \\
\hline $\begin{array}{l}\text { Blinding of outcome as- } \\
\text { sessment (detection bias) } \\
\text { All outcomes }\end{array}$ & Low risk & Mortality was primary outcome and considered an objective outcome. \\
\hline $\begin{array}{l}\text { Incomplete outcome data } \\
\text { (attrition bias) } \\
\text { All outcomes }\end{array}$ & Low risk & $\begin{array}{l}\text { 1 participant allocated to observation group was subsequently found to have } \\
\text { T3 tumour and was withdrawn. All other randomised participants included in } \\
\text { the outcome evaluations. }\end{array}$ \\
\hline $\begin{array}{l}\text { Selective reporting (re- } \\
\text { porting bias) }\end{array}$ & High risk & $\begin{array}{l}\text { Reported nodal and local recurrence, DFS and disease-specific death. No re- } \\
\text { porting of mortality in each group. }\end{array}$ \\
\hline \begin{tabular}{l} 
Other bias \\
\hline
\end{tabular} & Low risk & \begin{tabular}{l} 
Groups appeared similar at baseline. \\
\hline
\end{tabular}
\end{tabular}

AJCC: American Joint Committee on Cancer; CRT: chemoradiotherapy; CT: computer tomography; DFS: disease-free survival; DSS: diseasespecific survival; FOM: floor of mouth; HNSCC: head and neck squamous-cell carcinoma; HR: hazard ratio; MRI: magnetic resonance imaging; MRND: modified radical classical neck dissection; n: number of participants; NCR: neck control rate; ND: neck dissection; OC: oral cancer; OP: oropharyngeal cancer; PET-CT: positron-emission tomography-computed tomography; PORT: postoperative radiotherapy; RMT: retromolar trigone; RT: radiotherapy; SCC: squamous-cell carcinoma; SE: standard error; SOH: supraomohyoid neck dissection. 
Characteristics of excluded studies [ordered by study ID]

\begin{tabular}{|c|c|}
\hline Study & Reason for exclusion \\
\hline Abbade 2015 & Study was about basal cell carcinoma, which is not related to oral cavity cancer. \\
\hline Ajmani 2017 & Not an RCT \\
\hline Ang 2001 & $\begin{array}{l}\text { RCT now included in review 'Interventions for the treatment of oral cavity and oropharyngeal can- } \\
\text { cer: radiotherapy' (Glenny 2010). }\end{array}$ \\
\hline Batra 2016 & Short-term outcomes only (wound closure). \\
\hline Bernier 2004 & $\begin{array}{l}\text { RCT now included in review 'Interventions for the treatment of oral cavity and oropharyngeal can- } \\
\text { cer: chemotherapy' (Furness 2011). }\end{array}$ \\
\hline Bier 1981 & $\begin{array}{l}\text { RCT to be included in review 'Interventions for the treatment of oral cavity and oropharyngeal can- } \\
\text { cer: immunotherapy.' }\end{array}$ \\
\hline Cooper 2004 & $\begin{array}{l}\text { RCT now included in review 'Interventions for the treatment of oral cavity and oropharyngeal can- } \\
\text { cer: chemotherapy' (Furness 2011). }\end{array}$ \\
\hline De Stefani 2002 & $\begin{array}{l}\text { RCT to be included in review 'Interventions for the treatment of oral cavity and oropharyngeal can- } \\
\text { cer: immunotherapy.' }\end{array}$ \\
\hline Dean 2013 & $\begin{array}{l}\text { Short-term outcomes only (e.g. operative time, reduces blood loss during surgery, time drains are } \\
\text { kept in place, amount of drainage). }\end{array}$ \\
\hline Fan 2017 & Short-term outcomes only (e.g. postoperative immune response and surgical stress). \\
\hline Fritz 2016 & Short-term outcomes only (e.g. blood loss and operating time). \\
\hline Funahara 2017 & Short-term outcomes only (e.g. surgical wound infections). \\
\hline George 2014 & Not an RCT \\
\hline Gundale 2017 & Abstract, insufficient information \\
\hline Hintz 1979a & Head and neck cancer study with $<50 \%$ oral cancer/oropharyngeal cancer. \\
\hline Hintz 1979b & Head and neck cancer study with < 50\% oral cancer/oropharyngeal cancer. \\
\hline Howard 2016 & Systematic review \\
\hline Jinyun 2015 & Not an RCT \\
\hline Kramer 1987 & $\begin{array}{l}\text { Insufficient detail in published report to establish what the surgical procedures involved and } \\
\text { whether these were the same in all groups. Insufficient information to enable either risk of bias as- } \\
\text { sessment to be undertaken. }\end{array}$ \\
\hline Lam 2001 & $\begin{array}{l}\text { RCT now included in review 'Interventions for the treatment of oral cavity and oropharyngeal can- } \\
\text { cer: chemotherapy' (Furness 2011). }\end{array}$ \\
\hline Laramore 1992 & $\begin{array}{l}\text { RCT now included in review 'Interventions for the treatment of oral cavity and oropharyngeal can- } \\
\text { cer: chemotherapy' (Furness 2011). }\end{array}$ \\
\hline
\end{tabular}




\begin{tabular}{|c|c|}
\hline Study & Reason for exclusion \\
\hline Lawrence 1974 & $\begin{array}{l}\text { RCT now included in review 'Interventions for the treatment of oral cavity and oropharyngeal can- } \\
\text { cer: radiotherapy' (Glenny 2010). }\end{array}$ \\
\hline Licitra 2001 & $\begin{array}{l}\text { RCT now included in review 'Interventions for the treatment of oral cavity and oropharyngeal can- } \\
\text { cer: chemotherapy' (Furness 2011). }\end{array}$ \\
\hline Lin 2016 & Short-term study only looking at immediate postsurgical outcomes. \\
\hline Luboinski 1985 & $\begin{array}{l}\text { RCT now included in review 'Interventions for the treatment of oral cavity and oropharyngeal can- } \\
\text { cer: chemotherapy' (Furness 2011). }\end{array}$ \\
\hline Maipang 1995 & $\begin{array}{l}\text { RCT now included in review 'Interventions for the treatment of oral cavity and oropharyngeal can- } \\
\text { cer: chemotherapy' (Furness 2011). }\end{array}$ \\
\hline McCaul 2012 & Abstract, insufficient information \\
\hline McCaul 2017 & Abstract, insufficient information \\
\hline Minkovich 2011 & Short-term outcomes only (e.g. malpositions of peripherally inserted central venous catheters). \\
\hline Mohr 1994 & $\begin{array}{l}\text { RCT now included in review 'Interventions for the treatment of oral cavity and oropharyngeal can- } \\
\text { cer: chemotherapy' (Furness 2011). }\end{array}$ \\
\hline
\end{tabular}

Neifeld 1985 RCT to be included in review 'Interventions for the treatment of oral cavity and oropharyngeal can-
cer: immunotherapy.'

\begin{tabular}{|c|c|}
\hline Oswal 2017 & Short-term outcomes only (e.g. wound closure). \\
\hline Paccagnella 1994 & $\begin{array}{l}\text { RCT now included in review 'Interventions for the treatment of oral cavity and oropharyngeal can- } \\
\text { cer: chemotherapy' (Furness 2011). }\end{array}$ \\
\hline Poh 2011 & 6 months post-treatment; short-term follow-up only. \\
\hline Rao 1991 & $\begin{array}{l}\text { RCT now included in review 'Interventions for the treatment of oral cavity and oropharyngeal can- } \\
\text { cer: chemotherapy' (Furness 2011). }\end{array}$ \\
\hline Rentschler 1987 & $\begin{array}{l}\text { RCT now included in review 'Interventions for the treatment of oral cavity and oropharyngeal can- } \\
\text { cer: chemotherapy' (Furness 2011). }\end{array}$ \\
\hline Richard 1991 & $\begin{array}{l}\text { RCT now included in review 'Interventions for the treatment of oral cavity and oropharyngeal can- } \\
\text { cer: chemotherapy' (Furness 2011). }\end{array}$ \\
\hline Sanguineti 2005 & $\begin{array}{l}\text { RCT now included in review 'Interventions for the treatment of oral cavity and oropharyngeal can- } \\
\text { cer: radiotherapy.' }\end{array}$ \\
\hline Schuller 1988 & $\begin{array}{l}\text { RCT now included in review 'Interventions for the treatment of oral cavity and oropharyngeal can- } \\
\text { cer: chemotherapy' (Furness 2011). }\end{array}$ \\
\hline Szabo 1999 & $\begin{array}{l}\text { RCT now included in review 'Interventions for the treatment of oral cavity and oropharyngeal can- } \\
\text { cer: chemotherapy' (Furness 2011). }\end{array}$ \\
\hline Szpirglas 1978 & $\begin{array}{l}\text { RCT now included in review 'Interventions for the treatment of oral cavity and oropharyngeal can- } \\
\text { cer: chemotherapy' (Furness 2011). }\end{array}$ \\
\hline Terz 1981 & $\begin{array}{l}\text { RCT now included in review 'Interventions for the treatment of oral cavity and oropharyngeal can- } \\
\text { cer: radiotherapy.' }\end{array}$ \\
\hline
\end{tabular}




\begin{tabular}{ll}
\hline Study & Reason for exclusion \\
\hline Tingting 2016 & Not different surgical term \\
\hline Uppal 2012 & Unable to access the original article. \\
\hline Verma 2017 & Short-term study only looking at immediate postsurgical outcomes. \\
\hline Volling 1999 & $\begin{array}{l}\text { RCT now included in review 'Interventions for the treatment of oral cavity and oropharyngeal can- } \\
\text { cer: chemotherapy' (Furness 2011). }\end{array}$ \\
\hline Walen 2011 & Short-term study on postoperative pain. \\
\hline Weissler 1992 & $\begin{array}{l}\text { RCT now included in review 'Interventions for the treatment of oral cavity and oropharyngeal can- } \\
\text { cer: chemotherapy' (Furness 2011). }\end{array}$ \\
\hline Zhang 2010 & Abstract, insufficient information \\
\hline Zhong 2013 & Surgery was not the comparison, mainly chemotherapy. \\
\hline Zhong 2015 & Surgery was not the comparison, mainly chemotherapy \\
\hline
\end{tabular}

$\mathrm{RCT}$ : randomised controlled trial.

Characteristics of ongoing studies [ordered by study ID]

\section{NCT00571883 (SEND)}

\begin{tabular}{ll}
\hline Trial name or title & Neck surgery in treating patients with early-stage oral cancer (SEND trial) \\
\hline Methods & RCT \\
\hline Participants & $\begin{array}{l}\text { People with oral squamous-cell carcinoma 1-3 cm at primary site, no clinical or preoperative imag- } \\
\text { ing evidence of neck involvement (NO) }\end{array}$ \\
\hline Interventions & Selective elective neck dissection + resection of primary tumour vs resection of primary alone \\
\hline Outcomes & $\begin{array}{l}\text { Overall survival, disease-free survival, local and regional recurrence, completeness of primary re- } \\
\text { section, QoL, psychological wellbeing, costs }\end{array}$ \\
\hline Starting date & January 2007 \\
\hline Contact information & Study chair: lain Hutchison, Facial Surgery Research Foundation, UK (send@savingfaces.info) \\
\hline Notes & Currently recruiting July 2009 \\
\hline
\end{tabular}

\section{NCT01334320}

\begin{tabular}{ll}
\hline Trial name or title & Survival benefit of elective neck dissection in T1, 2 N0 M0 oral squamous cell carcinoma \\
\hline Methods & RCT \\
\hline Participants & $\begin{array}{l}\text { Histologically confirmed T1 or T2 N0 M0 (clinical) squamous-cell carcinoma of oral tongue, buccal } \\
\text { mucosa, gingiva, floor of mouth or hard palate }\end{array}$ \\
\hline
\end{tabular}




\section{NCT01334320 (Continued)}

Interventions
Elective superior omohyoid neck dissection vs watch and wait (resection of primary tumour and therapeutic dissection of neck when clinical evidence of disease)

Outcomes Overall and disease-free survival at 5 years, recurrence, QoL

\begin{tabular}{ll}
\hline Starting date & April 2011 \\
\hline Contact information & $\begin{array}{l}\text { Dr Guiqing Lao, Hospital of Stomatology, Sun Yat-sen University, Guangdong, China (drliaogu- } \\
\text { iqing@hotmail.com) }\end{array}$ \\
\hline Notes & Planned enrolment 448 participants \\
\hline
\end{tabular}

\section{Nichols 2013 (formerly NCT01590355)}

\begin{tabular}{|c|c|}
\hline Trial name or title & $\begin{array}{l}\text { Early-stage squamous cell carcinoma of the Oropharynx: Radiotherapy vs. Trans-Oral Robotic } \\
\text { Surgery (ORATOR) - study protocol for a randomized phase II trial }\end{array}$ \\
\hline Participants & $\begin{array}{l}\text { People with oropharyngeal squamous-cell carcinoma who would be unlikely to require chemother- } \\
\text { apy postresection, people with N0 disease will receive radiotherapy alone, whereas people with } \\
\text { N1-2 disease will receive concurrent chemoradiotherapy. }\end{array}$ \\
\hline Interventions & $\begin{array}{l}\text { Participants will undergo transoral robotic surgery along with selective neck dissections, which } \\
\text { may be staged. }\end{array}$ \\
\hline Outcomes & $\begin{array}{l}\text { Primary endpoint QoL score using M.D. Anderson Dysphagia Inventory, with secondary endpoints } \\
\text { including survival, toxicity, other QoL outcomes and swallowing function. }\end{array}$ \\
\hline Starting date & 2013 \\
\hline \multirow[t]{2}{*}{ Contact information } & david.palma@lhsc.on.ca \\
\hline & $\begin{array}{l}\text { Department of Otolaryngology-Head and Neck Surgery, London Health Sciences Centre and West- } \\
\text { ern University, London, ON, Canada }\end{array}$ \\
\hline Notes & Sample of 68 participants is required. \\
\hline
\end{tabular}

QoL: quality of life; RCT: randomised controlled trial.

\section{DATA AND ANALYSES}

\section{Comparison 1. Elective neck dissection (ND) versus therapeutic (delayed) neck dissection}

\begin{tabular}{llllll}
\hline Outcome or subgroup title & $\begin{array}{l}\text { No. of } \\
\text { studies }\end{array}$ & $\begin{array}{l}\text { No. of } \\
\text { partici- } \\
\text { pants }\end{array}$ & Statistical method & Effect size \\
\hline 1 Total mortality (HR for overall survival) & 2 & Hazard Ratio (Random, 95\% Cl) & Subtotals only \\
\hline $\begin{array}{l}1.1 \text { Elective radical neck dissection vs therapeutic } \\
\text { radical neck }\end{array}$ & 2 & Hazard Ratio (Random, 95\% Cl) & $0.84[0.41,1.72]$ \\
\hline \hline
\end{tabular}




\begin{tabular}{|c|c|c|c|c|}
\hline Outcome or subgroup title & $\begin{array}{l}\text { No. of } \\
\text { studies }\end{array}$ & $\begin{array}{l}\text { No. of } \\
\text { partici- } \\
\text { pants }\end{array}$ & Statistical method & Effect size \\
\hline 2 Total mortality & 2 & & Risk Ratio (M-H, Fixed, 95\% Cl) & $\begin{array}{l}\text { Totals not se- } \\
\text { lected }\end{array}$ \\
\hline $\begin{array}{l}2.1 \text { Elective radical neck dissection vs therapeutic } \\
\text { neck dissection ( } 1 \text { year) }\end{array}$ & 1 & & Risk Ratio (M-H, Fixed, 95\% Cl) & $0.0[0.0,0.0]$ \\
\hline $\begin{array}{l}\text { 2.2 Elective supraomohyoid neck dissection } \\
\text { (SOH) neck dissection vs therapeutic neck dissec- } \\
\text { tion ( } 3.5 \text { years) }\end{array}$ & 1 & & Risk Ratio (M-H, Fixed, 95\% Cl) & $0.0[0.0,0.0]$ \\
\hline $\begin{array}{l}3 \text { New disease, progression or mortality (HR for } \\
\text { disease-free survival) }\end{array}$ & 3 & & Hazard Ratio (Random, 95\% Cl) & Subtotals only \\
\hline $\begin{array}{l}3.1 \text { Elective radical neck dissection vs therapeutic } \\
\text { radical neck }\end{array}$ & 2 & & Hazard Ratio (Random, 95\% Cl) & $0.73[0.25,2.11]$ \\
\hline $\begin{array}{l}3.2 \text { Elective SOH neck dissection vs therapeutic } \\
\text { neck dissection ( } 3.5 \text { years) }\end{array}$ & 1 & & Hazard Ratio (Random, 95\% Cl) & $0.32[0.12,0.84]$ \\
\hline 4 New disease, progression or mortality & 2 & & Risk Ratio (M-H, Fixed, 95\% Cl) & $\begin{array}{l}\text { Totals not se- } \\
\text { lected }\end{array}$ \\
\hline $\begin{array}{l}4.1 \text { Elective radical neck dissection vs therapeutic } \\
\text { neck dissection ( } 1 \text { year) }\end{array}$ & 1 & & Risk Ratio (M-H, Fixed, 95\% Cl) & $0.0[0.0,0.0]$ \\
\hline $\begin{array}{l}4.2 \text { Elective radical neck dissection vs therapeutic } \\
\text { radical neck dissection ( } 3 \text { years) }\end{array}$ & 1 & & Risk Ratio (M-H, Fixed, 95\% Cl) & $0.0[0.0,0.0]$ \\
\hline 5 Locoregional recurrence & 4 & & Risk Ratio (M-H, Fixed, 95\% Cl) & $\begin{array}{l}\text { Totals not se- } \\
\text { lected }\end{array}$ \\
\hline $\begin{array}{l}5.1 \text { Elective radical neck dissection vs therapeutic } \\
\text { neck dissection ( } 1 \text { year) }\end{array}$ & 1 & & Risk Ratio (M-H, Fixed, 95\% Cl) & $0.0[0.0,0.0]$ \\
\hline $\begin{array}{l}5.2 \text { Elective SOH neck dissection vs therapeutic } \\
\text { neck dissection ( } 3.5 \text { years) }\end{array}$ & 1 & & Risk Ratio (M-H, Fixed, 95\% Cl) & $0.0[0.0,0.0]$ \\
\hline $\begin{array}{l}5.3 \text { Elective selective neck dissection vs therapeu- } \\
\text { tic neck dissection }\end{array}$ & 1 & & Risk Ratio (M-H, Fixed, 95\% Cl) & $0.0[0.0,0.0]$ \\
\hline $\begin{array}{l}5.4 \text { Elective radical neck dissection vs therapeutic } \\
\text { radical neck dissection ( } 3 \text { years) }\end{array}$ & 1 & & Risk Ratio (M-H, Fixed, 95\% Cl) & $0.0[0.0,0.0]$ \\
\hline
\end{tabular}

Analysis 1.1. Comparison 1 Elective neck dissection (ND) versus therapeutic (delayed) neck dissection, Outcome 1 Total mortality (HR for overall survival).

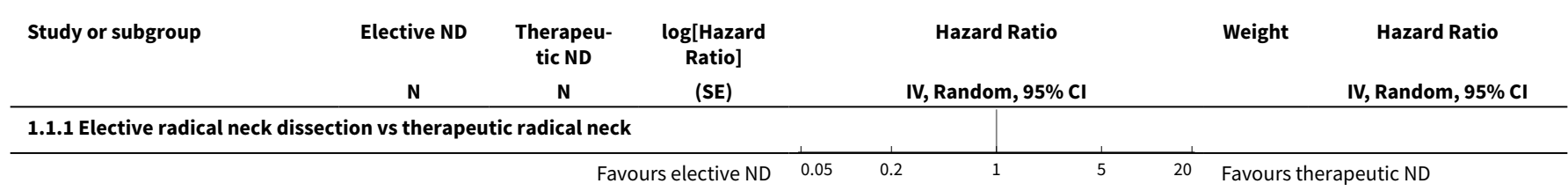




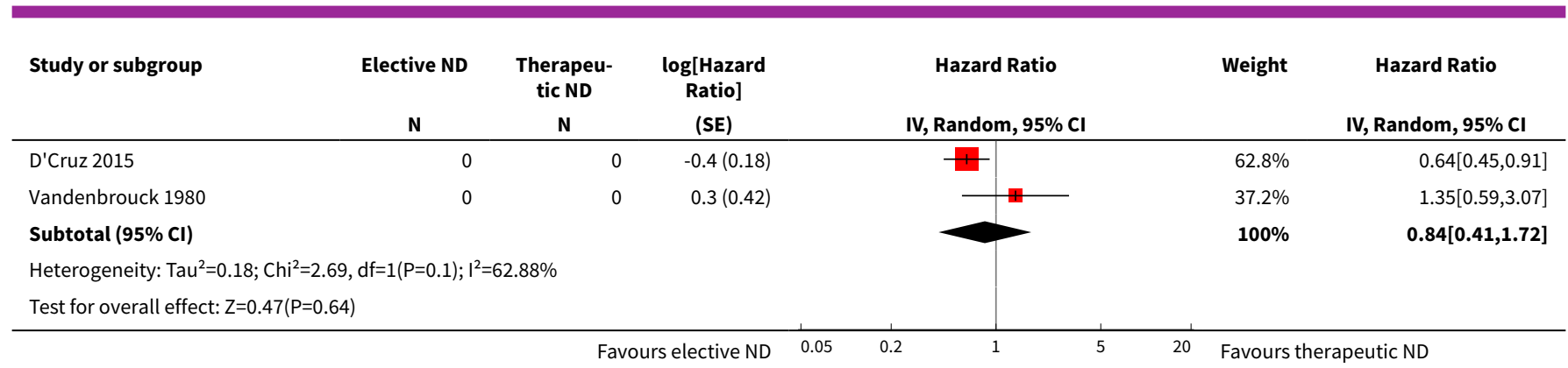

Analysis 1.2. Comparison 1 Elective neck dissection (ND) versus therapeutic (delayed) neck dissection, Outcome 2 Total mortality.

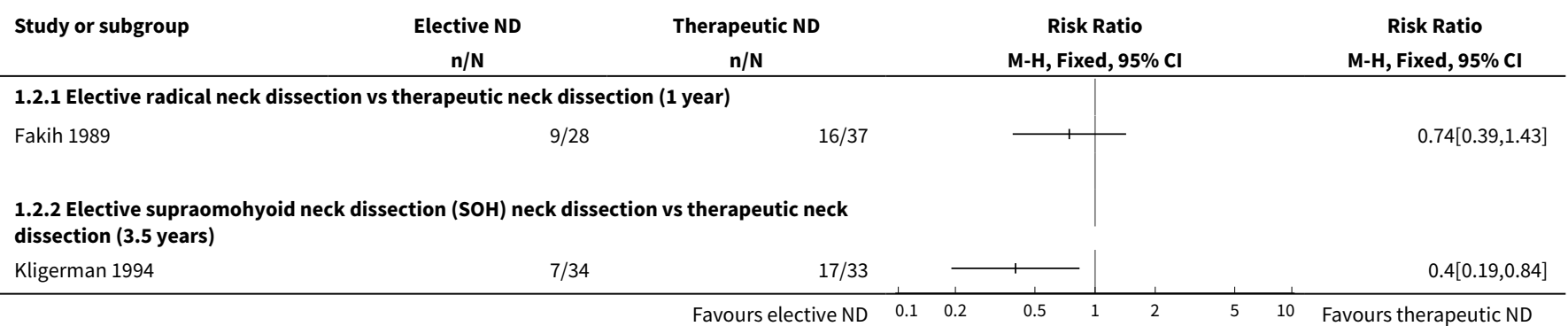

\section{Analysis 1.3. Comparison 1 Elective neck dissection (ND) versus therapeutic (delayed) neck} dissection, Outcome $3 \mathrm{New}$ disease, progression or mortality (HR for disease-free survival).

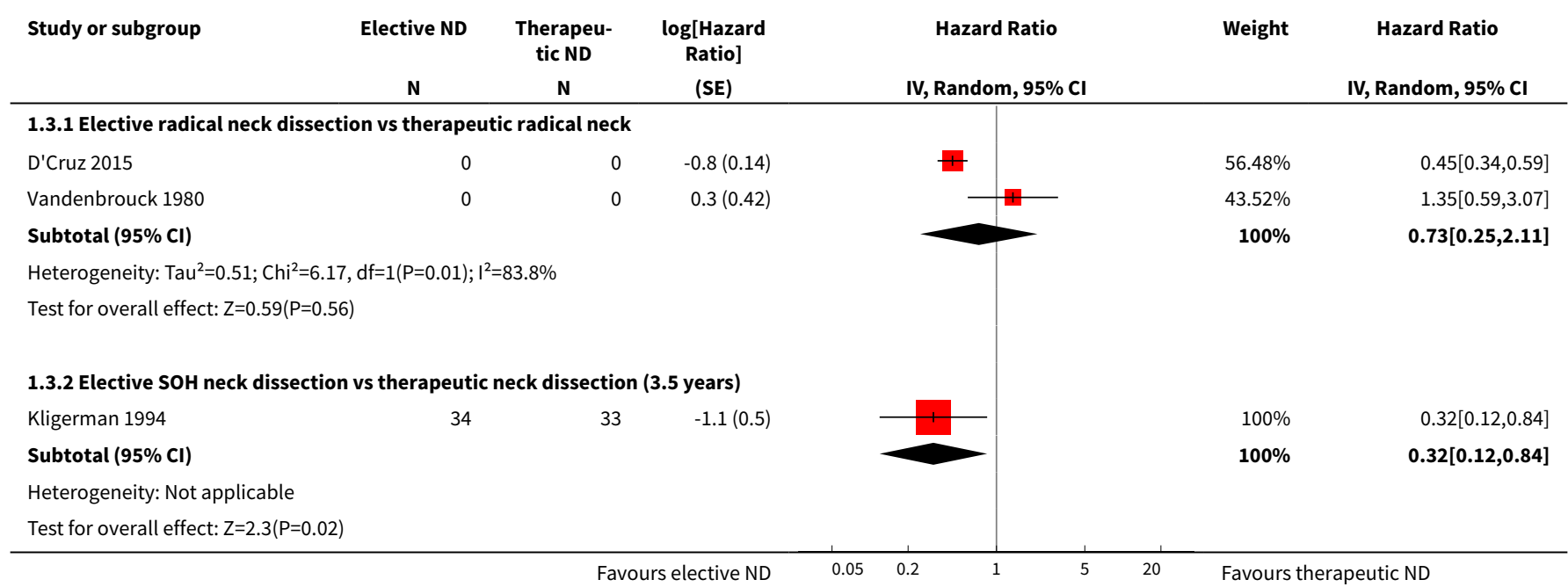


Analysis 1.4. Comparison 1 Elective neck dissection (ND) versus therapeutic (delayed) neck dissection, Outcome 4 New disease, progression or mortality.

Study or subgroup

Elective ND

$$
\mathbf{n} / \mathbf{N}
$$

Therapeutic ND

Risk Ratio

Risk Ratio

1.4.1 Elective radical neck dissection vs therapeutic neck dissection (1 year)

Fakih 1989

$19 / 28$

$$
n / N
$$

M-H, Fixed, $95 \% \mathrm{Cl}$

1.4.2 Elective radical neck dissection vs therapeutic radical neck dissection (3 years)

Analysis 1.5. Comparison 1 Elective neck dissection (ND) versus therapeutic (delayed) neck dissection, Outcome 5 Locoregional recurrence.

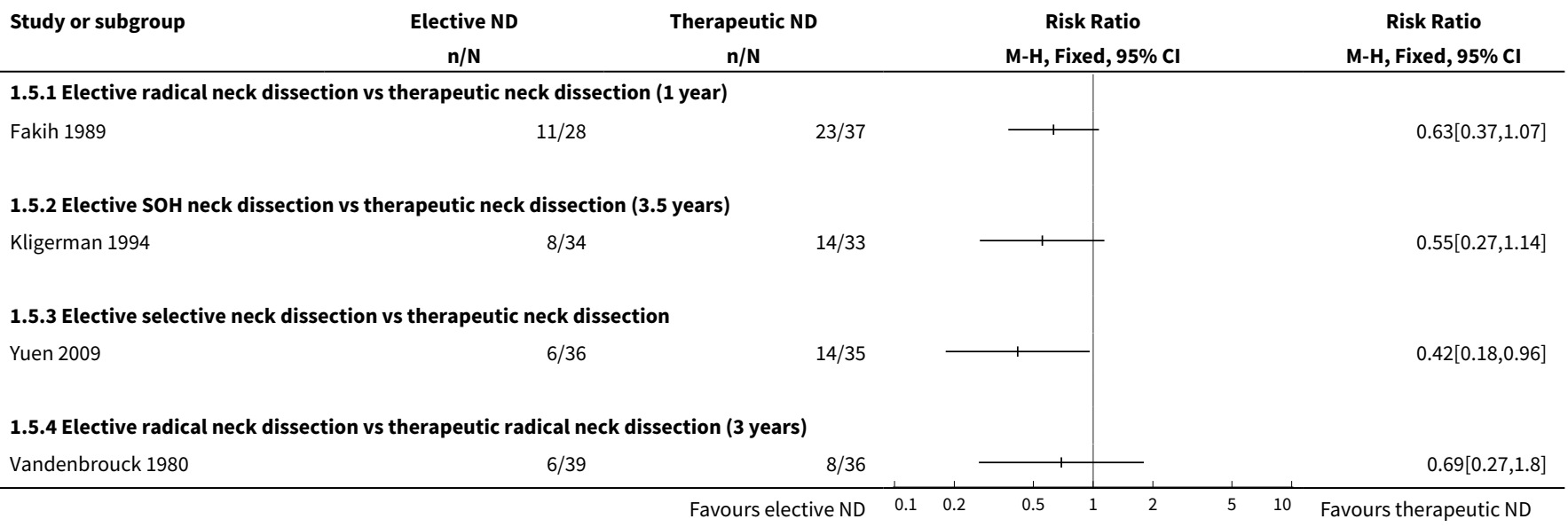

\begin{tabular}{|c|c|c|c|c|}
\hline Outcome or subgroup title & $\begin{array}{l}\text { No. of } \\
\text { studies }\end{array}$ & $\begin{array}{l}\text { No. of } \\
\text { partici- } \\
\text { pants }\end{array}$ & Statistical method & Effect size \\
\hline 1 Total mortality (HR for overall survival) & 2 & & Hazard Ratio (Fixed, 95\% Cl) & $\begin{array}{l}\text { Totals not select- } \\
\text { ed }\end{array}$ \\
\hline $\begin{array}{l}\text { 1.1 Modified radical classical neck dissection } \\
\text { (MRND) vs supraomohyoid neck dissection } \\
\text { (SOH) }\end{array}$ & 1 & & Hazard Ratio (Fixed, 95\% Cl) & $0.0[0.0,0.0]$ \\
\hline $\begin{array}{l}\text { 1.2 Radical neck dissection vs selective neck dis- } \\
\text { section }\end{array}$ & 1 & & Hazard Ratio (Fixed, 95\% Cl) & $0.0[0.0,0.0]$ \\
\hline $\begin{array}{l}2 \text { New disease, progression or mortality (HR for } \\
\text { disease-free survival) }\end{array}$ & 1 & & Hazard Ratio (Fixed, 95\% Cl) & $\begin{array}{l}\text { Totals not select- } \\
\text { ed }\end{array}$ \\
\hline $\begin{array}{l}\text { 2.1 Radical neck dissection vs selective neck dis- } \\
\text { section }\end{array}$ & 1 & & Hazard Ratio (Fixed, 95\% Cl) & $0.0[0.0,0.0]$ \\
\hline
\end{tabular}

\section{Comparison 2. Radical neck dissection (ND) versus selective neck dissection}




\begin{tabular}{lllll}
\hline Outcome or subgroup title & $\begin{array}{l}\text { No. of } \\
\text { studies }\end{array}$ & $\begin{array}{l}\text { No. of } \\
\text { partici- } \\
\text { pants }\end{array}$ & Statistical method & Effect size \\
\hline 3 Recurrence & 1 & Risk Ratio (M-H, Fixed, 95\% Cl) & $\begin{array}{l}\text { Totals not select- } \\
\text { ed }\end{array}$ \\
\hline $\begin{array}{l}3.1 \text { Resection + elective supraomohyoid dissec- } \\
\text { tion vs resection alone (5 years) }\end{array}$ & 1 & Risk Ratio (M-H, Fixed, 95\% Cl) & $0.0[0.0,0.0]$ \\
\hline
\end{tabular}

Analysis 2.1. Comparison 2 Radical neck dissection (ND) versus selective neck dissection, Outcome 1 Total mortality (HR for overall survival).

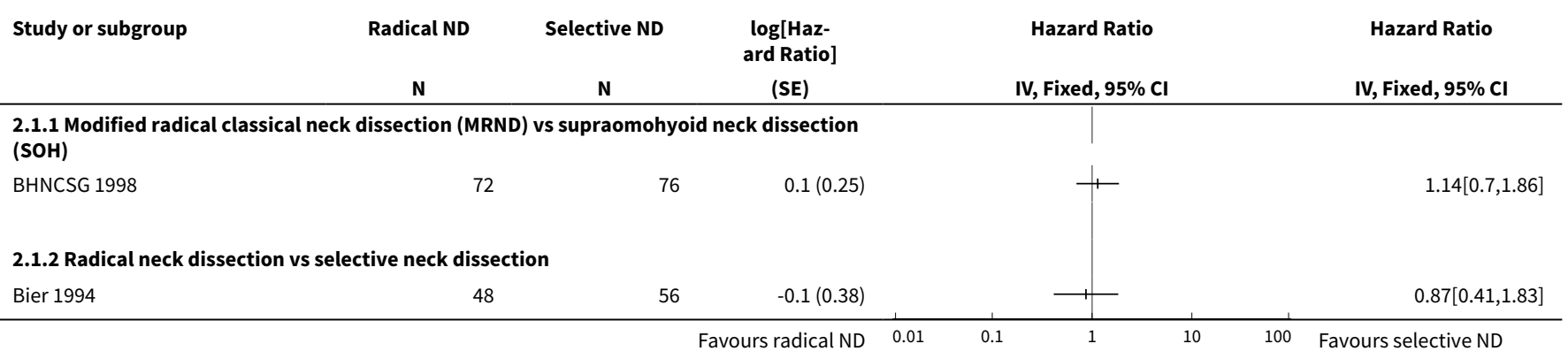

Analysis 2.2. Comparison 2 Radical neck dissection (ND) versus selective neck dissection, Outcome 2 New disease, progression or mortality (HR for disease-free survival).

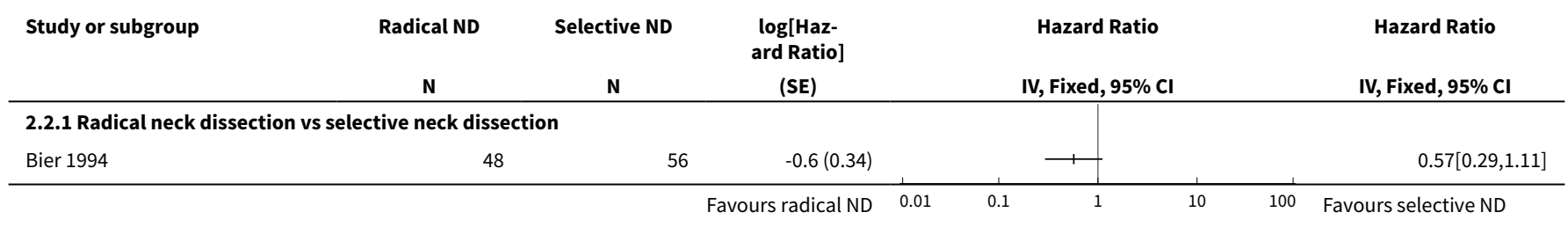

Analysis 2.3. Comparison 2 Radical neck dissection (ND) versus selective neck dissection, Outcome 3 Recurrence.

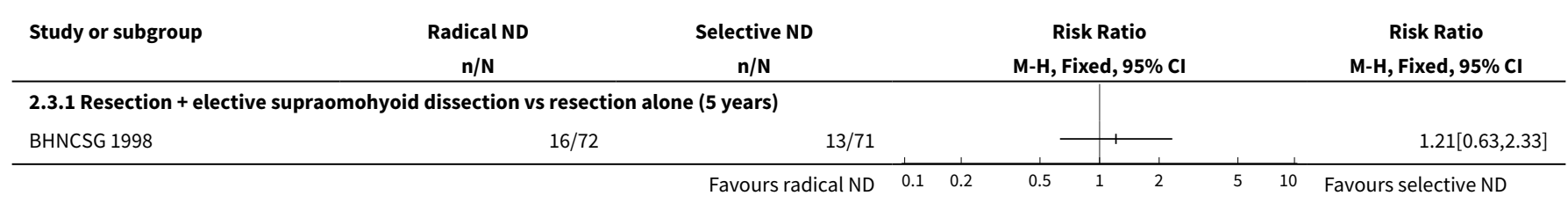


Comparison 3. Surgery plus radiotherapy (RT) versus radiotherapy alone

\begin{tabular}{lllll}
\hline Outcome or subgroup title & $\begin{array}{l}\text { No. of } \\
\text { studies }\end{array}$ & $\begin{array}{l}\text { No. of par- } \\
\text { ticipants }\end{array}$ & Statistical method & Effect size \\
\hline 1 Total mortality (HR for overall survival) & 1 & Hazard Ratio (Fixed, 95\% Cl) & Totals not selected \\
\hline
\end{tabular}

Analysis 3.1. Comparison 3 Surgery plus radiotherapy (RT) versus radiotherapy alone, Outcome 1 Total mortality (HR for overall survival).

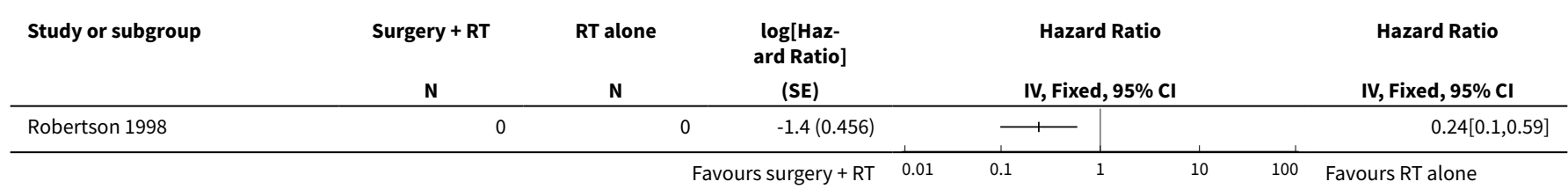

Comparison 4. Positron-emission tomography-computed tomography (PET-CT) versus planned neck dissection

\begin{tabular}{lllll}
\hline Outcome or subgroup title & $\begin{array}{l}\text { No. of } \\
\text { studies }\end{array}$ & $\begin{array}{l}\text { No. of par- } \\
\text { ticipants }\end{array}$ & Statistical method & Effect size \\
\hline 1 Total mortality (HR for overall survival) & 1 & Hazard Ratio (Random, 95\% Cl) & Totals not selected \\
\hline
\end{tabular}

Analysis 4.1. Comparison 4 Positron-emission tomography-computed tomography (PET-

CT) versus planned neck dissection, Outcome 1 Total mortality (HR for overall survival).

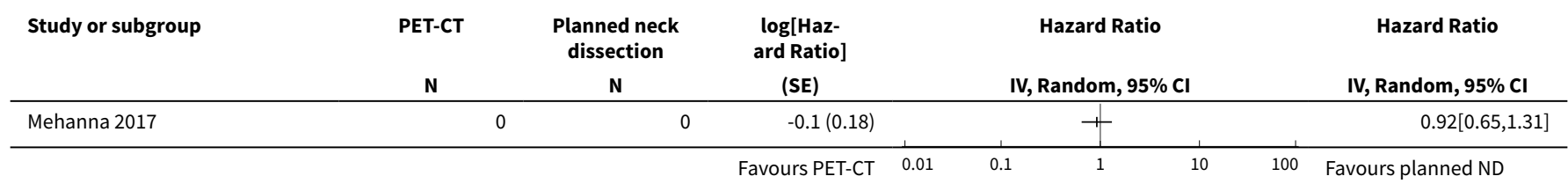

\section{ADDITIONAL TABLES}

Table 1. Stage of cancer

\begin{tabular}{lll}
\hline Study & TNM stage & Nodal status \\
\hline BHNCSG 1998 & T2 to T4 & Negative neck \\
\hline Bier 1994 & NS & Negative or positive neck \\
\hline D'Cruz 2015 & T1 or T2 & Negative neck \\
\hline Fakih 1989 & T1 or T2 & Negative neck \\
\hline
\end{tabular}


Table 1. Stage of cancer (Continued)

\begin{tabular}{lll} 
Guo 2014 & T1-T4 & Negative or positive neck \\
\hline Iyer 2015 & T3 or T4 & Negative or positive neck \\
\hline Kligerman 1994 & T1 or T2 & Negative neck \\
\hline Mehanna 2017 & T1-T4 0 N3 \\
\hline Rastogi 2018 & T1-T3 & Negative neck \\
\hline Robertson 1998 & T2-T4 & N0 to N2 \\
\hline Vandenbrouck 1980 & T1-T3 & Negative neck \\
\hline Yuen 2009 & T1 or T2 & Negative neck
\end{tabular}

NS: not stated.

\section{APPEN DICES}

\section{Appendix 1. Cochrane Oral Health's Trials Register search strategy}

1 MESH DESCRIPTOR Head and Neck Neoplasms AND INREGISTER

2 MESH DESCRIPTOR Mouth Neoplasms AND INREGISTER

3 MESH DESCRIPTOR Gingival Neoplasms AND INREGISTER

4 MESH DESCRIPTOR Palatal Neoplasms AND INREGISTER

5 MESH DESCRIPTOR Tongue Neoplasms AND INREGISTER

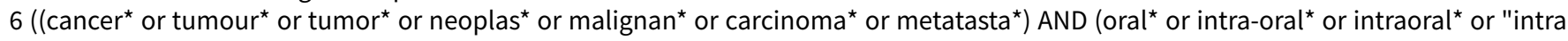

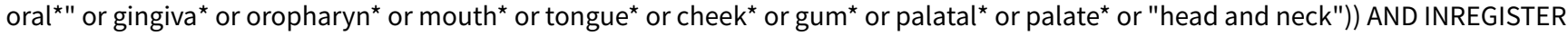

$7 \# 1$ or \#2 or \#3 or \#4 or \#5 or \#6

8 MESH DESCRIPTOR Surgical Procedures, Operative EXPLODE ALL AND INREGISTER

9 (surgery or surgical or operat*):ti,ab AND INREGISTER

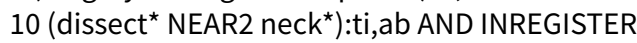

11 (excision or excise or resect $\left.{ }^{\star}\right)$ :ti,ab AND INREGISTER

12 MESH DESCRIPTOR Lymph Node Excision EXPLODE ALL AND INREGISTER

13 MESH DESCRIPTOR Oral Surgical Procedures AND INREGISTER

14 (lymphadenectom* or glossectom* or maxillectom* or micrographic or mandibulectom* or hemi-mandibulectom* or hemimandibulectom*):ti,ab AND INREGISTER

$15 \# 8$ or \#9 or \#10 or \#11 or \#12 or \#13 or \#14

16 \#7 and \#15

\section{Appendix 2. Cochrane Central Register of Controlled Trials (CENTRAL) search strategy}

1. MESH DESCRIPTOR Head and Neck Neoplasms AND CENTRAL:TARGET

2. MESH DESCRIPTOR Mouth Neoplasms AND CENTRAL:TARGET

3. MESH DESCRIPTOR Gingival Neoplasms AND CENTRAL:TARGET

4. MESH DESCRIPTOR Palatal Neoplasms AND CENTRAL:TARGET

5. MESH DESCRIPTOR Tongue Neoplasms AND CENTRAL:TARGET

6. ((cancer ${ }^{\star}$ or tumour ${ }^{\star}$ or tumor ${ }^{\star}$ or neoplas ${ }^{\star}$ or malignan ${ }^{\star}$ or carcinoma* or metatasta*) AND (oral ${ }^{\star}$ or intra-oral $^{\star}$ or intraoral ${ }^{\star}$ or $^{\star}$ "intra oral*" or gingiva* or oropharyn* or mouth* or tongue* or cheek* or gum* or palatal* or palate* or "head and neck")) AND CENTRAL:TARGET

7. \#1 or \#2 or \#3 or \#4 or \#5 or \#6

8. MESH DESCRIPTOR Surgical Procedures, Operative EXPLODE ALL AND CENTRAL:TARGET

9. (surgery or surgical or operat $\left.{ }^{\star}\right)$ :ti,ab AND CENTRAL:TARGET

10. (dissect $^{\star}$ NEAR2 neck $\left.^{\star}\right):$ ti,ab AND CENTRAL:TARGET

11.(excision or excise or resect $\left.{ }^{\star}\right):$ ti, ab AND CENTRAL:TARGET

Interventions for the treatment of oral and oropharyngeal cancers: surgical treatment (Review) 
12.MESH DESCRIPTOR Lymph Node Excision EXPLODE ALL AND CENTRAL:TARGET

13.MESH DESCRIPTOR Oral Surgical Procedures AND CENTRAL:TARGET

14.(lymphadenectom* or glossectom ${ }^{\star}$ or maxillectom* ${ }^{\star}$ or micrographic or mandibulectom* or hemi-mandibulectom ${ }^{\star}$ or hemimandibulectom*):ti,ab AND CENTRAL:TARGET

15 . \#8 or \#9 or \#10 or \#11 or \#12 or \#13 or \#14

16.\#7 and \#15

\section{Appendix 3. MEDLINE Ovid search strategy}

1 "Head and neck neoplasms"/

2 "Mouth neoplasms"/

3 "Gingival neoplasms"/

4 "Palatal neoplasms"/

5 "Tongue neoplasms"/

6 ( (cancer\$ or tumour\$ or tumor\$ or neoplas\$ or malignan\$ or carcinoma\$ or

metatasta\$) adj5 (oral\$ or intra-oral\$ or intraoral\$ or "intra oral\$" or gingiva $\$$ or oropharyn $\$$ or mouth\$ or tongue\$ or cheek\$ or gum $\$$ or palatal\$ or palate\$ or "head and neck")).mp.

7 or/1-6

8 exp Surgical procedures, operative/

9 (surgery or surgical or operat\$).mp.

10 (dissect\$ adj2 neck\$).mp.

11 (excision or excise or resect\$).mp.

12 exp Lymph node excision/

13 Oral surgical procedures/

14 (lymphadenectom\$ or glossectom\$ or maxillectom\$ or micrographic or mandibulectom\$ or hemi-mandibulectom\$ or hemimandibulectom\$).ti,ab.

15 or/8-14

167 and 15

This subject search was linked to the Cochrane Highly Sensitive Search Strategy (CHSSS) for identifying randomised trials in MEDLINE: sensitivity-maximising version (2008 revision) as referenced in Chapter 6.4.11.1 and detailed in box 6.4.c of The Cochrane Handbook for Systematic Reviews of Interventions, Version 5.1.0 (updated March 2011) (Lefebvre 2011).

1. randomized controlled trial.pt.

2. controlled clinical trial.pt.

3. randomized.ab.

4. placebo.ab.

5. drug therapy.fs.

6. randomly.ab.

7. trial.ab.

8. groups.ab.

9. or/1-8

10. exp animals/ not humans.sh.

11.9 not 10

\section{Appendix 4. Embase Ovid search strategy}

1. "Head and neck tumor"/

2. "Mouth tumor"/

3. "Gingiva tumor"/

4. "Jaw tumor"/

5. "Tongue tumor"/

6. ((cancer\$ or tumour\$ or tumor\$ or neoplas\$ or malignan\$ or carcinoma or metatasta\$) adj5 (oral\$ or intra-oral\$ or intraoral\$ or "intra oral\$" or gingiva\$ or oropharyn\$ or mouth\$ or tongue\$ or cheek\$ or gum $\$$ or palatal\$ or palate\$ or "head and neck")).ti,ab.

7. or/1-6

8. exp Oral surgery/

9. (surgery or surgical or operat\$).ti,ab.

10. (dissect\$ adj2 neck\$).ti,ab.

11. (excision or excise or resect\$).ti,ab.

12. "Lymph node dissection"/

13. (lymphadenectom\$ or glossectom\$ or maxillectom\$ or micrographic or mandibulectom\$ or hemi-mandibulectom\$ or hemimandibulectom\$).ti,ab.

14. or/8-13

Interventions for the treatment of oral and oropharyngeal cancers: surgical treatment (Review) 


\section{7 and 14}

The above subject search was linked to adapted version of the Cochrane Embase Project filter for identifying RCTs in Embase Ovid (see www.cochranelibrary.com/help/central-creation-details.html for information):

1. Randomized controlled trial/

2. Controlled clinical study/

3. Random\$.ti,ab.

4. randomization/

5. intermethod comparison/

6. placebo.ti,ab.

7. (compare or compared or comparison).ti.

8. ((evaluated or evaluate or evaluating or assessed or assess) and (compare or compared or comparing or comparison)).ab.

9. (open adj label).ti,ab.

10. ((double or single or doubly or singly) adj (blind or blinded or blindly)).ti,ab.

11. double blind procedure/

12. parallel group\$1.ti,ab.

13. (crossover or cross over).ti,ab.

14. ((assign\$ or match or matched or allocation) adj5 (alternate or group\$1 or intervention $\$ 1$ or patient $\$ 1$ or subject\$1 or participant

\$1)).ti,ab.

15. (assigned or allocated).ti,ab.

16. (controlled adj7 (study or design or trial)).ti,ab.

17. (volunteer or volunteers).ti,ab.

18. trial.ti.

19. or/1-18

20. (exp animal/ or animal.hw. or nonhuman/) not (exp human/ or human cell/ or (human or humans).ti.)

21. 19 not 20

\section{Appendix 5. US National Institutes of Health Ongoing Trials Register (ClinicalTrials.gov) search strategy}

Advanced search: "oral cancer" AND surgery

Limited to interventional studies

\section{Appendix 6. World Health Organization International Clinical Trials Registry Platform search strategy}

Advanced search: oral cancer

WHAT'S NEW

\begin{tabular}{lll}
\hline Date & Event & Description \\
\hline 6 April 2020 & Amended & $\begin{array}{l}\text { Minor edit to description of GRADE in 'Summary of findings' ta- } \\
\text { bles }\end{array}$ \\
\hline
\end{tabular}

\section{H I S T O R Y}

Protocol first published: Issue 4, 2006

Review first published: Issue 4, 2007

\begin{tabular}{lll}
\hline Date & Event & Description \\
\hline 4 December 2018 & $\begin{array}{l}\text { New citation required and conclusions } \\
\text { have changed }\end{array}$ & $\begin{array}{l}\text { Conclusions for comparisons already included remain the same, } \\
\text { and have low- to very low-certainty evidence, but new compar- } \\
\text { isons have been added. }\end{array}$ \\
\hline 20 December 2017 & New search has been performed & $\begin{array}{l}\text { Search updated and five new studies included. New comparisons } \\
\text { added. New lead author and byline. }\end{array}$ \\
\hline
\end{tabular}




\begin{tabular}{lll}
\hline Date & Event & Description \\
\hline 4 July 2011 & New search has been performed & Searches updated to 17 February 2011. \\
\hline 4 July 2011 & $\begin{array}{l}\text { New citation required and conclusions } \\
\text { have changed }\end{array}$ & $\begin{array}{l}\text { Two new trials added. New comparisons, and conclusions. } \\
\text { Twenty-four previously included trials now moved to other oral } \\
\text { cancer reviews on chemotherapy and radiotherapy. }\end{array}$ \\
\hline 28 April 2009 & Amended & Minor changes to the data. \\
\hline 20 June 2008 & Amended & Converted to new review format. \\
\hline
\end{tabular}

\section{CONTRIBUTIONS OFAUTHORS}

- VB and HW co-ordinated and managed the review update.

- The trials search strategy was refined with input from VB. (It was designed by Cochrane Oral Health Information Specialist Anne Littlewood.)

- HW, VB, AMG, DC and MM screened the titles and abstracts.

- HW organised retrieval of papers.

- HW and VB screened retrieved papers against the inclusion criteria.

- VB, HW and AMG extracted data, appraised the risk of bias in the included studies, and assessed the certainty of the body of evidence for each main comparison and outcome.

- HW and AMG provided a methodological perspective.

- DC, MM and JC provided a clinical perspective.

\section{DECLARATIONS OF INTEREST}

VB: none known.

HW: none known. I am a Co-ordinating Editor of Cochrane Oral Health.

AMG: none known. I am Deputy Co-ordinating Editor of Cochrane Oral Health.

JC: none known. I am a Co-ordinating Editor of Cochrane Oral Health.

DC: none known.

MM: none known.

\section{SOURCES OF SUPPORT}

\section{Internal sources}

- The School of Dentistry, The University of Manchester, Manchester Academic Health Sciences Centre (MAHSC) and the NIHR Manchester Biomedical Research Centre, UK.

- The University of Dundee, UK.

- The University of Glasgow, UK.

\section{External sources}

- Cochrane Oral Health Global Alliance, Other.

The production of Cochrane Oral Health reviews has been supported financially by our Global Alliance since 2011 (oralhealth.cochrane.org/partnerships-alliances). Contributors over the past year have been the American Association of Public Health Dentistry, USA; AS-Akademie, Germany; the British Association for the Study of Community Dentistry, UK; the British Society of Paediatric Dentistry, UK; the Canadian Dental Hygienists Association, Canada; the Centre for Dental Education and Research at All India Institute of Medical Sciences, India; the National Center for Dental Hygiene Research \& Practice, USA; New York University College of Dentistry, USA; and the Swiss Society for Endodontology, Switzerland.

- National Institute for Health Research (NIHR), UK.

This project was supported by the NIHR, via Cochrane Infrastructure funding to Cochrane Oral Health. The views and opinions expressed herein are those of the review authors and do not necessarily reflect those of the Systematic Reviews Programme, the NIHR, the NHS or the Department of Health.

- National Institutes of Health, National Institute of Dental \& Craniofacial Research, USA. 
- Central Manchester \& Manchester Children's University Hospitals NHS Trust, UK.

\section{DIFFERENCES BETWEEN PROTOCOL AND REVIEW}

This section includes changes that have been made since the previous iterations of the review as well as from protocol.

Types of interventions: the intervention under evaluation must have been surgery. We excluded trials where all participants received the same surgical regimen and were randomised to other treatments.

Outcomes: local regional control was renamed as locoregional recurrence.

Search methods: the search strategy was updated.

It was considered more appropriate to use random-effect models for any pooling of studies.

The original quality assessment approach was replaced by use of the Cochrane 'Risk of bias' tool (Higgins 2011).

We updated the data synthesis section. The primary outcome that was most reliably and frequently reported was total mortality expressed as a hazard ratio. For dichotomous outcomes, we expressed the estimates of effect of an intervention as RRs with $95 \%$ confidence intervals. Dichotomous data were only used for primary outcomes where hazard ratios were unavailable or could not be calculated.

We performed no subgroup analyses for this update.

\section{INDEX TERMS}

\section{Medical Subject Headings (MeSH)}

*Lymph Node Excision [methods] [mortality]; Disease Progression; Disease-Free Survival; Elective Surgical Procedures [methods] [mortality]; Mouth Neoplasms [mortality] [ ${ }^{\star}$ surgery]; Oropharyngeal Neoplasms [mortality] [ ${ }^{\star}$ surgery]; Randomized Controlled Trials as Topic

\section{MeSH check words}

Humans 